ALÉM DO CORPO: UMA EXPERIÊNCIA EM ARTE/EDUCAÇÃO

\title{
ANA AMÁLIA TAVARES BASTOS BARBOSA
}

SÃO PAULO

2012 


\title{
UNIVERSIDADE DE SÃO PAULO
}

Escola de Comunicação e Artes

\section{ALÉM DO CORPO: UMA EXPERIÊNCIA EM ARTE/EDUCAÇÃO}

\author{
ANA AMÁLIA TAVARES BASTOS BARBOSA
}

Tese apresentada ao Programa de Pós-Graduação em Artes Área de Concentração Artes Plásticas, Linha de Pesquisa Teoria Ensino e Aprendizagem, da Escola de Comunicação e Artes da Universidade de São Paulo como exigência parcial para obtenção do titulo de Doutora em Artes, sob orientação da prof. Dra Regina Stela Barcelos Machado.

SÃO PAULO 
Comissão Julgadora

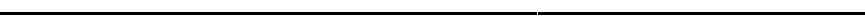




\section{AGRADECIMENTOS}

Não é possível agradecer individualmente tantas foram as pessoas que me ajudaram, direta ou indiretamente. Portanto obrigada a minha família, aos meus amigos, aos médicos e terapeutas, a minha orientadora e a todos que aguentaram meu stress. 
Um sistema que parecia ter já se fixado - o sistema da arte- entra numa nova lógica, mais abrangente, mais pública, numa fase mais expansiva do que restritiva, irrestritamente inclusiva... E qualquer que seja a leitura, sob qualquer parâmetro, inclusive esta, só pode ser ambivalente e provisória. Ainda dependente da confirmação histórica e só dela.

PAULO VENÂNCIO FILHO 


\section{RESUMO}

Este estudo analisa o trabalho de Artes Visuais desenvolvido durante três anos, de 2008 a 2010 com seis crianças que tiveram paralisia cerebral e outras lesões cerebrais no nascimento. As crianças tinham entre 7, 8 e 9 anos na época. O objetivo principal das aulas de arte foi o de desenvolver os sistemas proprioceptivo e exteroceptivo. O sistema proprioceptivo é definido como a percepção do corpo no espaço e da relação dos segmentos do corpo entre eles. O sistema exteroceptivo é definido como a ação dos sentidos da visão, audição, sensibilidade da pele, cheiro e sabor. Desenvolvi um projeto que trabalhou a relação do corpo no espaço mas ao mesmo tempo era voltado especificamente para o desenvolvimento da percepção, tentando envolver todos os sentidos.. Outra preocupação foi a inclusão cultural dessas crianças levando-os para exposições e espaços culturais. O desenvolvimento da consciência corporal e da alfabetização cultural estava associado não só com a visita a instituições culturais, mas também com a apresentação de obras de artistas e a presença de artistas convidados para trabalhar com eles na sala de aula.Começamos com o desenho do contorno dos corpos em papel, pintura e fotografia.Continuamos usando o corpo, desta vez como um pincel, depois de assistirmos ao vídeo de Yves Klein, no qual as bailarinas com corpos pintados produziam pinturas na tela com seus corpos. Continuamos, ao convidar um artista para pintar seus rostos. A relação do corpo,da cadeira de rodas e do espaço continuou sendo explorada através da visita ao Instituto Tomie Ohtake e outras visitas como ao Jardim de Esculturas do Parque da Luz e à Exposição de Arte para Crianças no SESC Pompeia, onde eles exploraram uma reinterpretação do Quadrado Mágico n.5 de Hélio Oiticica. Todas as crianças usam cadeiras de rodas, alguns não falam e têm dificuldade de ver. A professora também está em cadeira de rodas, não fala. E tem defict visual. Tinha que ir às instituições antes da visita dos estudantes para verificar a acessibilidade e a receptividade.. A preparação para as visitas também envolveu o entendimento anterior com as instituições e os seus serviços educacionais. Desde 2008 os professores da ONG Nosso Sonho, onde este estudo foi realizado, estão trabalhando para a alfabetização deste grupo de crianças. A neurobiologia considera que passada

a idade adequada para a alfabetização torna-se mais difícil aprender a ler e escrever. É necessário uma reabilitação através do desenvolvimento integrado dos sentidos. Baseei-me em varias fontes entre elas também em Hélio Oiticica para projetar as atividades para desenvolver a percepção do corpo inteiro e em John Dewey para apoiar a ideia de experiências provocadas.

Palavras-chave: Arte-Educação; paralisia cerebral; percepção. 


\begin{abstract}
This study examines the work of visual arts developed during three years from 2008 to 2010 with six children who had cerebral palsy and other brain injuries at birth. Children were 7, 8 or 9 at the time. The main objective of art classes was to develop the proprioceptive and exteroceptive systems. The proprioceptive system is defined as the perception of body in space and of body segments in relationship. Exteroceptive system is defined as the action of the senses of sight, hearing, skin sensitivity, smell and taste. I developed a project that worked the body's relationship in space and specifically focused on the development of perception, trying to involve all the senses..Another concern was the cultural inclusion of these children taking them to exhibitions and cultural spaces. The development of body awareness and sense of cultural literacy was associated with not only visiting cultural institutions, but also the presentation of works by artists and the presence of guest artists to work with them in the classroom. We begin with contour drawing of the bodies on paper, painting, and photography. We continue using the body, this time, as a brush after seeing the video of Yves Klein where dancers with painted bodies produced paintings on the screen. We continue inviting an artist to paint their faces. The relationship of the body with other bodies, the weelchair, works of Art and space continued in the visit to the Instituto Tomie Ohtake and other visits to the Garden of Sculptures in the Parque da Luz and the Children's Art Exhibition at SESC Pompeia, where they explored a reinterpretation of the Magic Square 5 by Hélio Oiticica. All children use wheelchairs, some do not speak and have difficulty to see. The teacher is also in wheelchair, does not speak and has visual problems. So I had to go to the institutions before the students to check the accessibillity. The preparation for the visits also involved the previous understanding with the institutions and their educational services. Since 2008 the teachers of the NGO Nosso Sonho (Our Dream) where this study took place,are working towards the literacy of this group of children. The neurobiology considers that the lost of appropriate age for literacy, makes it more difficult to learn to read and write.It is necessary a rehabilitation through the integrated development of the senses. I relied also on Hélio Oiticica to project activities to develop the whole body perception and John Dewey to support the idea of provoked experiences.
\end{abstract}

Key words: Art Education; cerebral palsy, perception. 


\section{SUMÁRIO}

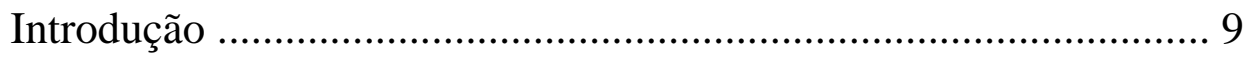

Capítulo 1 - Como surgiu a pesquisa? Como eu vejo

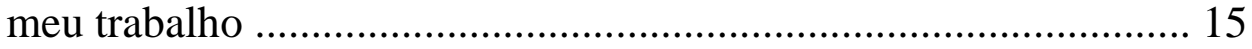

Capítulo 2 - Como os outros veem meu trabalho e

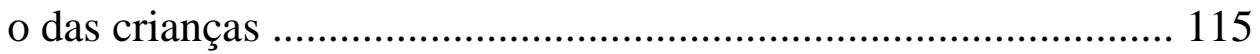

Capítulo 3 - Quase conclusão .................................................... 128

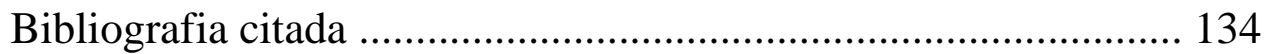




\section{INTRODUÇÃO}

Antes de começar, quero deixar claro que, apesar de meus alunos terem paralisia cerebral, ou melhor, dizendo, terem lesões cerebrais, ou mais modernamente falando encefalopatia congênita, não sou arte terapeuta, não faço e nem pretendo fazer arte terapia, sou arte/educadora e o que eu faço é arte/educação. Mas, acredito que todo fazer artístico tem função terapêutica como o leitor poderá concluir ao longo do desenvolvimento dessa tese.

Com Umbertina Conti Reed (1997, p. 305) aprendi que o "quadro motor sequelar da paralisia cerebral varia num mesmo individuo quanto à natureza semiológica e quanto à intensidade". A autora ressalta o fato das lesões não serem progressivas, o que é um elemento facilitador da educação.

Em Arte /Educação vislumbrei a possibilidade de trabalhar com o que Nitrini (1997, p. 12) chama de receptores sensoriais também apoiada, em Susanne Langer (1980) que considera os sentidos os órgãos da mente.

Para Nitrini há três sistemas de sensibilidade: proprioceptivo, exteroceptivo, interperceptivo, que ele define da seguinte maneira.

Os sistemas exteroceptivos, são responsáveis pela sensibilidade a estímulos externos e incluem a visão, audição, a sensibilidade cutânea, o olfato e o paladar. Os sistemas proprioceptivos relacionam-se às noções de posição do corpo no espaço e dos segmentos do corpo em relação aos demais. Os sistemas interoceptivos responsabilizam se pela sensibilidade a estímulos provenientes de vísceras, vasos sanguíneos e outras estruturas internas. (NITRINI, 1997, p. 12)

Um dos objetivos que determinei para meu trabalho foi estimular a sensibilidade proprioceptiva e a sensibilidade exteroceptivas. Comecei a trabalhar com as crianças a partir do corpo no espaço. (sensibilidade proprioceptiva) A minha própria experiência comprovava a importância do reconhecimento do corpo em relação ao espaço.

Quando voltei a pintar um dos meus primeiros trabalhos foi um autoretrato. O meu médico o Dr. Ayres Teixeira, que procura sempre me estimular, me fez ficar em pé amarrada em uma cama ortostática frente a um espelho na vertical, para que eu me visse inteira. Ele me dizia: olhe seu corpo não se move, mas você tem corpo, você não é só cabeça. 
Realmente! Eu posso não mexe-lo, mas tenho corpo. A cadeira é um instrumento, e não a extensão do meu corpo. não foi o primeiro profissional a me fazer encarar o espelho, mas foi "quando deu o clic". Eu tinha que estimular as percepções sensorial, corporal e espacial nas crianças. Elas precisam ter domínio do próprio corpo, apesar de ele ser manipulado por outros. Esse é o principio da autonomia!

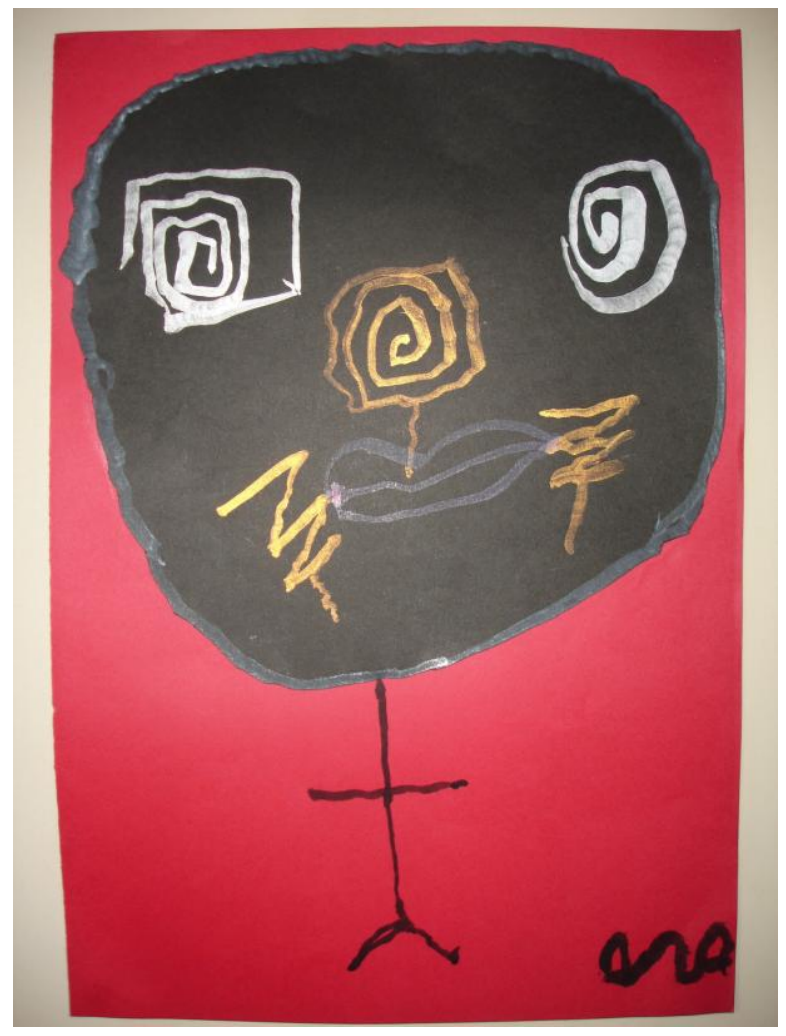

Autoretrato de Ana Amália 2006

Esta experiência em relação a negação de meu próprio corpo coincidiu com o inicio do trabalho com as crianças. Uma das primeiras atividades que projetei para elas não era nenhuma novidade metodológica, mas aprendi com a Abordagem Triangular (Barbosa, 1992, Barbosa e Cunha, 2010) que na experiência da arte na educação não é a novidade que temos que priorizar, mas o contexto, e as necessidades do grupo com o qual se trabalha.

Pedi para colocarem um rolo de papel Kraft no chão e propus as crianças deitarem sobre o papel enquanto seus cuidadores desenhavam o contorno de seus corpos no papel, depois recortálos e pintá-los e por fim construir cenas com esta, na qual a representação de seus corpos se interrelacionam uns com os outros, dialogam, brincam, exploram o espaço como não podem fazê-lo 
na vida real, pois estão presos a cadeiras de rodas. Através da representação e da imaginação eles vão além das limitações que lhes são impostas.

Carmela Gross (Barbosa, 1984, p. 110) já havia trabalhado com o contorno dos corpos dos alunos em uma atividade na Pinacoteca do Estado nos anos 80, quando era diretor Fábio Magalhães. A diferença é que as crianças desenhavam o contorno dos corpos umas das outras, o que as crianças com quem eu trabalho não podem fazer.

Portanto para, uma percepção mais aguda do corpo no espaço acrescentamos o trabalho de criação de diferentes cenas com os desenhos dos corpos das crianças. Foi uma atividade muito prazerosa e divertida para eles e também valiosa para desenvolver a relação uns com os outros e com o espaço.

A ida ao Instituto Tomie Ohtake para verem, perceberem o movimento de seus corpos e da cadeira de rodas, instrumentalização de seus corpos, em relação ao espaço expositivo e ao movimento das esculturas de Tomie Ohtake, assim como a ida ao Parque da Luz também foram guiadas pelo mesmo objetivo, desenvolvimento da sensibilidade proprioceptiva para mobilizar a mente, ampliar o campo de referencias e estimular o interesse cultural.

Recentemente houve um grande retorno ao estudo do desenho em relação ao desenvolvimento para investigar a forma de relacionamento intercerebral que o desenho provoca.

Nos dias 28 a 30 de outubro de 2011 houve no Departamento de Arte/Educação do Teachers College da Columbia University, onde estudei e com o qual me mantenho em comunicação um encontro de pessoas que pesquisam o desenho como forma de pensamento. Estão criando na Inglaterra um robô que seja capaz de demonstrar as funções cerebrais que um desenho mobiliza. Um dos trabalhos feitos neste encontro foi deitar as pessoas em papel Kraft como eu fiz com as crianças, e propor que eles desenhassem com as duas mãos ao redor de si mesmos sem se levantar, só desenhar até aonde seus braços e mãos tivesse alcance ao redor de si mesmos.

O objetivo era outro, mostrar como as soluções gráficas variam de individuo para individuo. A pesquisa com o robô é muito complexa para dar conta desta diversidade.

Portanto, uma mesma atividade proposta também varia de acordo com a diversidade dos objetivos a serem atingidos tornando-se uma outra atividade, semelhante apenas na forma.

Outros trabalhos como o brincar com as cores foram programados para estimular a sensibilidade exteroceptiva, responsável pela captação de estímulos externos que incluem a visão, audição, a sensibilidade cutânea, o olfato e o paladar. 
É muito difícil determinar a amplitude da cognição, da capacidade de aprender de crianças que nasceram com paralisia cerebral. O sistema escolar tende a rejeita-los ou a abandona-los na sala de aula. Pelo que aprendi com Jerome Bruner e Elliot Eisner, cujos livros não cito pois os li antes do AVC, ou melhor AVE, e minha biblioteca foi roubada por quem ficou em minha casa, que a melhor atitude pedagógica é alternar atividades muito simples com outras de mais alta complexidade pois a capacidade cognitiva da criança filtra aquilo que pode aprender.

Eu garantia a mobilização cognitiva com as atividades muito simples, como colocar cores diferentes com um pincel no papel uma experiência que todos podiam processar,porém com a ida aos espaços culturais proporcionava experiências mais complexas que não sabia até onde nem o que eles poderiam processar.A ideia era garantir o mínimo e ousar o máximo, nunca nivelar por baixo com a desculpa de que eles não entendem.

$\mathrm{Na}$ videografia internacional há vários documentários de mães lutando para que as autoridades escolares reconheçam que seus filhos com paralisia cerebral têm capacidade de aprender mesmo se não conseguem falar. O mais impressionante deles é o As autoridades estão sempre certas apresentado no Festival Assim Vivemos de 2009 no CCBB de São Paulo que mostra a luta da mãe de um menino que teve paralisia cerebral ao nascer para matriculá-lo em uma escola inglesa de crianças normais. Seu filho fora encaminhado para uma escola de deficientes mentais. Quando consegue vencer juridicamente, depois de anos a decisão chega tarde, o menino acabara de morrer.

O site E-HOW procura mostrar o que devem os professores saberem sobre a Paralisia Cerebral. Neste site Dr Greene no artigo "Cerebral Palsy Source: Teaching" diz que 75\% das crianças com paralisia cerebral tem inteligência normal. Ele menciona relatos de mães, como a mãe que é entrevistada no vídeo inglês acima mencionado,demonstrando que há enorme dificuldade em se aceitar que eles podem aprender. Minha mãe tem esta experiência. Mesmo pessoas eruditas a olham com piedade quando ela afirma que eu tenho a cognição e a memória perfeitas. A próxima pergunta do interlocutor é quase sempre: Ela entende o que eu digo?....pronunciado com evidente incredulidade.

Uma recomendação que o Dr. Greene faz é que nunca devemos presumir que uma criança com paralisia cerebral não pode fazer ou entender alguma coisa.

"Many times the child will surprise you with what they can indeed accomplish, despite disabilities". 
Ele acrescenta que a maior parte das crianças com paralisia cerebral, pode se desempenhar tão bem ou possivelmente melhor do que estudantes de capacidade média. Como muitas vezes eles não podem fala, como a maioria dos meus alunos, ficam impossibilitados de facilmente demonstrar suas capacidades cognitivas.

Outros podem lutar mais por causa de déficits mentais, mas eles devem ser encorajados a atingir altas expectativas também. Bibliografia consultada na internet no endereço http://www.ehow.com/about_5266377_should-teachers-cerebral-palsy.html

Acessado no dia 07/11/2011 às 14:15.

Outro dos meus objetivos foi a ampliação do campo cultural dos alunos como já me referi anteriormente. A Pedagogia vem dando muita ênfase ao desenvolvimento cultural como fator propiciador do desenvolvimento cognitivo com bases em Vygotsky, Paulo Freire e outros culturalistas.

A "privação cultural" vem sendo apontada como uma das causas das dificuldades de aprendizagem. Meus alunos tem dificuldade de locomoção, seus pais trabalham e tem pouco tempo para levá-los a entretenimento e espaços culturais. São pais com uma sobrecarga enorme de trabalho doméstico e de responsabilidades pessoais e econômicas. Para vencer a "privação cultural" e assim ampliar o desenvolvimento cognitivo não é necessário apenas expô-los a cultura, mas levá-los a pensar sobre ela, a se conscientizarem dos valores culturais aos quais são expostos.

Isto é tarefa da escola que deve se constituir em um laboratório de experiências.

No site Le Sueur Consultoria e Cursos a Distância encontrei um texto sobre o trabalho de Reuve Feuerstein com crianças orfãs dos campos de concentração nazistas depois da segunda guerra mundial. Infelizmente o texto não tem autor nem bibliografia mas diz categoricamente, "Feuerstein (1997) rompe com os paradigmas de que a idade e fatores orgânicos como a herança genética, anomalias cromossômicas, emocionais, sejam impeditivos para a modificabilidade cognitiva e afetiva, sejam irreversíveis e a causa central da falta de aprendizagem. Gomes (2002).” http://www.cursosadistancia.pro.br/teorias_aplicadas/cursos_a_distancia_reuven_feuerstein.htm. Acessado dia 15/12/2011 às 16:16.

Realmente Feuerstein vem trabalhando há muitos anos com mediação cultural ou com a consciencia cultural como fator gerador de desenvolvimento cognitivo, como pesquisador e diretor do Internacional Center for the Enhancement of Learning Potencial em Jerusalém. No site citado há um relato atribuido a Feuerstein 
Durante a Segunda Guerra, vivi em campos de concentração e depois em prisões nazistas. A guerra acabou e dediquei-me às crianças sobreviventes do holocausto. Elas foram para Israel depois de passarem três, quatro anos nos campos de concentração. Seus pais haviam morrido em câmaras de gás. Algumas chegaram em Israel como esqueletos. Eram totalmente analfabetas aos oito,nove anos de idade. Eu não podia aceitar que fossem retardadas ou idiotas. Passei mais de sete anos trabalhando com essas crianças. Não conseguiam organizar o pensamento, nem suas ações. Uma noite, em Jerusalém, um dos meninos, com oito anos, deitou-se ao meu lado e então começamos a ler filosofia juntos. A mudança era possível. Feuerstein http://www.cursosadistancia.pro.br/teorias_aplicadas/cursos_a_distancia_reuven_feuerstein.htm

Este é o relato de um caso extremo de privação cultural e de todos os direitos humanos, mas a Pedagogia Cultural (David Trend,1992) baseada em Paulo Freire e Henry Giroux vem demostrando no cotidiano escolar a força da cultura conscientizada para o desenvolvimento da cognição. 


\section{CAPITULO 1}

\section{COMO SURGIU A PESQUISA? COMO EU VEJO MEU TRABALHO}

Em meados de 2007, como parte do meu tratamento de reabilitação junto à terapia ocupacional no Instituto de Medicina Física e de Reabilitação IMREA do Hospital das Clinicas HC da Faculdade de Medicina da Universidade de São Paulo FMUSP, antiga DMR, Divisão de Medicina de Reabilitação, comecei a ministrar oficinas de arte. Eram adultos com alguma deficiência física.

Eu preparava a aula por escrito, imprimia uma copia para cada aluno e levava. O professor responsável que me acompanhava lia junto com os alunos, eles pegavam o material e trabalhavam, no fim olhávamos todos os trabalhos, eu levantava algumas questões, mostrava a obra de algum artista e conversávamos.

Eu não imaginava que seria possível retomar a docência afinal eu estava tetraplégica e muda a convivência com os alunos, foi uma reviravolta na minha vida. Como não posso comer usava uma sonda nasoenteral que me dava aspecto de doente. Depois das oficinas que dei no IMREA fiz a gastrostomia para poder tirar a sonda naso-enteral e retomar um aspecto mais saudável.

Na mesma época me inscrevi para o doutorado na Escola de Comunicações e Artes da Universidade de São Paulo CA/USP. Meu projeto era muito amplo, mas já incluía a pesquisa atual.

No inicio de 2008, a Marisa Hirata (terapeuta ocupacional que me atende desde 2004) e a Suely Katz (gerente da ONG Nosso Sonho) me chamaram para lecionar arte a um grupo de seis crianças, três meninos e três meninas, na Associação Nosso Sonho. São crianças na pré alfabetização, cadeirantes, todos com déficit visual e de força muscular, tetraparesicos sendo um diparetico, cinco crianças são mudas, as quais foram diagnosticadas com paralisia cerebral, uma é hidrocefalica, duas tiveram anoxia de parto, uma delas sequela de bilirrubina, outra sequela de toxoplasmose, e um prematuro e gêmeo.

Fiquei em pânico, mas extremamente desafiada. Afinal, tanto a faixa etária (na época em que iniciamos elas tinham 7,8 ou 9 anos, hoje são pré-adolescentes)quanto a paralisia cerebral me eram totalmente desconhecidas. Estudei, respirei fundo e aceitei. O meu médico Dr Ayres Teixeira me deu uma bibliografia sobre disfunções cerebrais. Dessa bibliografia o que mais me ajudou foi o livro de Ricardo Nitrini,A Neurologia que todo médico deve saber (1997). 
No começo eu dava aula acompanhada da arte terapeuta, da terapeuta ocupacional e da coordenadora pedagógica. Aos poucos elas foram me deixando só com a professora. Não me apavoro mais, tenho meus artifícios como a buzina (que eu aciono com a cabeça e que eu uso pra que prestem atenção a algo). Paralelamente, eu estava cursando as disciplinas do doutorado e o projeto foi sendo alterado até chegar no projeto que deflagrou o trabalho com as crianças que apresento aqui.

Trata-se de pesquisação colaborativa, com a participação de especialistas das diversas áreas da escola, especialmente da professora de classe. Associei à pesquisação a Arts Based Research in Art Education, abordagem metodológica lançada por Elliot Eisner nos anos oitenta e revista nos anos dois mil por Ricardo Marin (2010) que a vem praticando com seus orientandos na Universidade de Granada, Espanha. Trata-se de pesquisa que seja explicitada através da imagem. $\mathrm{O}$ que apresento aqui é uma pesquisa cujo relato integra texto e imagem de forma a ambas as linguagens se integrarem e se completarem para o entendimento do leitor.

Algumas vezes citarei textos que escrevi no meu Blog, no calor da hora, imediatamente depois da experiência, porque dele também veio muita resposta positiva e muito estímulo nos momentos mais difíceis desta jornada em direção a um pensamento mais estruturado.

Pesquisação é pesquisa qualitativa e sua qualidade essencial é a transparência da subjetividade do pesquisador.

No exame de qualificação me perguntaram onde eu estava, dando a entender que eu devia mostrar mais integralmente minha ideias e circunstancias, não apenas o resultado do trabalho com os alunos. Agradeço a critica e espero não ter exagerado me expondo excessivamente, além dos limites estabelecidos pela academia. À primeira vista meu trabalho atual não tem relação com minha pesquisa anterior de mestrado, que foi sobre a interdisciplinaridade possível entre o ensino de inglês e ensino de arte. Minha pesquisa agora não é a interdisciplinaridade de conteúdo, mas, introjetei a interdisciplinaridade como atitude definida por Ivaní Fazenda (1994):

uma atitude diante de alternativas para conhecer mais e melhor, atitude de espera ante os atos consumados, atitude de reciprocidade que impele à troca, que impele ao diálogo - ao diálogo com pares anônimos ou consigo mesmo, atitude de humildade diante da limitação do próprio saber, atitude de perplexidade ante a possibilidade de desvendar novos saberes, atitude de desafio - desafio perante o novo, desafio em redimensionar o velho - Atitude de envolvimento e comprometimento com os projetos e com as pessoas neles envolvidos atitude, pois, de compromisso em construir sempre da melhor forma possível, atitude de respon- 
sabilidade mas, sobretudo, de alegria, de revelação, de encontro, enfim de vida". (FAZENDA, 1994, p. 31.)

Minha experiência de retornar a ensinar Arte depois de cinco anos de mudez e tetraplegia como, resultado de um AVC de tronco cerebral foi fundamental para a reabilitação da identidade perdida de professora que marcou minha vida desde os 15 anos de idade, quando dava aulas de Arte nas praças de São Paulo com um grupo de professoras da Secretaria de Educação do Estado de São Paulo em um projeto de Educação Popular Aquelas eram aulas para crianças nos tempos do modernismo expressionista em Arte/Educação bem diferentes das aulas que eu planejava para a oficina de artes do IMREA mais informadas culturalmente e mais contextualizadas.

Como já disse, no IMREA eu preparava a aula e levava escrito para os alunos, o professor responsável já sabia por e-mail do que se tratava e providenciava o material com antecedência. Os alunos eram adultos com algum déficit motor, sequelas menos severas que as minhas e a dos alunos com quem convivo hoje. A seguir algumas aulas no IMREA:

\section{OBSERVAÇÃO}

VAMOS TENTAR OLHAR TUDO QUE NOS RODEIA DE FORMA DIFERENTE, COMECEMOS COM UM OBJETO COMUM, O PREGADOR DE ROUPA.

ANTES DE DESENHAR, PEGUEM UM PREGADOR E SINTA O PESO, A TEXTURA E VEJA COMO ELE FUNCIONA. AGORA, COM UM LAPIS, DESENHE, DETALHADAMENTE, UM PREGADOR. VC TEM 5 MINUTOS.

MUDE A POSIÇÃO DO PREGADOR E DESENHE DENOVO, AGORA VC TEM 1 MINUTO.

MUDE A POSIÇÃO E DESENHE MAIS UMA VEZ. AGORA VC TEM 30 SEGUNDOS.

AGORA DESENHEM, NOVAMENTE, POR 5 MINUTOS. 
OLHEM OS DESENHOS DOS OUTROS.

VAMOS CONVERSAR UM POUCO:

-VC JA TINHA VISTO UM PREGADOR DE ROUPA?

-QUANTAS VEZES VC OLHOU ATENTAMENTE PARA UM PREGADOR DE ROUPA?

-QUE OUTROS OBJETOS OU PESSOAS VC GOSTARIA DE OLHAR DE UM JEITO DIFERENTE?

\title{
VARIOS ARTISTAS TRABALHARAM A PARTIR DE OBJE- TOS COMUNS. O ARTISTA QUE EU ESTOU MOSTRANDO EH APENAS UM.
}

\author{
ANA AMALIA \\ $26 / 09 / 07$
}

Apresentava então a obra de Claes Oldenburg que eu introduzia assim:

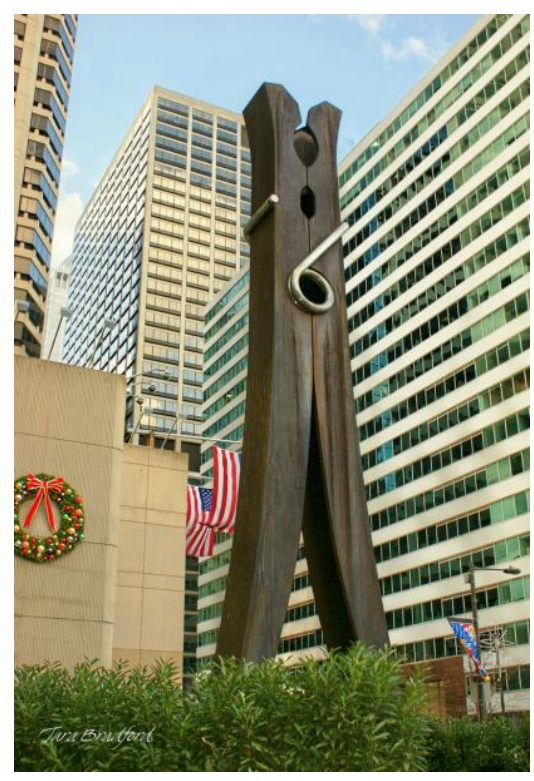

Depois de estimular a observação de um objeto de uso cotidiano, um dos mais baratos no mercado de utilitários domésticos, busquei impulsionar a imaginação: 


\title{
VCS JAH FIZERAM DESENHO DE OBSERVAÇÃO E DE MEMORIA DOS PREGADORES.
}

\author{
TEM UM ARTISTA, O CLAES OLDENBURG, QUE FEZ UMA \\ ESCULTURA GIGANTE DE UM PREGADOR. \\ E VC O QUE FARIA? USE SUA IMAGINAÇÃO E CRIE UM \\ DESENHO EM QUE APAREÇAM PREGADORES. USE COR SE \\ QUISER, E TODO O ESPAÇO DO PAPEL.
}

\author{
ANA AMÁLIA \\ $31 / 10 / 2007$.
}

Estas oficinas me fizeram re-acreditar no poder organizador da arte para mim e para os adultos com quem trabalhei.

Fiquei tão entusiasmada que propus um projeto de desenho para todos os usuários da piscina do IMREA. Segundo Mauricio Koprowski Garcia diretor da hidroterapia do IMREA,que introduziu no Brasil o método Halliwick:

Mais de mil pessoas com deficiência foram atendidas pelo Projeto Halliwick na piscina da unidade Lapa do IMREA desde sua implantação há 4 anos.

O controle da respiração, do equilíbrio e dos movimentos na água são os principais objetivos do Método. As atividades são elaboradas levando-se em consideração a habilidade de cada grupo, portanto o programa inclui todos, independentemente de sua deficiência.

Com apoio da Associação Halliwick Internacional e Associação Brasil Halliwick este é um projeto pioneiro no Brasil. Foram mais de 68 mil atendimentos e inúmeros benefícios aos usuários, exclusivamente pessoas com deficiência. (Mauricio Koprowski Garcia em depoimento a Ana Amália Barbosa em 2008)

Mauricio Koprowski Garcia é não só muito competente mas muito cuidadoso com os pacientes. Quando minha mãe desesperadamente procurava hidroterapia para mim e fui recusada em todos os lugares, inclusive na AACD, ela ligou para o então Secretario de Estado da Saúde, Dr Barradas, que garantiu que em quinze dias iria conseguir o melhor hidroterapeuta do Brasil para mim. 
Era Maurício Koprowski Garcia que acabava de ser contratado por Dra Linamara Batistella para o IMREA, naquele tempo chamado DMR. Realmente Maurício é o melhor profissional que eu poderia ter encontrado. Ele e Moacir Simplício meu colega e amigo de todas as horas foram os principais colaboradores do projeto de desenho e júri do processo de avaliação e escolha.

O tema era "Como você se sente estando na piscina". Nós, a totalidade dos usuários das piscinas do IMREA não temos piscina em casa. Para mim estar na água é uma libertação. Meu corpo torna-se tão leve que qualquer membro pode ser manipulado a vontade do terapeuta.

Ao contrario, fora da água minha mãos se fecham a ponto de doerem muito e para alguém dobrar minha perna muitas vezes é impossível. As aplicações de toxina botulínica melhoram muito as dores, mas a piscina é potencializadora dos efeitos positivos da toxina botulínica. Imaginava que outros usuários como eu tinham na piscina uma fonte de prazer.

Entregamos a cada usuário papel sulfite A4, um lápis HB2, borracha e estojo de lápis de cera com cores primárias para levarem para casa, pois pensei também em estimular que continuassem a trabalhar autonomamente com desenho. Chegaram quase 150 desenhos. Os participantes haviam sido avisados que haveria um júri para seleção dos desenhos que iriam fazer parte de um grande painel, impresso em plotagem e material plástico e exibido "pro tempore" na piscina da sede da Lapa. A seleção dos trabalhos foi realizada tomando como base critérios artísticos previamente determinados pelo júri. Classificamos em três grupos; GRUPO 1: Desenhos mais expressivos, menos estereotipados e mais pessoais; GRUPO 2: Desenhos que apenas respondem nossa pergunta e GRUPO 3: Desenho de usuários que mandaram mais de um desenho, que não responde nossa pergunta, ou que apenas descrevem o espaço.

$\mathrm{Na}$ inauguração do painel na Lapa estavam presentes os participantes, suas famílias, o júri, Dra Linamara Batistella, Secretária das Pessoas com Deficiência do Governo do Estado de São Paulo e sua equipe e até o Secretário de Estado da Saúde, Dr Barradas, um grande incentivador dos meios de Reabilitação propostos pela Dra Linamara. Foi muito estimulante.

Quando no início de 2008 a Marisa Hirata Terapeuta Ocupacional me propôs levar a experiência de Arte para uma classe do Nosso Sonho eu estava muito estimulada pelo trabalho que o IMREA me levou a fazer para minha própria reabilitação.

Marisa justificou sua indicação e descreveu a minha atividade da seguinte maneira: 


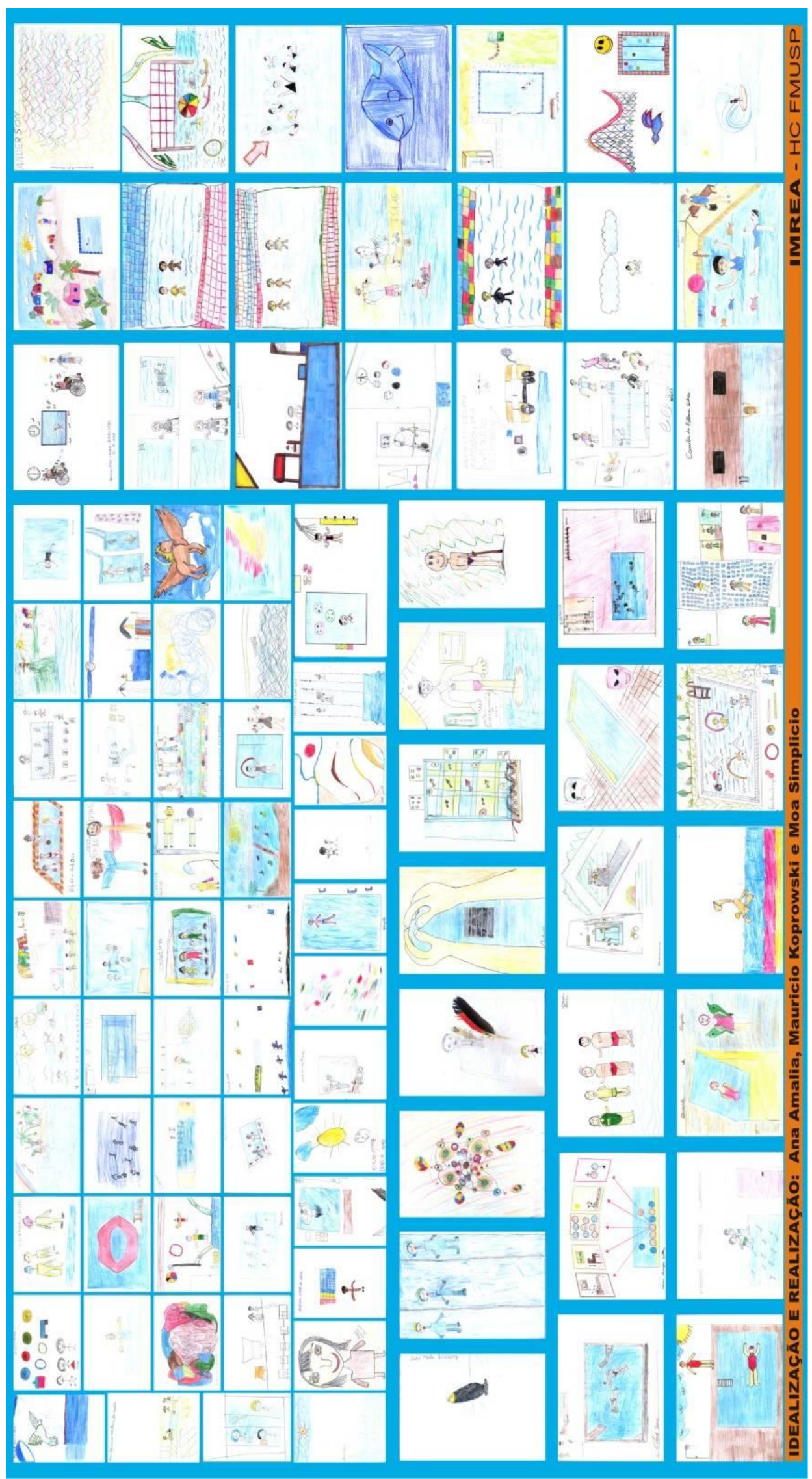


Quando no início de 2008 a Marisa Hirata Terapeuta Ocupacional me propôs levar a experiência de Arte para uma classe do Nosso Sonho eu estava muito estimulada pelo trabalho que o IMREA me levou a fazer para minha própria reabilitação.

Marisa justificou sua indicação e descreveu a minha atividade da seguinte maneira:

“O trabalho da terapia ocupacional iniciado com Ana Amália Barbosa em setembro/2004 baseou-se no retorno às atividades como artista plástica propondo adaptações para viabilizar maior autonomia. A avaliação motora sugeriu o uso do queixo para realização da pintura, concomitantemente a base (mesa) necessitou de ajustes para melhor percepção do espaço e controle do pincel. Sua evolução motora caminhou junto com suas perspectivas enquanto artista plástica, possibilitando a proposta de reinserção no mercado de trabalho, não em intensidade que lhe permita a sobrevivência econômica, pois isto seria impossível, mas que lhe permita se sentir útil na sociedade.

Crianças com paralisia cerebral com comprometimento motor e bom nível de compreensão foram beneficiadas com seu trabalho. Ana Amália contou com outros profissionais para execução do seu trabalho. A terapia ocupacional teve uma participação mais efetiva no início através da indicação e elaboração das adaptações dos materiais utilizados pelos alunos e também nas alterações da proposta de trabalho para que houvesse maior participação dos alunos.

O resultado foi evidenciando não só a nível gráfico como também no aspecto afetivo, emocional e motor. "É visível o interesse e a atenção de cada aluno, mesmo aqueles com déficit visual e observou-se a evolução das crianças mais comprometidas motoramente, não somente nas aulas de artes como também no desempenho de outras atividades". Depoimento de Marisa Hirata a Ana Amália Barbosa em junho de 2011.

No dia do convite para dar aula na Associação Nosso Sonho escrevi no blog através do qual me comunico com os amigos que restaram e os novos que muito me estimulam, mas que não tem tempo para um constante contato presencial:

29/01/2008

HOJE DE MANHÃ FUI À ASSOCIAÇÃO NOSSO SONHO. FUI CONHECER O GRUPO DA EDUCAÇÃO INFANTIL, SÃO CRIANÇAS LINDAS E COM PARALISIA CEREBRAL, UM DESAFIO E 
TANTO! LEMBREI DE QUANDO COORDENAVA OS MEDIADORES DA EXPOSIÇÃO DO CASTELO RA-TIM-BUM. SEMPRE QUE VINHA UM GRUPO DE CRIANÇAS DA A.A.C.D., EU DAVA UM JEITO DE SUMIR. EU NÃO QUERIA ASSUMIR MINHA IGNORÂNCIA. HOJE EM DIA ADICIONO A ISSO, UM MEDO, GIGANTESCO, DE FRUSTA-LOS.

NA DMR FAZ PARTE DO MEU TRATAMENTO, E EH MAIS FACÍL COM ADULTOS. (http://amaliabarbosa.zip.net)

Resolvi começar pelas cores e pelo expressionismo abstrato (vide power point em cd anexo) pensando no desenvolvimento da percepção visual que é parte do sistema exteroceptivo.

Depois de conhecer as crianças, suas dificuldades e potencialidades resolvi começar pelos movimentos mais simples, que todos pudessem executar e pela cor que percebi que os encantava. Contava com um certo receio deles para pegar no pincel, na tentação de por a mão na tinta, mas pensei no que Ana Lia (minha filha) gosta e deve aprender em termos de arte, ela adora tinta e papel colorido (é claro que também é para me imitar), outra coisa da qual ela gosta é de ouvir a história do artista.

Para começar eu era acompanhada pela Marisa Hirata terapeuta ocupacional, pela Cecília arte/terapeuta, pela professora Cristiane e sua assistente Tamires da Silva Oliveira, que hoje é a professora da classe e pela Sandra Carabetti orientadora pedagógica que tempos depois escreveu a respeito o texto avaliativo que está transcrito no segundo capítulo.

Hoje em dia sou só eu, Tamires e sua assistente na sala de aula.

COMO EH QUE EU DOU AULA?

EIS A PERGUNTA QUE TODOS SE FAZEM, AFINAL UMA PROFESSORA TETRA AINDA DAH PRA IMAGINAR, MAS MUDA??? NO INICIO EU FAZIA UM PLANEJAMENTO MENSAL, 
NÃO MUITO DETALHADO E NÃO ME DIRIGIA ÀS CRIANÇAS DIRETAMENTE, HOJE EU FAÇO UM PLANEJAMENTO MAIS GERAL E DEPOIS, ALGUNS DIAS ANTES DA AULA, ENVIO MINHA CARTA/ROTEIRO NELA EU EXPLICO DETALHADAMENTE PARA AS CRIANÇAS O QUE E COMO FAZER E COMO SERAH A PARTICIPAÇÃO DA TAMIRES. ELA PROVIDENCIA O MATERIAL E SE PREPARA. LEVO A CARTA/ROTEIRO IMPRESSA E A TAMIRES, AO MEU LADO, LE PARA AS CRIANÇAS. ENQUANTO TRABALHAM EU INTERFIRO, TOCANDO A BUZINA, E A TAMIRES SABE USAR MINHA COMUNICAÇÃO, EU DIGO À ELA E ELA FALA PARA AS CRIANÇAS. COM A CONVIVÊNCIA NEM TUDO PRECISA SER DITO. O QUE ME IMPRESSIONA EH QUE ENQUANTO NOS COMUNICAMOS AS CRIANÇAS ESPERAM CALMAMENTE E FICAM ATENTAS. (http://amaliabarbosa.zip.net)

Como já disse no primeiro semestre trabalhamos com as cores primárias e secundárias e vimos as obras de Arshile Gorky, Philip Guston e Clyfford Still. (vide o cd em anexo)
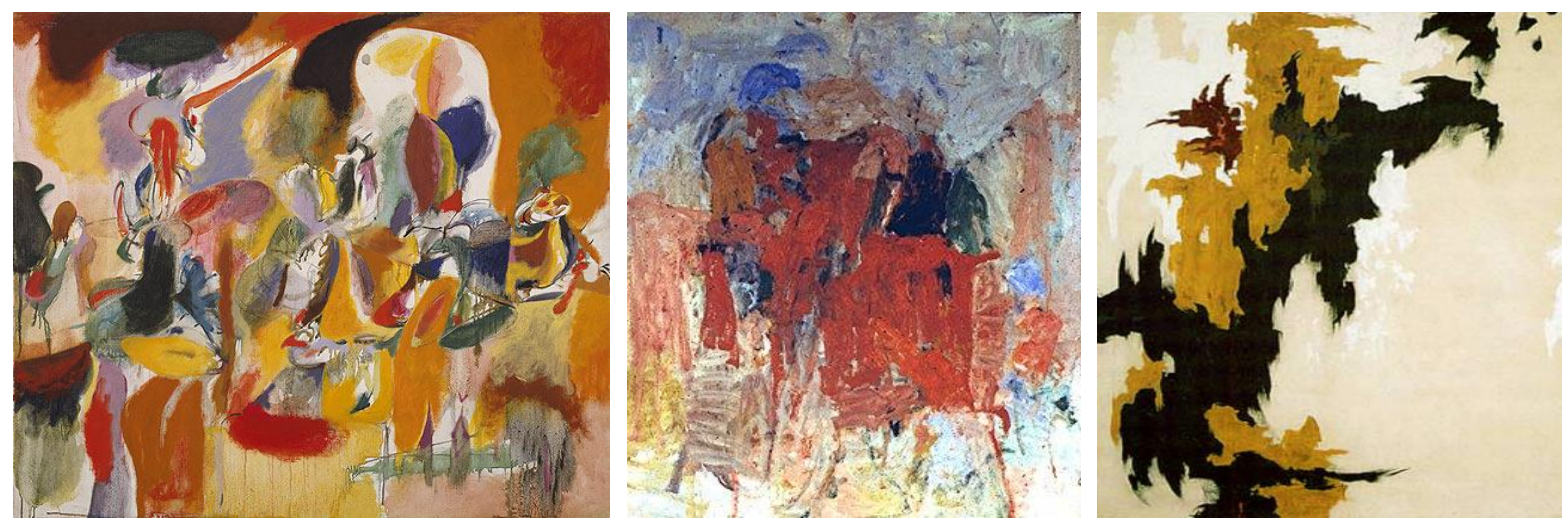
Quando eu comecei a lecionar no Colégio Equipe nos idos de 1986, Ausonia Donato uma professora que trabalha com educação e com saúde também, muito mais experiente do que eu, me disse que para ser professor é preciso saber, saber ser e saber ser professor. No começo, nem eu nem as crianças sabíamos como "ser". Era uma situação totalmente nova para todos nós, mas mesmo sem o verbal nós nos entendemos. Quando eu chego, eles veem de longe a cadeira com um adulto e sabem que sou eu, a maioria me recebe sorrindo.

Esses são os trabalhos finais do primeiro semestre:
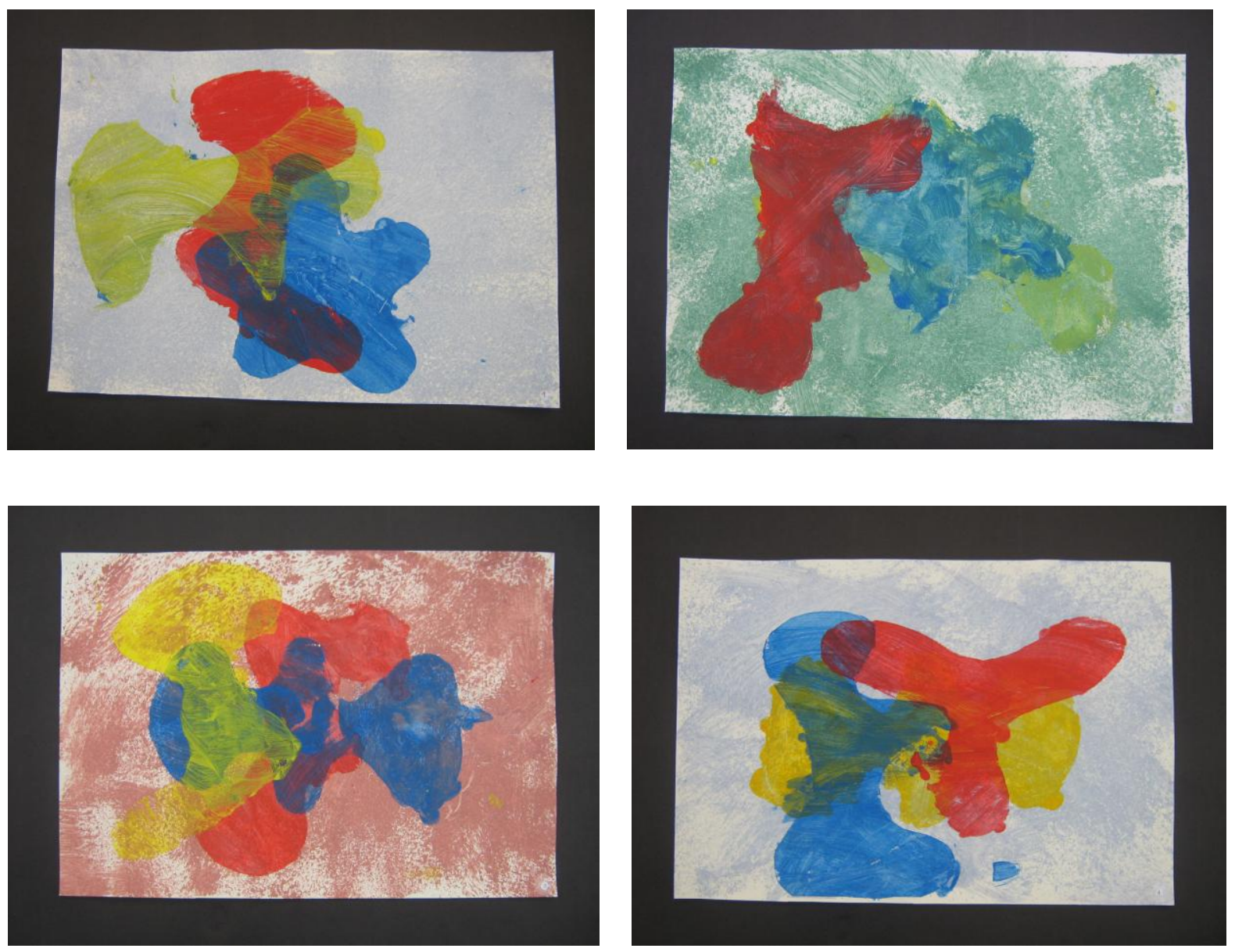

$29 / 03 / 2008$

A AULA SOBRE EXPRESSIONISMO ABSTRATO FOI ÓTIMA, MAS ASSIM COMO O PPT SOBRE O MATISSE, (ESSE FOI UM POWER POINT QUE EU FIZ, PARA MEUS ALUNOS ADULTOS, SOBRE 
OS RECORTES DO MATISSE E COMO ELE MUDOU DE MEDIA, MAS CONTINUOU PRODUZINDO APESAR DE TER SE TORNADO CADEIRANTE.) (vide o cd em anexo) ERA IMPORTANTE MOSTRAR À AQUELAS PESSOAS QUE A VIDA CONTINUA E NÃO ACABA POR ESTARMOS DEFICIENTES.O FAZER FICA PRA AULA SEGUINTE. EU TO COM O "TIMING" ERRADO. MESMO SEM PPT, AS AULAS FICAM LONGAS, EU PRECISO PENSAR MAIS NO TEMPO! (http://amaliabarbosa.zip.net)

Eu sempre me perguntava por que eu faço tanta questão de pintar de forma tradicional sendo que é fisicamente exaustivo, eu só pinto uma vez por semana com a T.O., às vezes levo mais de um mês pra terminar um desenho. Mas hoje, ao fazer o planejamento do curso pras crianças da Nosso Sonho, percebi que apesar de não poder tocar na tinta, eu sinto o cheiro da tinta, e posso sentir sua textura, temperatura, etc., e é isso que eu quero que as crianças possam sentir. O computador não permite essas sensações, mas facilita muito.

Ao mesmo tempo em que acho que as crianças só terão total autonomia pra desenhar se usarem o computador, eu também acho que elas tem o direito a experiências sensoriais diretas e necessitam delas.

A experiência ocorre continuamente, porque a interação do ser vivo com as condições ambientais está envolvida no processo de viver... Muitas vezes, porém,a experiência vivida é incipiente. As coisas são experimentadas, mas não de modo a se comporem em uma experiência singular...

Em contraste com essa experiência, temos uma experiência singular quando o material vivenciado faz o percurso até sua consecução. Então, e só então, ela é integrada e demarcada no fluxo geral da experiência proveniente de outras experiências. (JOHN DEWEY, 2010, p. 109.1 ${ }^{\text {a }}$ tradução brasileira do livro publicado em inglês em 1934).

É com as ideias de John Dewey em mente que busco provocar experiências estéticas singulares em meus alunos, sem exigir respostas imediatas além do prazer estampado em seus rostos e nos movimentos quase sempre descoordenados, mas vibrantes. 
Um autor que hoje se dedica mais a pesquisa sobre criatividade, mas que me influenciou na direção ao desenvolvimento do prazer da experiência estética foi Mihaly Csikszentmihalyi. O livro que escreveu com Rick Robinson, The Art of Seeing, deu-me estimulo para perseguir o prazer da Arte com meus alunos.

No capítulo inicial sobre o "Modelo Conceitual da Experiência Estética" eles dizem:

This study proposes to contribute to the understanding of how to make looking at works of art more enjoyable. The human organism has a variety of sensory links to its environment, each of them capable, in different ways, of providing pleasurable experiences. A man possesses nothing certainly save a brief loan of his own body, wrote James B. Cabell (1919), and yet the body of man is capable of much curious pleasure. But to translate the potential benefits of our sensory equipment into actuality, the senses must be cultivated and disciplined (Mihaly Csikszentmihalyi, 1990, p. 1)

17 DE AGOSTO DE 2008

PENSAMENTOS AVULSOS:

AFINAL, O QUE EH ARTE TERAPIA? TODO FAZER ARTÍSTICO EH TERAPEUTICO?

PENSAR SOBRE ARTE E EM COMO ENSINA-LA ME SALVOU DE UM PROVAVEL FINAL DEPRESSIVO! PQ? (http:// Amáliabarbosa.zip.net)

$23 / 08 / 2008$

\section{DIA 19 TEVE REUNIÃO DE PAIS NA “ASSOCIAÇÃO NOSSO SONHO”, NÃO CONSIGO DESCREVER O QUE SENTI. TEM SIDO IMPORTANTE! (http://amaliabarbosa.zip.net)}

No segundo semestre de 2008 trabalhamos o corpo como instrumento e suporte. A primeira atividade foi contornar nossos corpos, desenhando-os no papel, depois, usando tabelas de cores, criadas por eles, pintamos por partes (cabeça, braços, mãos, tronco, pernas e pés). 

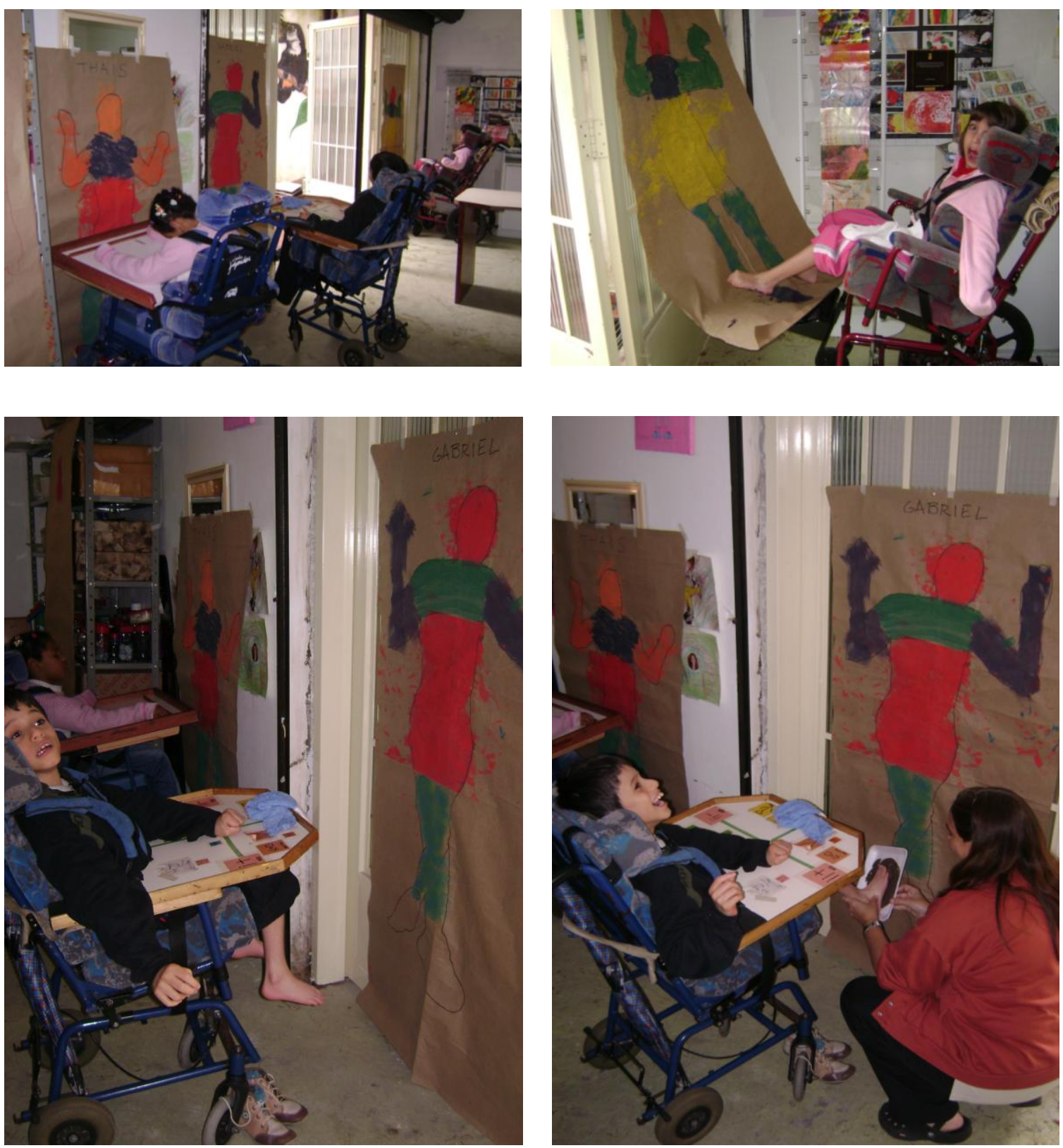

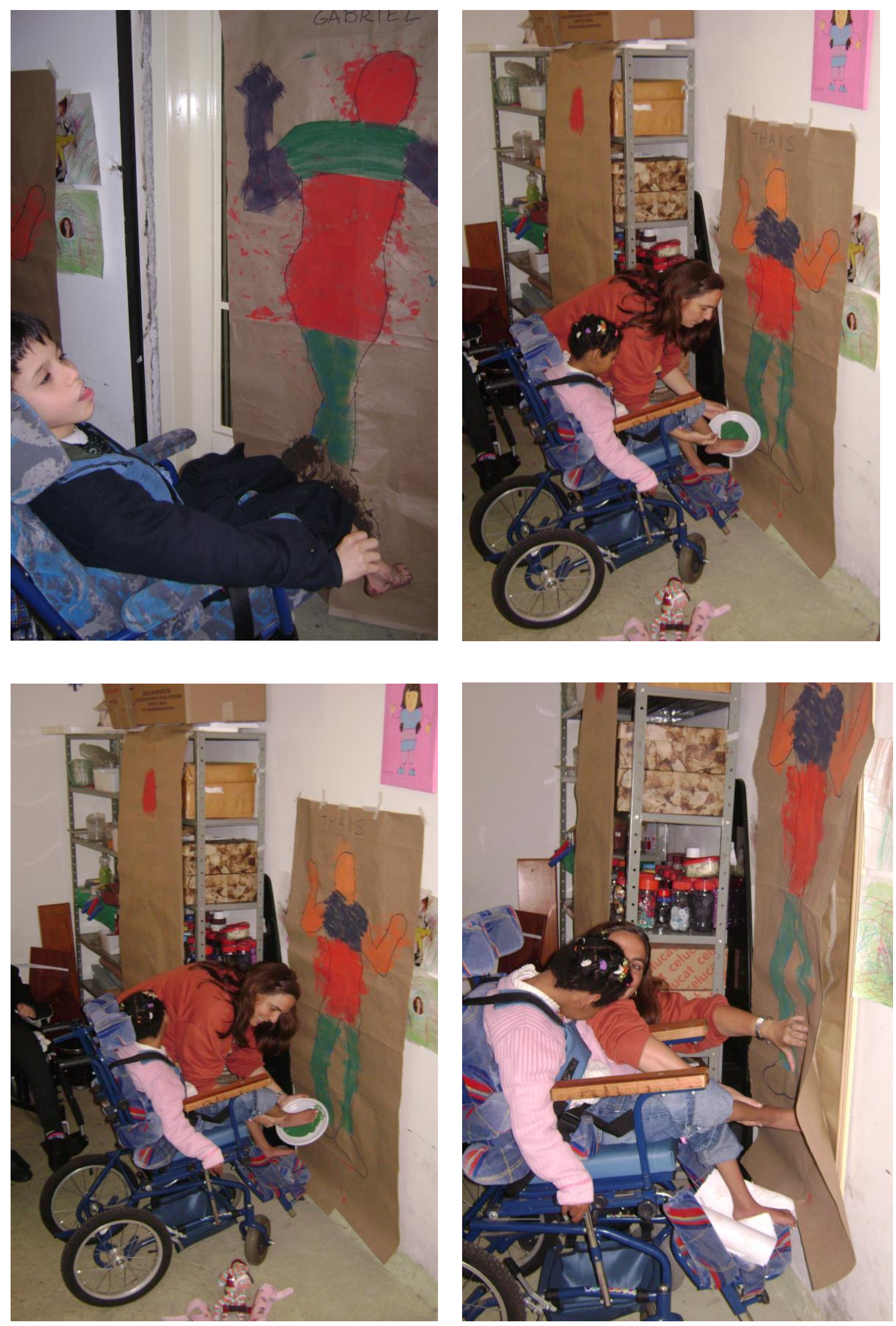

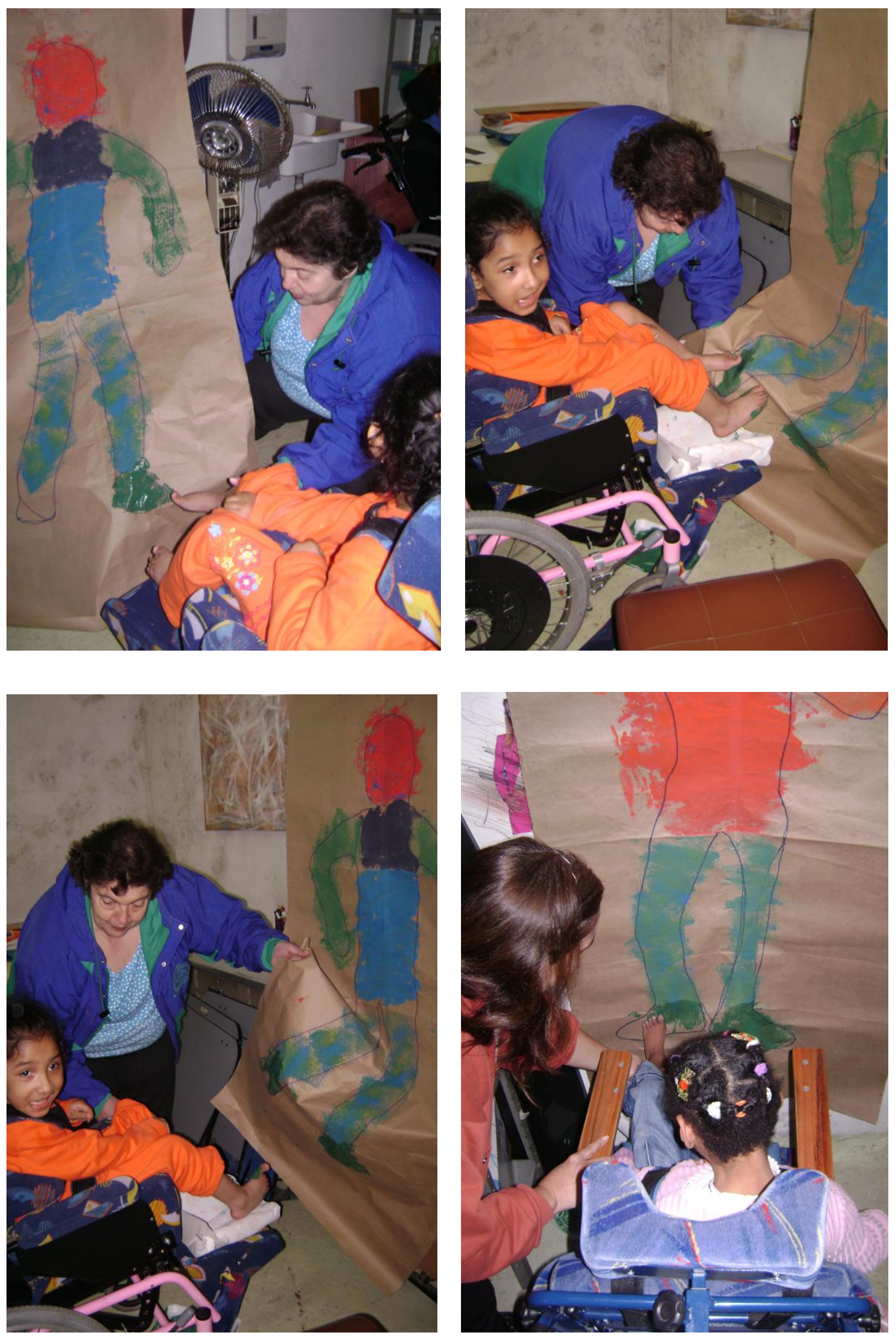


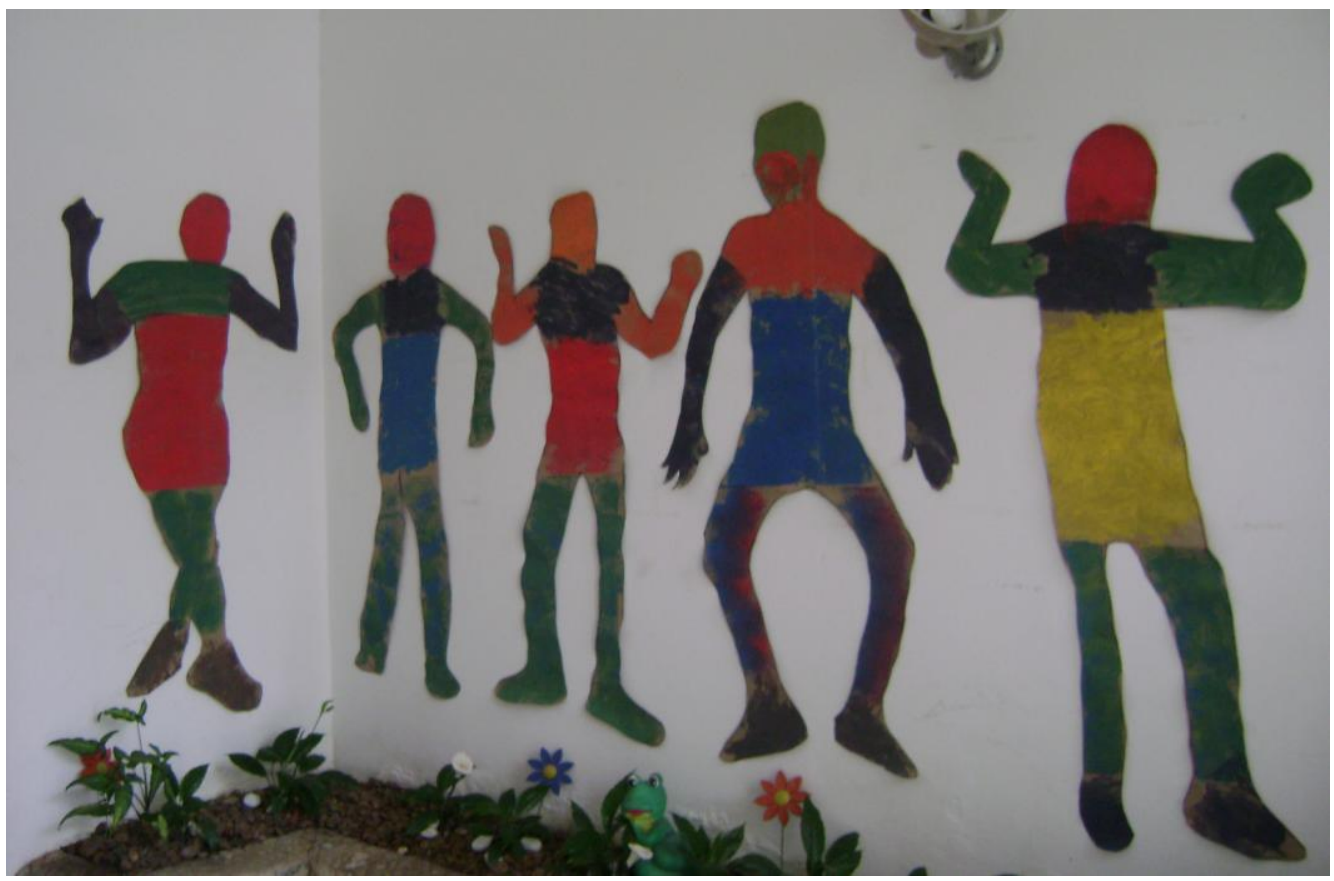

08/09/2008

NO DIA 26/08 FOI FANTÁSTICO! TO COMEÇANDO A ME SENTIR MAIS CONFIANTE E AI PLANEJO MELHOR. EU PENSEI A ATIVIDADE, E EM COMO POSSIBILITA-LA, COMO SE FOSSE PRA MIM. FIZEMOS O CONTORNO DOS NOSSOS CORPOS, EU COMECEI PARA QUE AS CRIANÇAS NÃO ESTRANHASSEM SEREM TIRADAS DA CADEIRA E DEITADAS SOBRE O PAPEL NO CHÃO PARA QUE A CECÍLIA PUDESSE TRAÇAR O CONTORNO DOS CORPOS. TODOS SE PORTARAM MUITO BEM.

NA AULA SEGUINTE 02/09 COMEÇAMOS A PINTAR O COR$P O$. (http://amaliabarbosa.zip.net)

A segunda atividade foi fazer um porta-retratos, pintá-lo com os dedos, bater a foto e colocá-la no porta-retratos. 

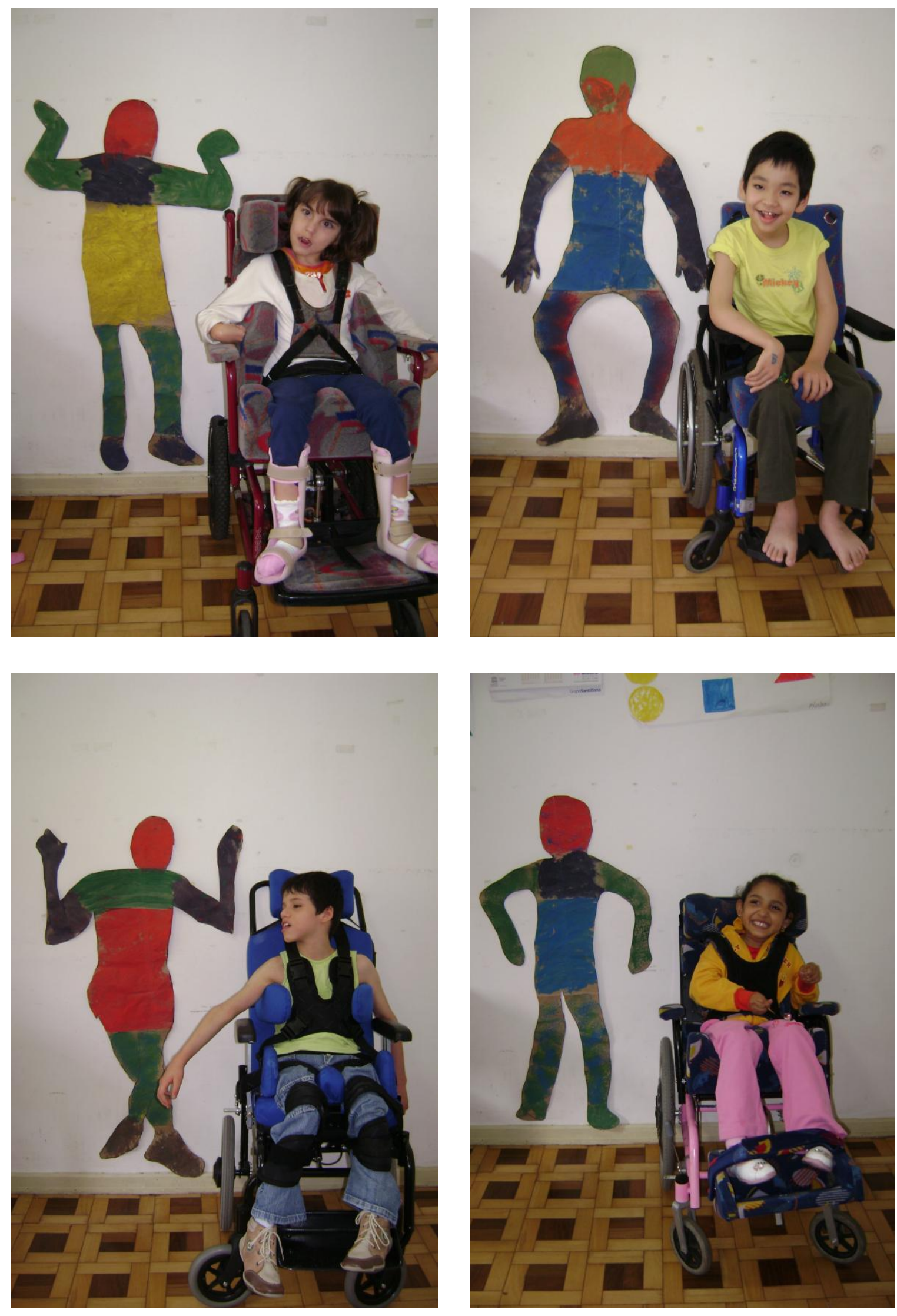

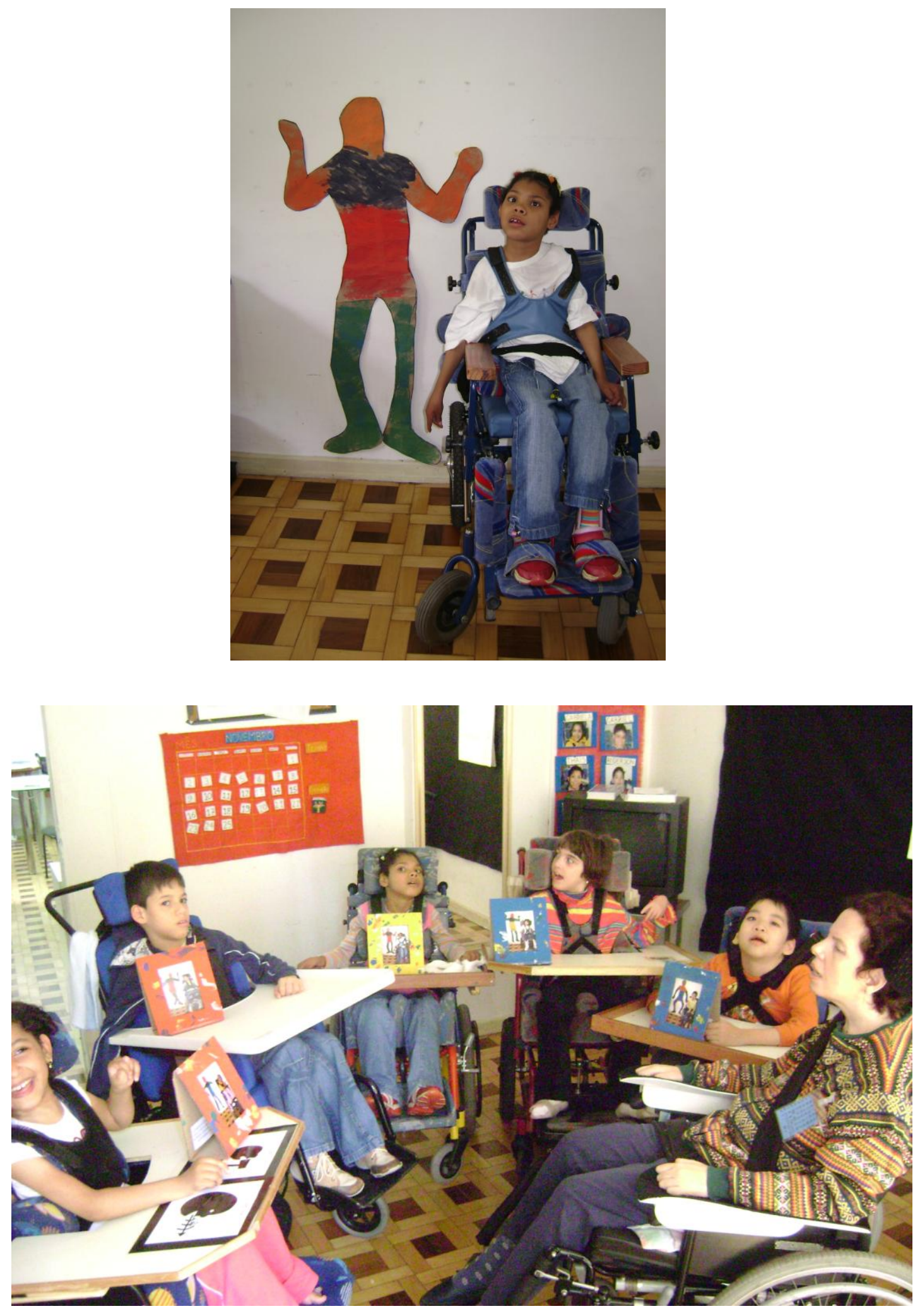

Em seguida, convidamos Adonay Donley um ator para pintar o corpo das crianças iniciando a trajetória do corpo como suporte. 
Adonay Donley é dramaturgo, cenógrafo e ator. Ele participou por mais de três anos do grupo que formei em 2001, Arteducação Produções para prestar serviços de Mediação Cultural em Museus, Centros Culturais, Casas de Cultura e exposições.

Afastei-me em 2002 por causa do AVC e voltei em 2004, quando ainda prestávamos serviços para o Centro Cultural do Banco do Brasil em São Paulo. Numa atitude ousada de colaboração para minha reinclusão no grupo, as gestoras do CCBB-SP comandadas por Suely Yamauti me convidaram para representar o educativo em um grupo que criaram de Educativos de instituições culturais de São Paulo que continua ativo até hoje. A criação deste grupo deve ter estimulado a criação de uma Rede Nacional de Educadores muito ativa.

O grupo de São Paulo é composto por instituições, a rede por educadores independentes de suas instituições. Não represento mais o CCBB-SP no grupo de São Paulo, mas continuo participando dele e organizei com Karen Kipnis, na Casa das Rosas um Seminário sobre Educação em Museus em outubro de 2010.

Grande suporte para meu trabalho e minha vida tem vindo dos amigos do Arteducação Produções como Moacyr Simplício, Edna Onodera, José Minerini Neto e Adonay Donlay que tem sido mais requisitados por mim. O grupo Arteducação Produções continua ativo, presta serviços para instituições da Prefeitura de São Paulo, foi muito ampliado por jovens pesquisadores e educadores e tem um blog que pode ser consultado por quem estiver lendo este texto.

http://arteducaoonline.blogspot.com/2011/12/site-do-aep-atualizado.html

As crianças adoraram ter seus corpos pintados, ornamentados, fotografados e comentados com deleite por todos os presentes.

Adonay no texto abaixo comenta suas experiências com meus alunos:

\section{UM GRANDE APRENDIZADO}

Ana Amália me convidou para trabalhar com pintura facial em seus alunos. Seria a primeira vez que eu faria tal oficina. Já havia tido contato com pessoas portadoras de necessidades especiais, crianças e adultos, no CCBB, como arte-educador e lá fui eu, conhecer a molecada. Levei minhas maquiagens, aquelas que saem com água e mãos à obra. Eu brincava com cada criança, sou meio palhaço, só para quebrar o gelo dessa minha invasão. Conhecia cada uma na- 
quele momento. Maquiei-as todas, me recordo que eram umas seis ou sete crianças, chamava-as pelo nome, e ia maquiando, passando o pincel em cada rosto, em cada braço, em cada mão e conversava com cada um, para depois mostrar em um espelho o que eu havia desenhado. Elas sorriam e eu me sentia realizado. Até a última criança, eu banquei o durão comigo mesmo, mas quando acabou e fui conversar com as professoras da turminha, pedi licença para ir ao toalete e lá, sozinho, sem ninguém para ver, descarreguei todas as lagrimas que pude chorar. Valeu como uma grande experiência.

Na segunda vez que Aninha me chamou, pediu que eu interferisse com eles, em uma máscara. Catei minhas bugigangas e tranqueiras, folhas de arvores, pedaços de plásticos, duros e moles, tampas de refrigerantes e sucos, fios, sisal, barbantes, lantejoulas, miçangas, tinha de tudo na minha mochila, e lá fui eu, desta vez, mais confiante. Lá chegando, reconheci alguns alunos e fiquei contente em poder estar ali com eles novamente. Desta vez, foi mais fácil a minha interferência, colocava papel, folha de arvore ou plástico em cada rostinho, desenhava, colava, cortava e montava uma mascara às vezes pequena, outras vezes grande e para botar medo (de mentirinha), eu fazia micagem e palhaçadas. Tocava em suas bocas, orelhas, mãos, braços, cabelos e com isso fui ganhando a confianças de cada um, o que mais tarde a Aninha veio me confirmar, o que me deixou bastante contente, que é muito difícil que eles se deixem tocar seus corpos e eu havia conseguido isso. Os sorrisos foram a moeda de troca. Acabada a oficina de mascaras, um toque em cada rosto, saí de lá muito feliz e desta vez, sem lagrimas e mais confiante em mim e muito mais no processo que essas crianças estão vivenciando, Parabéns, Ana Amália, parabéns professores e educadores dessa escola encantadora, parabéns a todos.Obrigado.
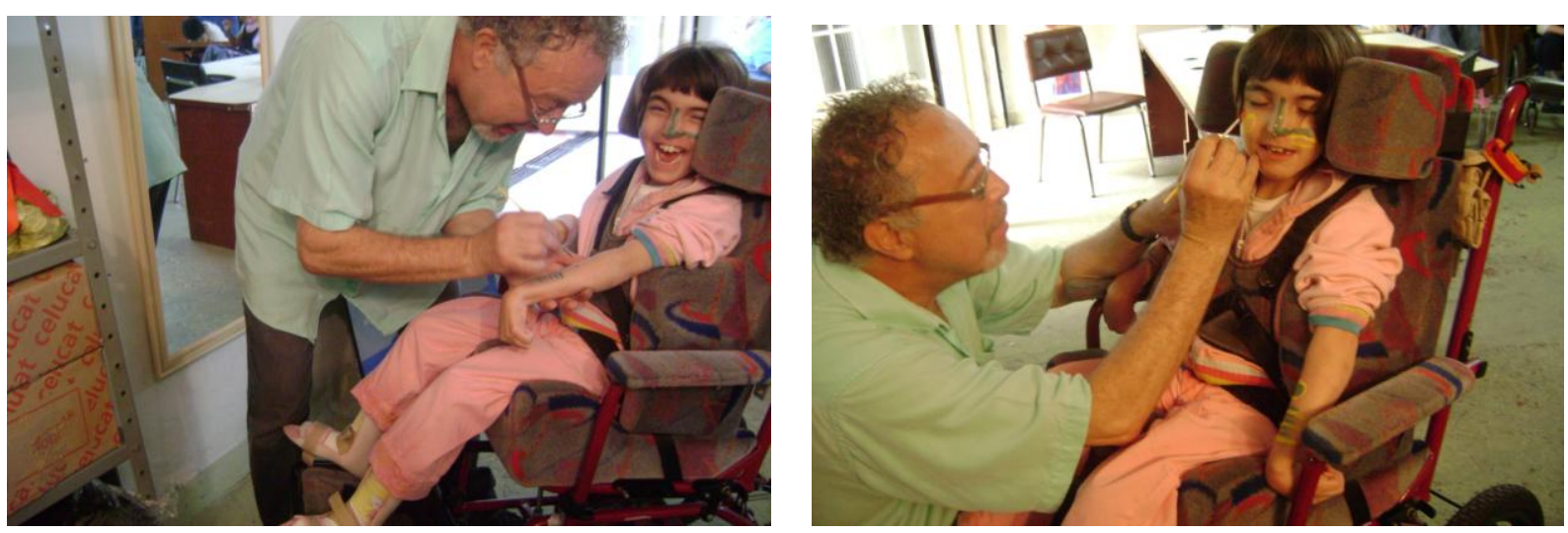

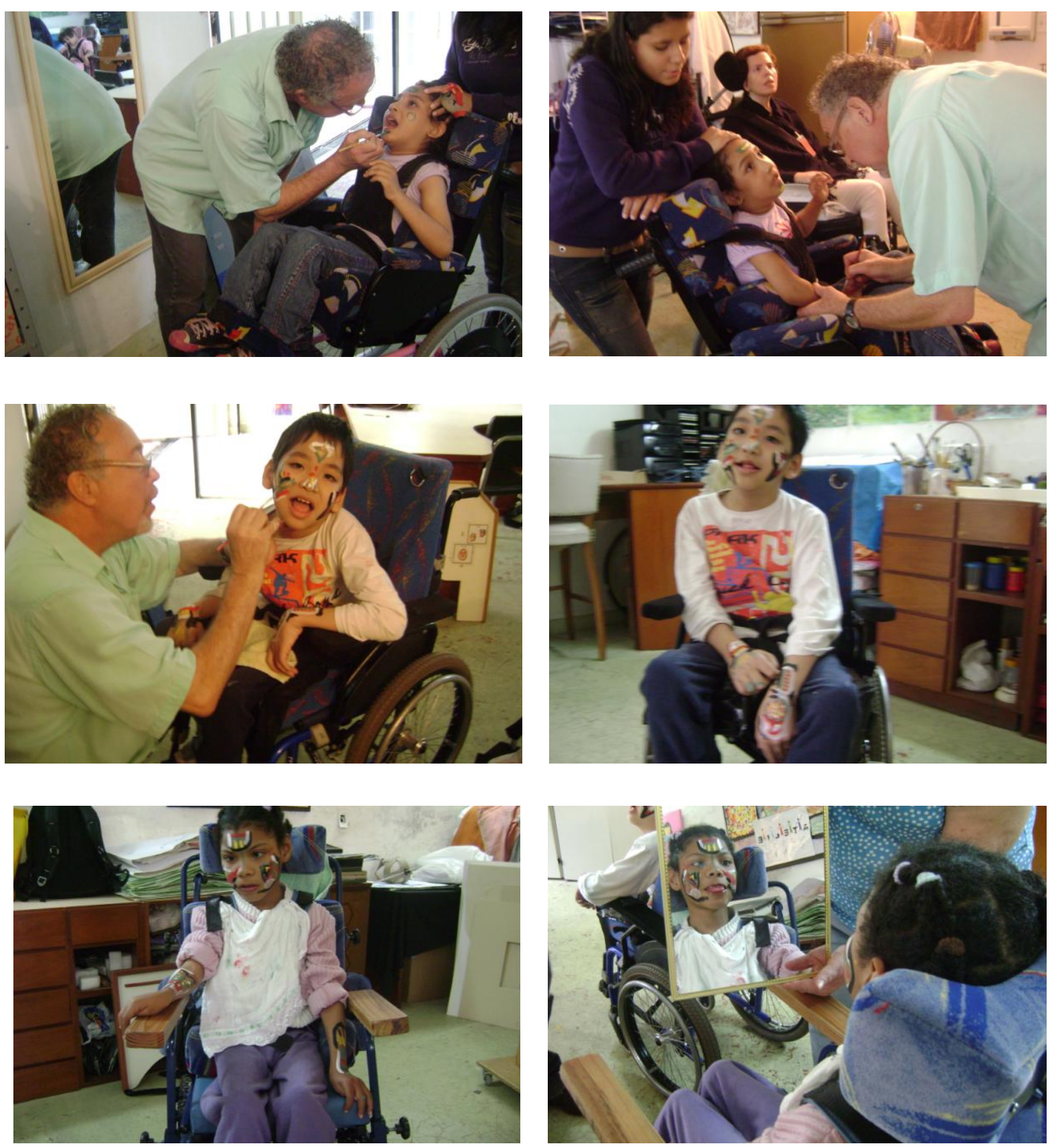

Esta série de atividades na qual gradativamente fomos trabalhando com a percepção das cores e do corpo, o sistema exteroceptivo e o sistema proprioceptivo, culminou com um trabalho baseado nas performances monocromáticas de Yves Klein tendo o corpo de bailarinas como incorporação dialógica da pintura. Ele pintava o corpo das bailarinas de uma só cor e as levava a dançar deitadas sobre a tela. É interessante observar que a cosmética teve um grande desenvolvimento no inicio da época moderna. Yves Klein a questiona ampliando a cor para todo o corpo mas diferentemente da cosmética moderna e da tatuagem milenar envolve o corpo de uma cor só, 
o azul que ele pesquisou juntamente com especialistas em Química durante muito tempo com diversos pigmentos chegando a cor que passou a se chamar "International Klein Blue" Havíamos estudado cores suas combinações gerando outras cores e com o vídeo de Yves Klein que mostrei a eles, no qual prestaram muita atenção o que procurei ressaltar foi o monocromatismo fazendoos descobrir que arte se pode construir sem cores ou com uma única cor. Ives Klein considera a pintura monocromática como "uma janela aberta para liberdade e a possibilidade de estar imerso na imensurável existência da cor" ${ }^{\text {"1 }}$ Este dialogo entre o multicolorido do expressionismo abstrato e o monocromatismo de Yves Klein intensificou a experiência da cor. O movimento dos corpos das bailarinas estimulou as crianças a experimentarem com muita intensidade a proposta que se seguiu depois de assistirem ao filme da performance de Yves Klein,no Youtube.

http://www.youtube.com/watch?v=x0mYZbYdIpU.

Propus que ficassem de fraldas ou de short e pintassem os seus próprios corpos com a cor que escolhessem. Depois usando o corpo como um pincel imprimissem movimentos numa grande superfície de papel. Foi uma das aulas mais divertidas e proporcionou uma movimentação muito ampla dos corpos. As professoras e os cuidadores que estavam presentes ajudaram as crianças a pintarem partes do corpo de difícil acesso para eles, como por exemplo, as costas.

O ideal teria sido levar uns a ajudar a pintar os outros, mas considerei que era importante não exigir demasiado de cada um e deixá-los mais seguros com a ajuda de adultos. A colaboração entre eles tem que ser cuidadosa e gradativamente planejada.
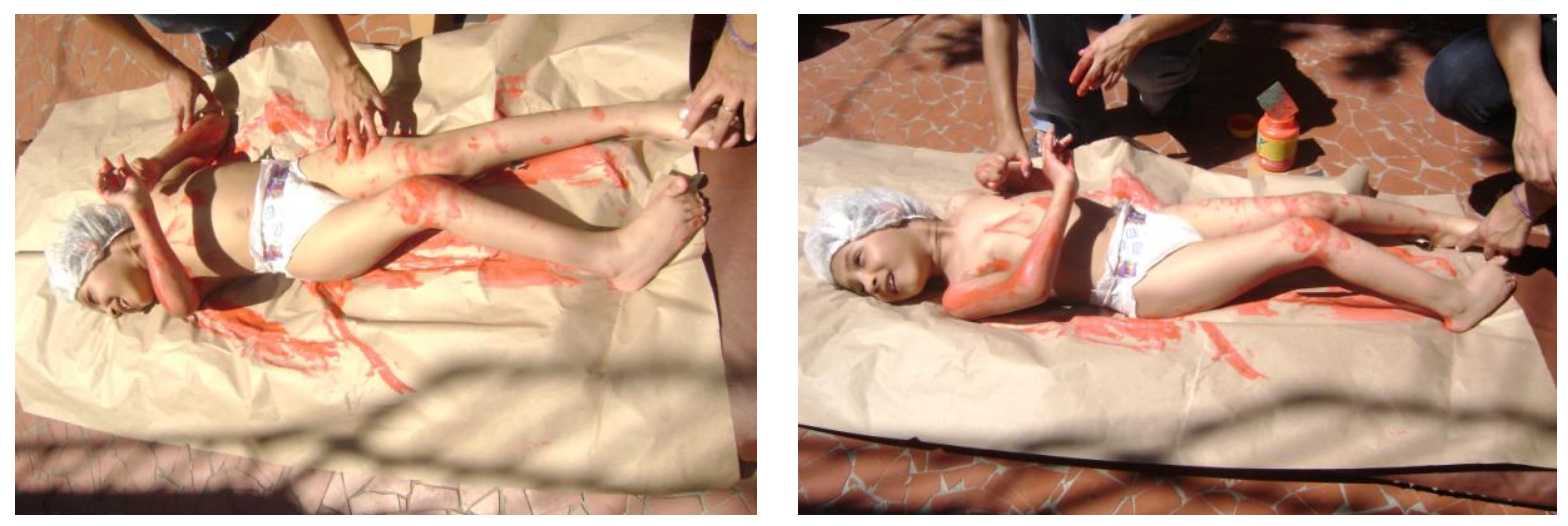

\footnotetext{
${ }^{1}$ Klein considered monochrome painting to be an "open window to freedom, and the possibility of being immersed in the immeasurable existence of color." http://www.dailyartfixx.com/tag/yves-klein/consultado no dia 19/12/2011 as 15:20
} 

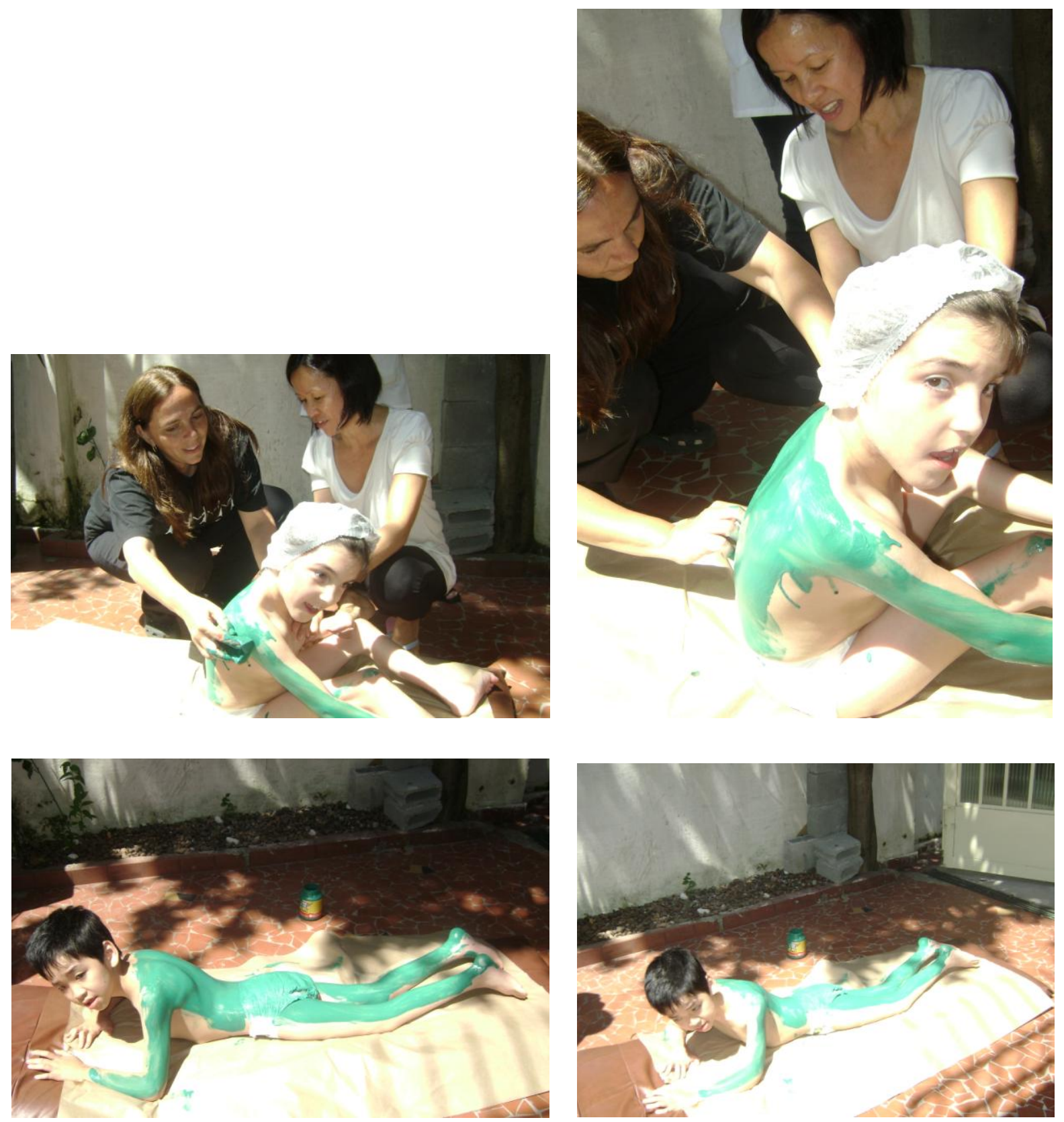

Apesar do pouco contato que tenho com eles, pude perceber uma maior consciência corporal e uma inventividade para ultrapassar os limites do próprio corpo.

Observei isto no caso de uma menina que vivia colocando o polegar na boca e, para que ela não se ferisse, enrolaram a mão dela, mas ela arrancou o pano com os dentes. Era a única maneira dela se desvincilhar de algo incômodo no corpo ao qual estava acostumada.

No primeiro semestre de 2009 o enfoque foi nas formas e no corpo em sociedade. Começamos pelo desenho de observação com lápis de cera, as crianças escolheram as formas. 

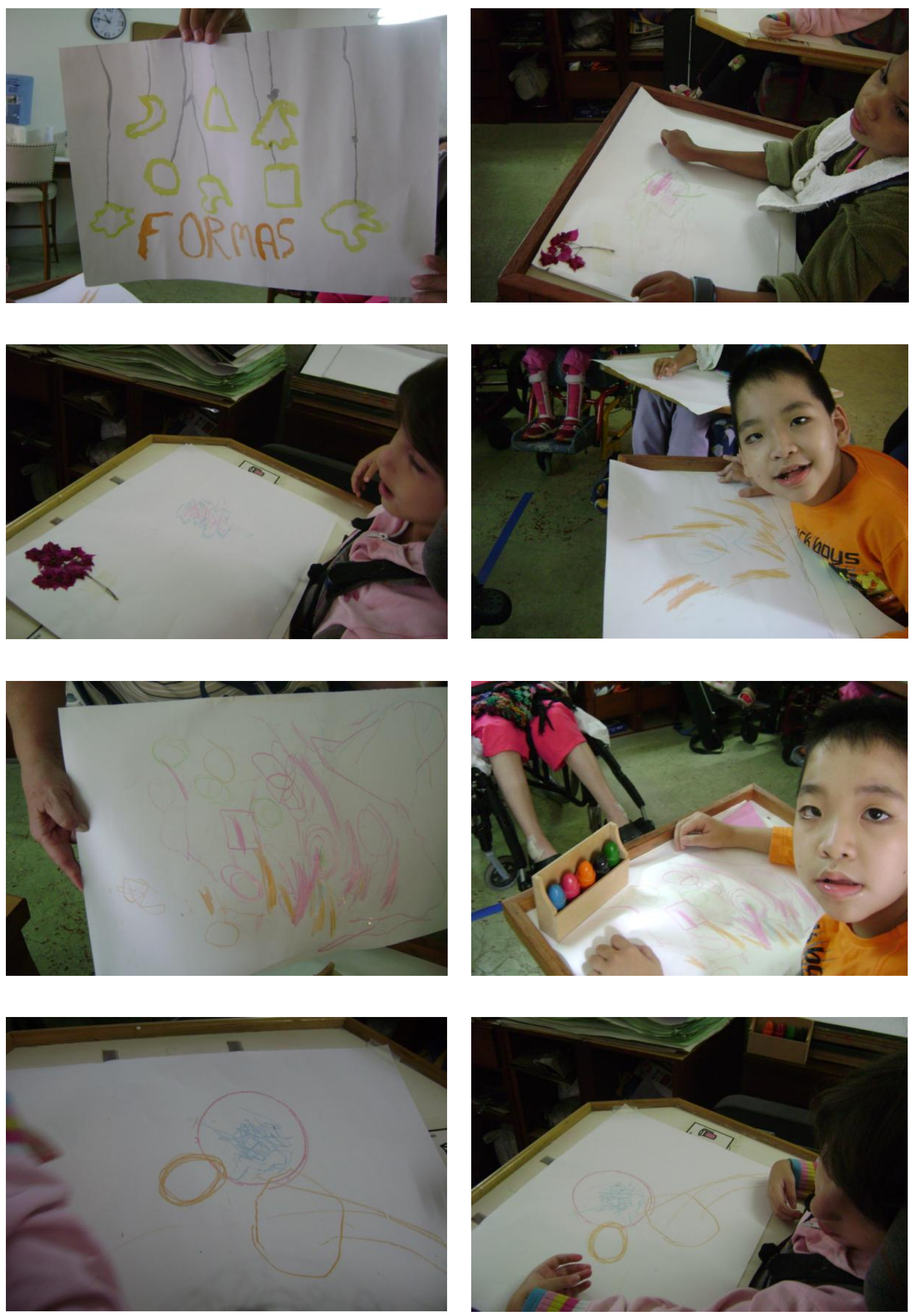

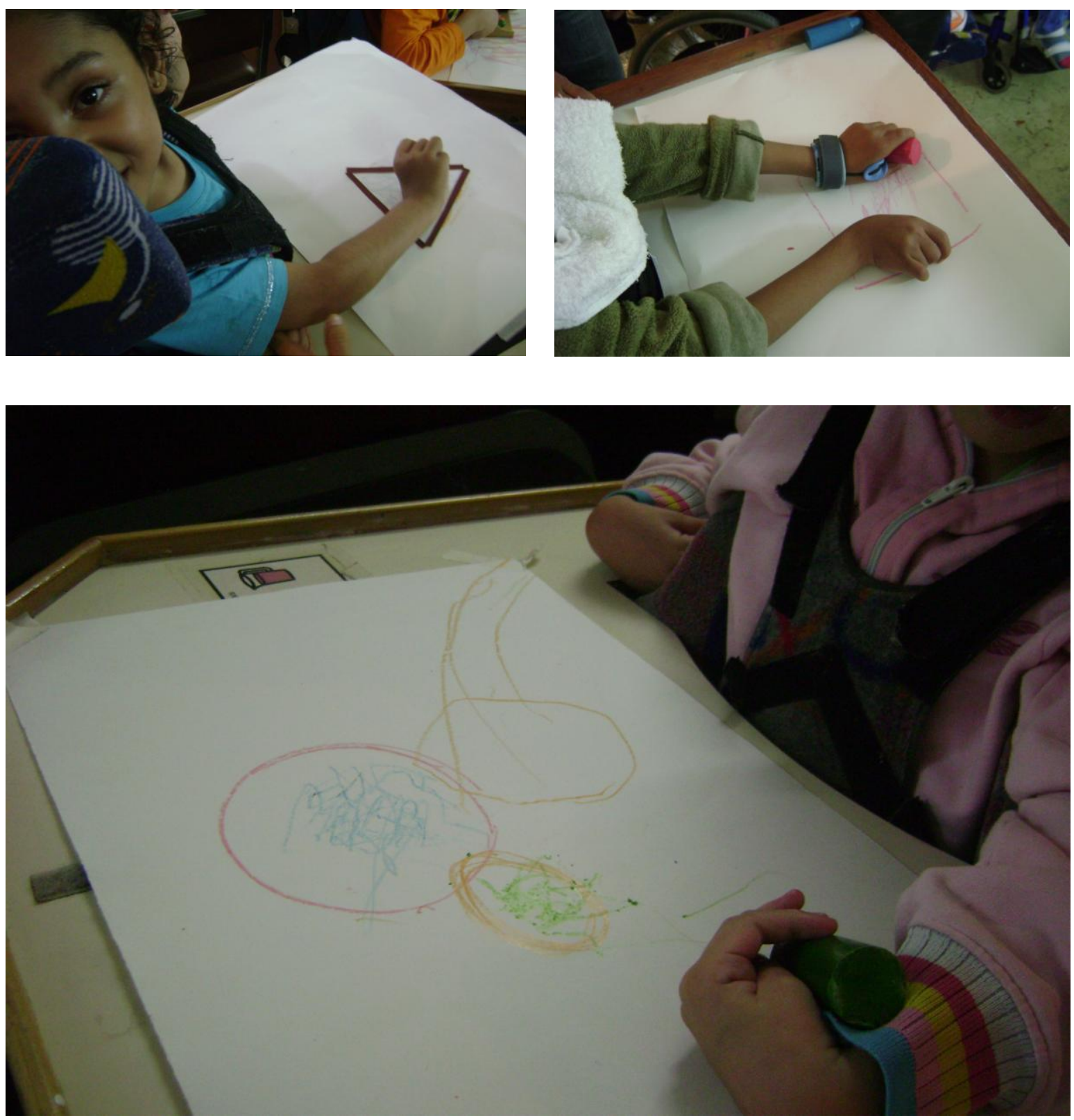

Depois estudamos Alexander Calder pelo enorme potencial perceptivo acerca das formas. Além da percepção do próprio corpo no espaço acrescentávamos a percepção do objeto externo no espaço. E assim criamos nosso próprio móbile.

Queria levar as crianças para ver um móbile do Calder, o maior e mais significante que temos na cidade de São Paulo o qual está no Instituto dos Arquitetos que não tem elevador. Fui até lá e a recepção da instituição foi no mínimo indiferente. É um Calder inacessível para deficientes e pessoas de idade avançada. A inacessibilidade está instalada no órgão máximo de arquite- 
tura do Estado de São Paulo. São os arquitetos que planejam os edifícios, isto explica em parte o desrespeito desumano pelos deficientes em seus projetos. Em vez disso fomos ao Instituto Tomie Ohtake, pois sabia que as esculturas de Tomie Ohtake estavam expostas e também proporcionariam uma experiência de interação entre o movimento originário da obra e o movimento das cadeiras de rodas de meus alunos. Seria possível para eles sentirem o movimento no corpo para além de suas cadeiras. Buscava provocar o diálogo entre movimentos e estimular a percepção.

No Blog descrevi a visita ao Instituto dos Arquitetos:
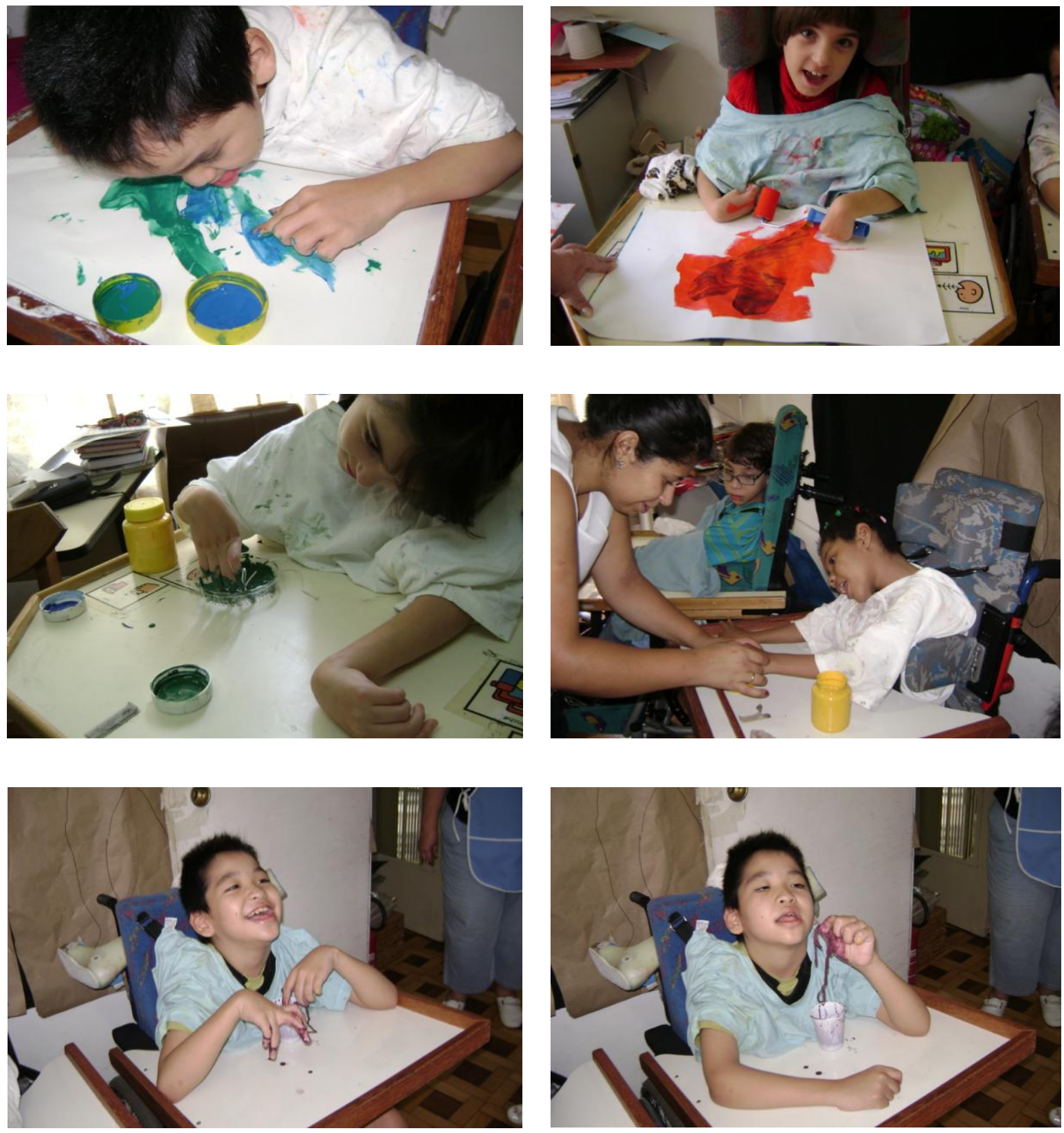

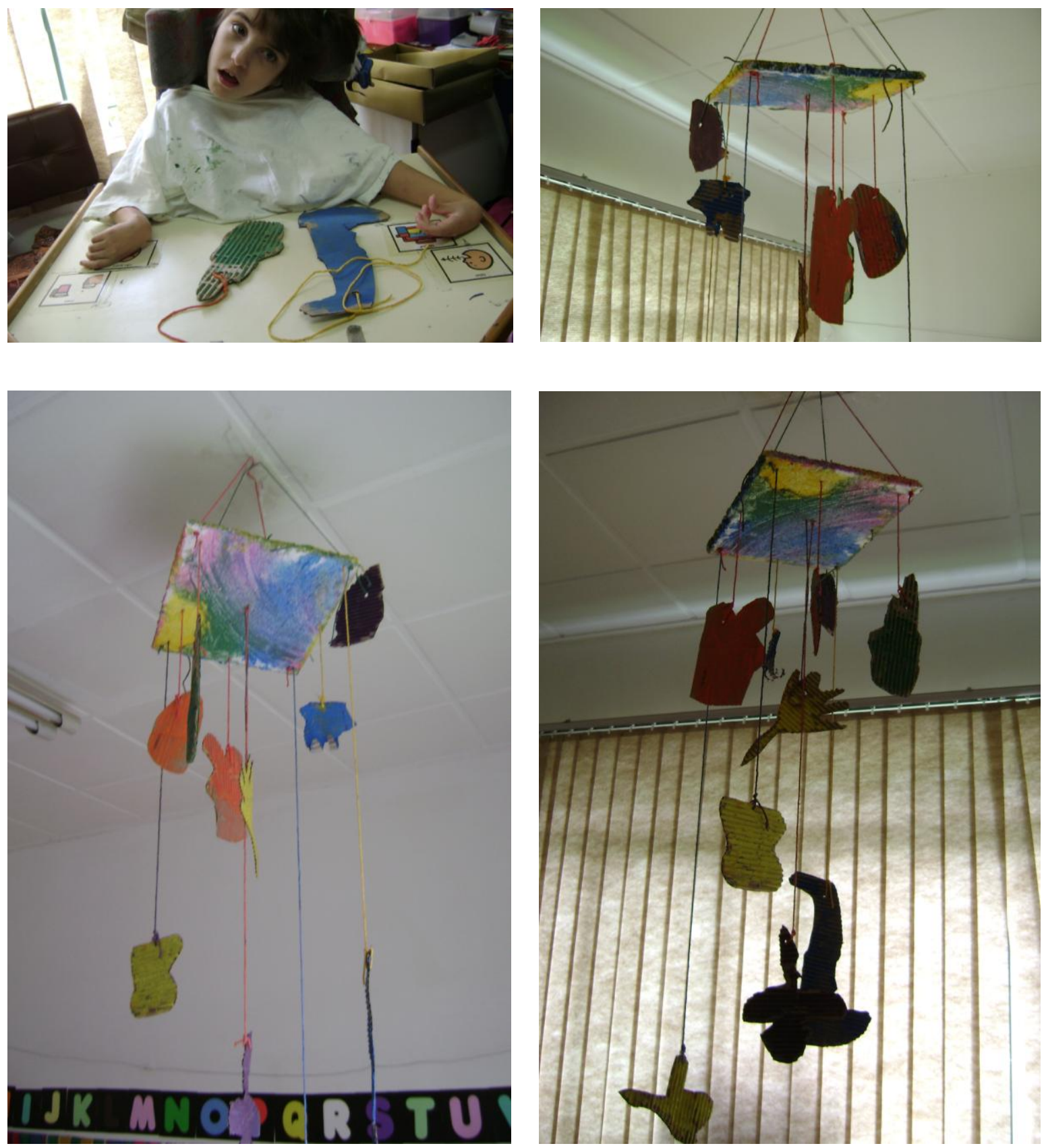

09/03/2009

SEMPRE USEI MEU MUIRAQUITÃ QUANDO IA ENFRENTAR UMA SITUAÇÃO DIFÍCIL, MAS QUINTA-FEIRA FIQUEI IMPRESSIONADA PQ ELE COMEÇOU A QUEIMAR A MINHA PELE 
DURANTE AQUELA SITUAÇÃO HORROROSA NO INSTITUTO DOS ARQUITETOS DO BRASIL. FOI O SEGUINTE:

-A PRESIDENTA DO INSTITUTO FOI DE MUITA MAH VONTADE, ALEGOU SEGURANÇA, MAS NA VERDADE A ATITUDE DELA ERA DE SE DESVINCILHAR DE UM PROBLEMA, QUE EH O ACESSO AO MOBILE DO CALDER POR CADEIRANTES. POR FIM, MESMO "BATENDO DE FRENTE" COM ELA UM FUNCIONARIO RESOLVEU SE ARRISCAR E COM AJUDA ME CARREGOU ESCADA ACIMA. (http://amaliabarbosa.zip.net)

Já a visita ao Tomie Ohtake foi muito facilitada pela instituição desde minha ida para checar as possibilidades de acesso físico.

12/04/09

DIA 05 - INSTI. TOMIE OHTAKE. FUI CHECAR PRA LEVAR MEUS ALUNOS. EH PERFEITO! NINGUÊM DOMINA TÃO BEM A FORMA E A COR! EU CONTINUO ABSOLUTAMENTE APAIXONADA PELO TRABALHO DELA. PRA COMPLETAR, O TRATAMENTO QUANTO À ACESSIBILIDADE EH FANTASTICO! COMEÇOU A CHOVER E OS SEGURANÇAS RAPIDAMENTE ARRUMARAM OUTRA SAIDA PRA MIM, A GENTE TAH TÃO ACOSTUMADA A TER QUE "SE VIRAR" QUE NEM ACREDITAVA! NOTA 9, SOH FALTA O DESIGNER DA EXPOSIÇÃO RESOLVER A ALTURA DOS QUADROS E O REFLEXO NO VIDRO. (http://amaliabarbosa.zip.net) 
Fizemos a visita e até a ida inesperada de uma equipe de TV foi facilitada pelos gestores da instituição. Minerini vai relatar esse episódio mais adiante em sua narrativa. Escrevi naquele dia no blog:

28/04/2009

EU TÔ "SOH O POH", MAS FOI ABSOLUTAMENTE FABULOSO!! HOJE LEVEI AS CRIANÇAS AO INSTITUTO TOMIE OHTAKE. FORA O FATO DE QUE VER AQUELAS CRIANÇAS FELIZES, ME DEIXE HIPER-FELIZ, FIQUEI MAIS QUE FELIZ AO PERCEBER $Q U E$

-FORMA E COR JAH SÃO CONCEITOS INTERIORIZADOS. COMO DISSE O NETO "ARMEI O MAIOR CIRCO" (vide dvd anexo). DESSA VEZ ATEH EU FIQUEI COM UM MEDO! (http://Amáliabarbosa.zip.net)

José Minerini Neto conta nossa história melhor do que eu, a minha mudez já por dez anos me tornou excessivamente sintética:

"Essa história começou em 2000. Recebi no colégio em que sou professor desde 1989 informações sobre um curso voltado a arte-educadores. Tratava-se de extensão universitária oferecido pelo Núcleo de Apoio à Cultura e Extensão da Arte na Educação - NASCE/NUPAE da ECA/USP.

Fui aluno desse núcleo durante 2 anos e concluí 4 cursos semestrais. Das turmas que lá participei, três alunos foram convidados pela professora Ana Amália para integrar a equipe que viria a participar da fundação do coletivo Arteducação Produções, cujo primeiro trabalho seria a implantação do Programa Educativo no Centro Cultural Banco do Brasil São Paulo (CCBB/SP), a ser inaugurado em abril de 2001. Eu e minha colega de turma Helda (não me lembro seu nome completo) fomos convidados a apresentar propostas de oficina. Outro colega, Márcio Molfi, foi investigado para representar legalmente o coletivo que então nascia. 
Por motivos diversos, dentre os três convidados, o único disponível para tal envolvimento naquele momento era eu. Topei, apresentei uma proposta de oficina com massa de modelar para o evento inaugural do CCBB/SP denominado "Metro: A metrópole em você" que de imediato não foi realizada (essa só foi realizada em 2003 na exposição Pop Brasil - última orientação oral que recebi de Ana Amália antes dela passar a viver sob síndrome de locked in) e atuei como propositor e orientador de oficinas no CCBB/SP durante 2001. Conciliar minhas atividades diárias em sala de aula aos compromissos de artista/educador e produtor cultural que realizava à época com as oficinas do $\mathrm{CCBB} / \mathrm{SP}$ gerou uma sobrecarga de trabalho enorme, motivo pelo qual deixei de conduzir as oficinas e passei a ocupar outras funções no Arteducação Produções. Dentre elas a de pesquisador e condutor de encontros voltados a educadores no mesmo $\mathrm{CCBB} / \mathrm{SP}$, atividades que me permitiam maior flexibilidade de horário.

Assim foi até julho de 2002 quando Ana Amália sofreu um acidente vascular cerebral (AVC de tronco) que a deixou tetraplégica e sem comunicação oral, chamada síndrome de locked in.

Graças a esse convívio com Ana Amália, minha atuação no Arteducação Produções e os trabalhos no CCBB/SP, conscientizei-me da necessidade de aprofundar meus conhecimentos em educação e em arte, o que me levou ao mestrado. Ingressei em 2004 no Programa de Pós Graduação Interunidades em Estética e História da Arte da USP e em 2010 no doutoramento da ECA/USP. No decorrer dessa trajetória, Ana Amália estabilizou sua saúde e estabeleceu seu novo modo de vida com síndrome de locked in, continuou a ser a mentora do Arteducação Produções e todos que com ela convivem não tiveram opções senão adequarem-se ao seu novo modo de vida. Entendo que isso levou-a a transformar completamente sua produção como artista e como artista/educadora, daí ela vir a integrar a equipe de educadores da Associação Nosso Sonho.

Eu sabia até então que Ana Amália havia se envolvido em uma pesquisa sobre ensino/aprendizagem da arte com crianças portadoras de paralisia cerebral na Associação Nosso Sonho e nada mais. Isso até ser convidado por ela no final de 2008 para mediar uma visita com as crianças da Associação Nosso Sonho em alguma exposição que se relacionasse ao artista Alexander Calder. De imediato, pensei no móbile "Viúva Negra" que conheci em exposição dedicada ao artista na Pinacoteca do Estado e que pertence ao Instituto dos Arquitetos do Brasil (IAB) em São Paulo. Essa visita foi idealizada por mim e Ana Amália e se confirmou inviável pelas condições de acessibilidade no prédio do IAB, pois o móbile fica no $4^{\circ}$ andar de um edifício que não possui 
elevador até lá. Daí a impossibilidade: como levar crianças com paralisia cerebral que necessitam de cadeira de rodas para um prédio sem acessibilidade?

Fiz com Ana Amália um levantamento sobre quais exposições poderiam atender ao seu projeto de aula e ela indicou exposição de gravuras de Tomie Ohtake no Instituto dedicado à artista. Por e-mail ela me orientou sobre o trabalho com formas abstratas que estava realizando com as crianças e sugeri uma visita calcada na busca e identificação de formas abstratas nos trabalhos de Tomie expostos.

Visitei a exposição antes, selecionei algumas formas e cores que integravam as gravuras, providenciei folhas de papel colorset e recortei nelas formas encontradas nas gravuras porém com as cores alteradas. Daí a proposta: cada uma das crianças tinha que encontrar uma cor e uma forma na exposição.

No dia da visita - 28 de abril de 2009 - acordei cedo mas tinha que recortar as formas no colorset antes de sair de casa, o que atrasou minha chegada no local combinado. Ao chegar no Instituto Tomie Ohtake encontrei Ana Amália e as crianças prontas em suas cadeiras de rodas e uma equipe da TV Record pronta para nos acompanhar e registrar tudo. Com a presença da TV o desafio foi muito maior: como conduzir pela primeira vez uma visita para crianças com paralisia cerebral sendo registrado por um programa de televisão que até então eu não sabia que estaria lá? Também não sabiam da presença da televisão os funcionários do Instituto que vieram de imediato abordar a mim e aos acompanhantes/responsáveis da Associação Nosso Sonho. Optei por realizar a visita que havíamos planejado e só no final tive tempo para conceder entrevista para Record.

Após as crianças e Ana Amália serem acomodadas nos carros e partirem é que caí em mim. Ri e chorei enquanto caminhava sem certeza de onde ir quando telefonei para outra integrante do Arteducação Produções (Edna Onodera) e relatei aos berros o que havia acontecido há pouco. Resultados: a edição da Record é "sentimentaloide" nos moldes dos reality shows vigentes, o vídeo foi parar no youtube http://www.youtube.com/watch?v=pOpTVikR2uA e aspectos heroicos infundados foram destacadas, o que não corresponde a tamanha dedicação e envolvimento.

Certamente sabendo que eu estava anestesiado e muito envolvido graças à minha experiência na exposição de Tomie, Ana Amália convidou-me a conduzir outra visita com as crianças da Associação Nosso Sonho na exposição "Arte Contemporânea para crianças” no SESC Pompeia. 
Tornei-me professor universitário assim que defendi minha dissertação de mestrado no início de agosto de 2007. Rejane Coutinho - também minha professora no NASCE/NUPAE e fundadora do Arteducação Produções junto a Ana Amália e Sofia Fan, recebeu informação de Monica Moura - diretora da Escola de Artes da Universidade Anhembi Morumbi - sobre a necessidade de professor de história da arte com conhecimento em arte contemporânea e indicoume para a função. Fui contratado e hoje coordeno o curso de Artes e Novas Mídias dessa instituição. Nessa nova função, venho oferecendo a cada final de semestre visitas a exposições aos meus alunos de bacharelado e licenciatura em Artes e Novas Mídias. Sabendo da exposição no SESC Pompeia, agendei visita mediada e lá fui com meus alunos na intenção de analisar como os educadores conduziram a visita e também preparar minha atuação com as crianças da Associação Nosso Sonho.

A visita foi preparada novamente com a intenção de cada criança encontrar algo na exposição. Dessa vez não entreguei formas coloridas em colorset, apenas disse quais seriam as funções. Uma deveria encontrar movimento, outra deveria encontrar cor, outra um som e finalmente uma deveria encontrar a vassoura de uma bruxa. Transitei das questões formais às questões simbólicas calcadas na interação e nas proposições ambiental de Hélio Oiticica. Embora o artista na possuísse trabalhos presentes na exposição, seu legado era facilmente percebido em algumas obras expostas(vide texto anexo). Sem nada que me atrasasse, cheguei ao SESC depois de Ana Amália mas antes das crianças.

Começamos a visita com as crianças já familiarizadas comigo e eu com elas. Aos poucos os trabalhos foram visitados e as missões delegadas a cada criança foram se revelando. Tomei um susto enorme quando estávamos no trabalho de Eduardo Sued quando ao movimentar um dos muitos tecido da obra quase arranhei o rosto de uma das crianças. Havia discutido com Ana Amália e com a terapeuta ocupacional Marisa Hirata a possibilidade de retirar as crianças das cadeiras de rodas para interagirem com obra de Ernesto Neto em com os fios da vassoura de Cildo Meireles. Tudo combinado, porém, nenhuma das obras permitiu deitar as crianças pois estavam sujas. Estive na obra de Ernesto com meus alunos da Universidade e saí de lá com um cheiro horrível no corpo e sugerindo que a obra fosse interditada, tamanho o problema de higienização que acarretava. Os fios da obra de Cildo estavam muito empoeirados e também não foi possível colocar as crianças. Mas, o plano de retirar as crianças das cadeiras ainda estava em pé. O último trabalho visitado na exposição foi justamente o que continha a vassoura da bruxa que estávamos buscando 
e perguntamos às crianças quais delas gostariam de sair da cadeira e serem levadas até a vassoura nos braços. Havia acesso para as cadeiras mas mesmo assim oferecemos essa possibilidade e algumas aceitaram. Confesso que não me lembro quantas e quais pois a responsabilidade era tão grande que não me permitiu atentar ás particularidades. Algumas das educadoras da exposição que nos acompanhavam desde o início também pegaram crianças no colo assim como eu e as conduziram até a tão procurada vassoura. Voltamos as crianças para as cadeiras, conduzimos até a vassoura aquelas que não quiseram ser carregadas e a visita terminou.

As crianças foram acomodadas em carros e partiram. Eu, Ana Amália e sua enfermeira nos sentamos na cafeteria que fica em frente à exposição para avaliarmos juntos a visita e ali não me contive. Se na experiência da visita no Tomie Ohtake eu ri e chorei sozinho, ali fiz o mesmo na frente dela para em seguida me recompor no banheiro ao lado. Fica aqui uma pergunta: Por que rir e chorar depois dessas visitas? Medo, coragem, estética, experiência completa... Não sou capaz de responder. Recebemos naquela mesa de café Marcela Tibone, responsável pelo projeto educativo da exposição, conversamos e assim que o Táxi para cadeirantes de Ana Amália chegou ela partiu. Eu voltei à exposição para me despedir de uma aluna na Universidade que trabalhava na exposição. Enquanto a procurava, um dos seguranças do SESC parabenizou-me dizendo que também tem um familiar deficiente e que lida do mesmo modo como fiz na exposição: sem subestimar capacidades. Esse comentário me trouxe muita satisfação com o que eu havia proporcionado às crianças. Até agora não sei exatamente o que ficou em mim dessa visita!

Novo convite de Ana Amália trouxe novo desafio. Ela estava trabalhando tridimensionalidade com as crianças e me propôs visitar uma exposição de esculturas. Pensamos no Jardim das Esculturas do Parque da Luz mas nos defrontamos com o trânsito que poderíamos enfrentar ao levar as crianças de Perdizes até lá. Sugeri que fossemos de trem da Estação Barra Funda até a Luz. Nas visitas anteriores, Ana Amália visitou as exposições com seu marido e sua filha antes de levar as crianças para conhecer e avaliar obstáculos. Dessa vez, os obstáculos foram enormes. Primeiro ela foi até o trem da Barra Funda e sem orientação nenhuma não conseguiu transpor o vão que separa o trem da plataforma, o que não acontece no Metrô. Optou por ir de Metrô, embarcou, fez baldeação entre linhas e chegou até o jardim das esculturas. Trajeto longo, não foi por ela aprovado. Com o apoio de Edna Onodera e Adonay Donley, o Arteducação Produções contatou a CPTM, empresa responsável pelo sistema ferroviário de São Paulo. Essa empresa possui o programa educativo "Usuário do Amanhã" e prontamente se disponibilizou a fazer uma viagem 
com Ana Amália. Foi uma tarde na qual reinou uma mobilidade maravilhosa para mim e Ana Amália: a responsável pelo educativo da CPTM, o entusiasta e mentor de acessibilidade nos trens e dois policiais militares preparados para transportar deficientes físicos nos aguardavam no Terminal Barra Funda e nos conduziram durante todo o trajeto. Era segunda-feira, dia em que o Jardim da Luz está fechado para manutenção e portas, portões, escadas e rampas em nada dificultaram nossos acessos.

Durante esse passeio na "estrada de tijolos amarelos" recebemos orientações de como deficientes físicos podem usufruir plenamente do transporte público em São Paulo e recebemos materiais educativos desenvolvidos pela CPTM no final da viagem, na qual volta e meia ouvíamos que a equipe do programa "Usuário do Amanhã" estava momentaneamente desfalcada. Esse foi o mal sinal emitido que se confirmou nos dias seguintes: fomos informados que o programa estava momentaneamente suspenso e que a CPTM não poderia nos receber. Mas, como a visita estava agendada resolvemos arriscar. Era véspera da Virada Cultural 2010 e várias ruas do centro estavam interditadas para que a montagem de palcos pudesse acontecer. Eu cheguei atrasado, Ana Amália também e as crianças mais ainda. Restou-nos apenas 30 minutos para realizar a visita. O Táxi que transporta cadeirantes não cumpriu o agendamento com Ana Amália, ela foi em um Táxi comum com a cadeira desmontada no porta-malas. Um educador da Pinacoteca (ele nos disse que é habituado a montar cadeiras de rodas porque trabalha com um grupo de teatro de cadeirantes) percebeu que nem eu nem a enfermeira sabíamos montar a cadeira e nos socorreu. A Manhã estava fria, Ana Amália usava um sobretudo que dificultava movimentá-la mas mesmo assim foi acomodada na cadeira.

As crianças chegaram quando estávamos terminando de acomodar Ana Amália na cadeira e a visita começou com muito atraso. Quando lá estivemos apoiados pela CPTM, planejamos uma visita calma que exploraria questões referentes ao universo da escultura que iniciariam com as discussões cheio/vazio, dentro/fora e estático/movimento a partir dos trens. Ao sabermos que não iríamos de trem essas questões foram cortadas ou adaptadas para o Jardim das Esculturas, mas não contávamos com tão pouco tempo. É importante destacar que atrasos nessas visitas não são permitidos porque as crianças se deslocam até a Associação Nosso Sonho graças ao serviço do Atende. Cortamos a grande maioria do que havia sido planejado, porém, ainda de acordo com a aula planejada, iniciamos a visita discutindo dimensões em escultura de Liuba, volume (cheio/vazio) usando bexigas que foram depositadas junto à escultura de Lygia Reinach. Ana Amália 
concordou, desde que não estourássemos as bexigas perto das crianças para não assustá-las; uma estourou mas as crianças não demonstraram espanto. Fizemos essa atividade, passamos por escultura de Caíto e finalizamos uma comparação com escultura viva dos condutores/profissionais da Nosso Sonho para comparar figurativo e abstrato com obra de Carlito Carvalhosa. A visita na escultura de Caíto foi pontuada pelas ideias de escala, plano e espaço tridimensional (já levantada na primeira obra de Liuba). Conhecer a escultura de Caíto foi fundamental porque o artista esteve na semana seguinte dando uma aula para as crianças na sede da Nosso Sonho que infelizmente não pude presenciar.

A visita se encerrou com pouco mais de trinta minutos e as crianças voltaram para a Nosso Sonho. Eu, Ana Amália e sua enfermeira continuamos no Jardim documentando as esculturas. Dessa vez a sensação de cumprimento parcial das atividades aliada a grande frustração é o que ficou.

Já tive vários alunos deficientes em minhas classes regulares e até então não havia conduzido atividades com turmas exclusivas de deficientes. Atuar com esses alunos é desafio dos grandes, por vezes muito satisfatório, emotivo, noutras empolgante ou frustrante mas certamente desafiador. Que venham novos convites."

Queria levar as crianças para ver um móbile do Calder, mas era inacessível, em vez disso fomos ao Instituto Tomie Ohtake.

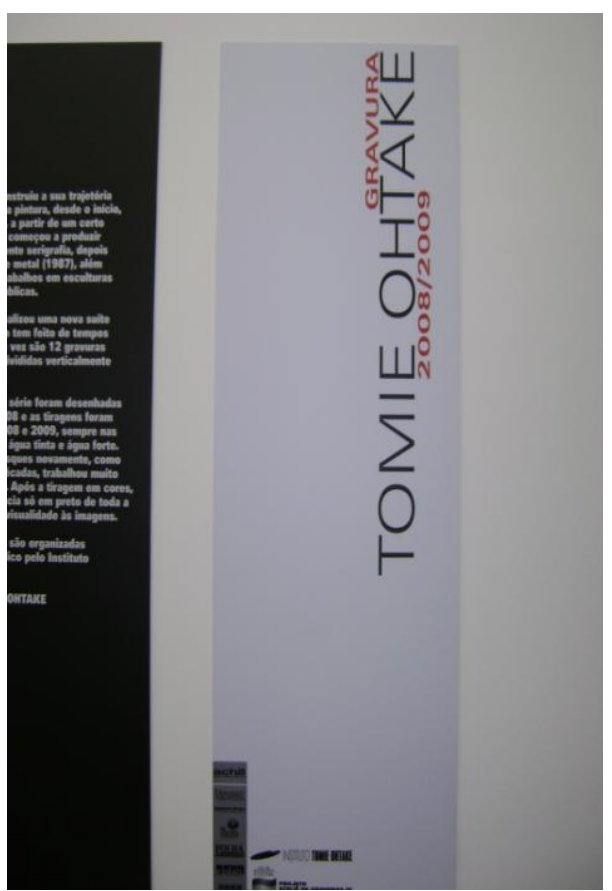



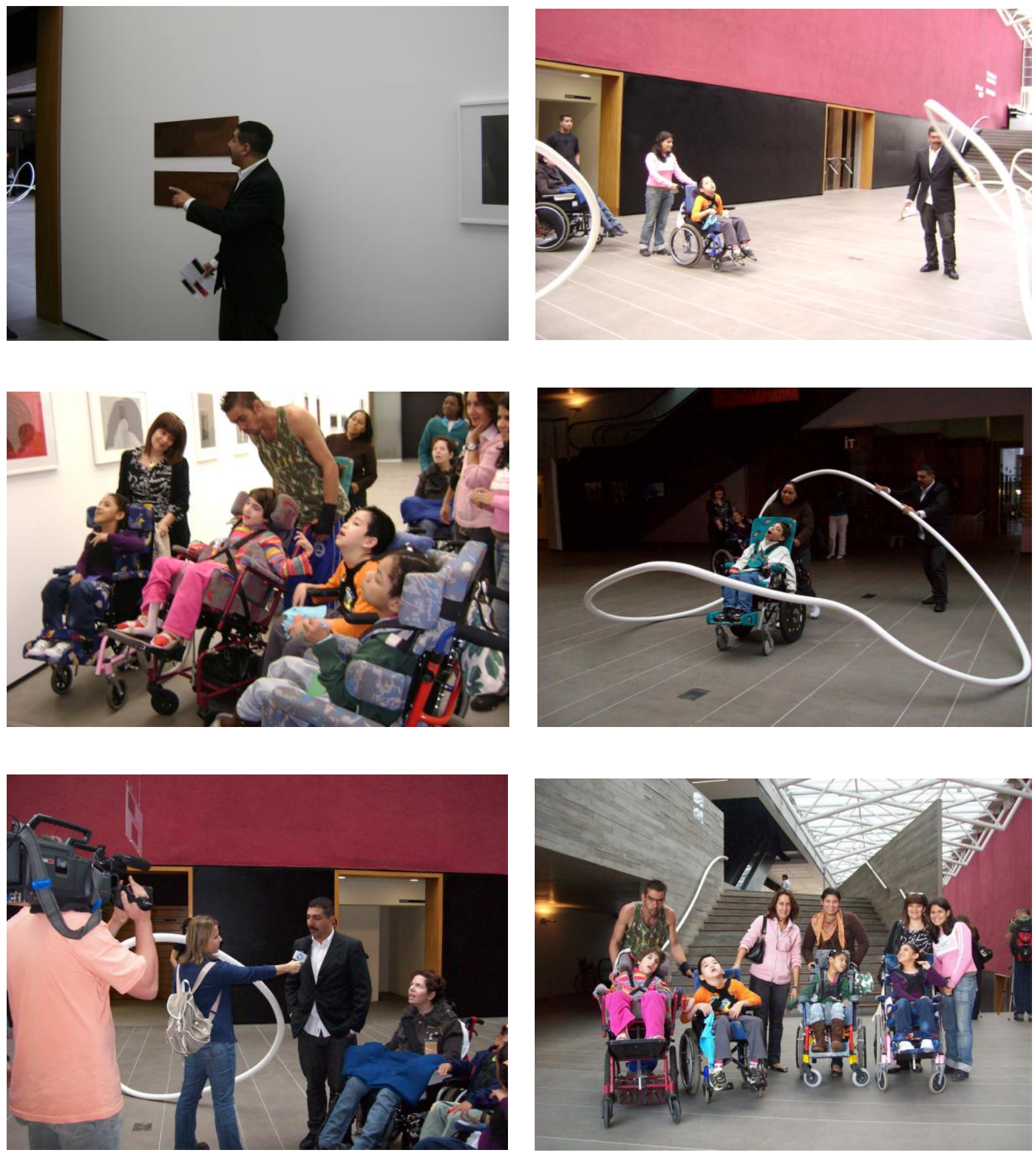

24/05/09

FOMOS VER A EXPOSIÇÃO ARTE PARA CRIANÇAS ${ }^{2}$ MUITO BOA! FUI MUITO BEM ATENDIDA PELA MONITORA; NO

\footnotetext{
${ }^{2}$ Exposição de arte contemporânea especialmente criada para crianças, que reúne artistas de diferentes gerações que trabalham linguagens diversas. Sob curadoria de Evandro Salles, foram selecionados trabalhos de Amilcar de Castro, Athos Bulcão, Cildo Meireles, Eder Santos, Eduardo Sued, Emmanuel Nassar, Ernesto Neto, Lawrence Weiner,
} 


\section{DIA 19 NETO FOI COMIGO AO "NOSSO SONHO" PARA CON- VERSARMOS COM OS ALUNOS SOBRE A EXPERIENCIA NO INSTITUTO TOMIE OHTAKE. (http://amaliabarbosa.zip.net)}
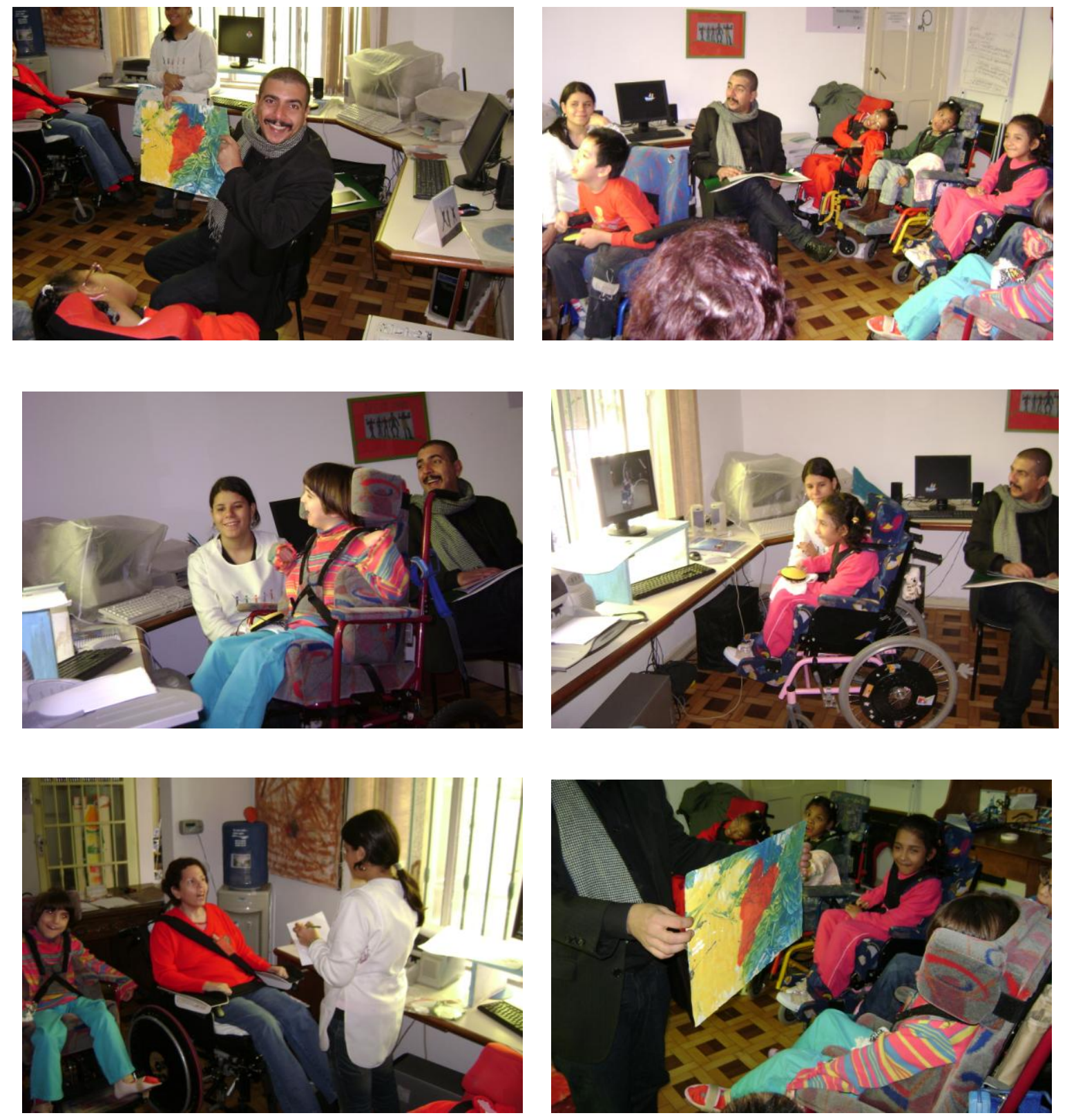

Mariana Manhães, Nuno Ramos, Rubem Grilo, Tunga, Yoko Ono e as vídeo-histórias "Histórias da Unha do Dedão do Pé do Fim do Mundo", com poemas de Manoel de Barros, roteiro de Bianca Ramoneda e música de Tim Rescala; "Sobre Dois Quadrados", uma fábula suprematista de El Lissitzky; e "Xipófagas Capilares Entre Nós", baseado na obra homônima de Tunga. 

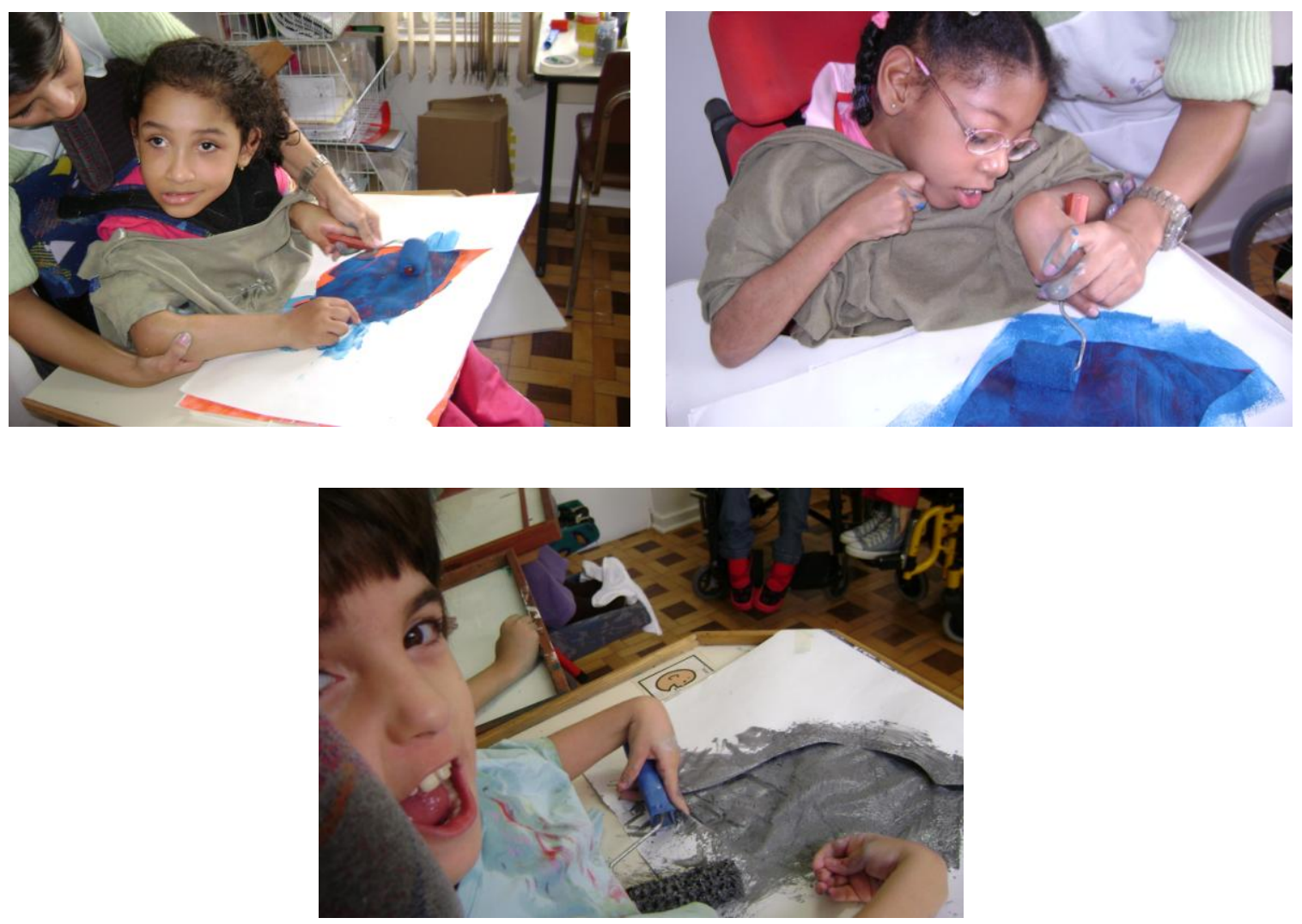

Pensando no corpo em sociedade levei-os a uma exposição de arte para crianças no SESC Pompeia.

Fomos acompanhados também pelo professor José Minerini Neto como ele já relatou. A exposição era interativa com várias instalações.

A instalação que mais entusiasmou os alunos foi a de Eduardo Sued, justamente uma reinterpretação conceitual e material do Magic Square de Hélio Oiticica que correspondia ao que Oiticica pensava de uma proposição associada a um conceito.

Para Oiticica, executar uma proposição associada a um conceito era colocar o conceito à prova, testá-lo e assim possibilitar que ele se transformasse e se concretizasse" (se estabelecesse) como conceito. Daí o uso da mesma palavra para designar um conceito e um projeto-programa, como Tropicália ou Parangolé. Os conceitos eram propostos em estruturas abertas o suficiente para serem aplicadas a vários indivíduos, sem terem sido feitas para nenhum deles especificamente, estratégia que Oiticica nomeia de propor propor: (BRAGA, 2011, p. 261)

A interatividade não era apenas designativa nesta exposição era realmente operativa, correspondendo novamente ao que Helio Oiticica propunha. 
É importante que a ideia de ambiente, participação, experimentos sensoriais, etc não sejam limitadas a soluções de objeto; elas devem propor um desenvolvimento de atos de vida e não uma representação a mais (a ideia de "arte"); novas formas de comunicação; a proposição para um novo comportamento descondicionado. (HÉLIO OITICICA apud BRAGA, 2011, p. 268)

$\mathrm{O}$ artista captou muito bem o foco experiencial de Magic Square n. 5 que Paula Braga analisa da seguinte maneira:

Magic Square n. 5 embaralha a noção de tempo cronológico: Stonehenge, templo, labirinto, mas também cenário de um jogo, lazer criativo. Os labirintos públicos deveriam criar uma virtualidade, uma ativação de vivências subjetivas, mas não há como negar a pertinência do termo "virtual" aplicado a Magic Square. (BRAGA, 2011, p. 272)

Eduardo Sued propunha uma interatividade aguçadora dos sentidos com múltiplas possibilidades de acercamentos e vivencias diferente das muitas ditas proposições interativas que se resumem a apertar um botão que quase nunca funciona. À interatividade delegada a eletricidade podemos contrapor a interatividade multissensorial, que cria relacionamentos, era esta ultima que me interessava como experiência para meus alunos. Eu procurava aquilo de que fala Guy Bret (apud BRAGA, 2011, p. 262)

A participação do espectador possui, como todos os rótulos artísticos, o tom frio das frases fáceis. E já foi friamente posto em prática por alguns artistas. Refirome à frieza de todos aqueles objetos e eventos em que a contribuição do espectador é meramente mecânica, em que é apenas recipiente passivo de efeitos preconcebidos ou, de outro modo, de efeitos arbitrários, nos quais não existe potencial para criar relacionamentos. (Guy Bret apud Braga, 2011, p. 262)

O texto de Paula Braga Conceitualismo e Vivência (2008) serviu como roteiro conceitual para a visita que programei ao SESC Pompeia à exposição de Arte para Criança. Na aula seguinte as crianças brincaram com tecidos variados em textura, cor, padronagem,caimento, etc Eram restos de tecidos que sobraram dos Bazares que o Nosso Sonho faz pelo menos duas vezes ao ano para arrecadar dinheiro para se manterem. Os tecidos ganhavam vida entre as cadeiras, no chão, pendurados, amarrados, etc. Vivenciaram novamente grande esforço motor e de percepção.

Depois desta rica experiência começamos a levá-los a pensar na relação figura fundo. Sempre costumo alternar experiências fortemente mobilizadoras com experiências que exigem mais concentração. 
Continuamos com as formas. As orgânicas e as geométricas. Usamos molde vazado e experimentaram tecidos para colar, um material com o qual tiveram experiências muito significativas usando- o em tamanhos grandes. Dessa vez os tamanhos dos retalhos de tecidos eram pequenos Essa experiência das possibilidades do uso da mesma categoria de material em diferentes dimensões os envolveu muito. Curiosamente David Sperling (2011, p.119) nota que a produção de Hélio Oiticica vai da proposição de formas geométricas à proposição de experiências artísticas vivenciais, também os procedimentos que usei com meus alunos seguem uma imbricação semelhante.
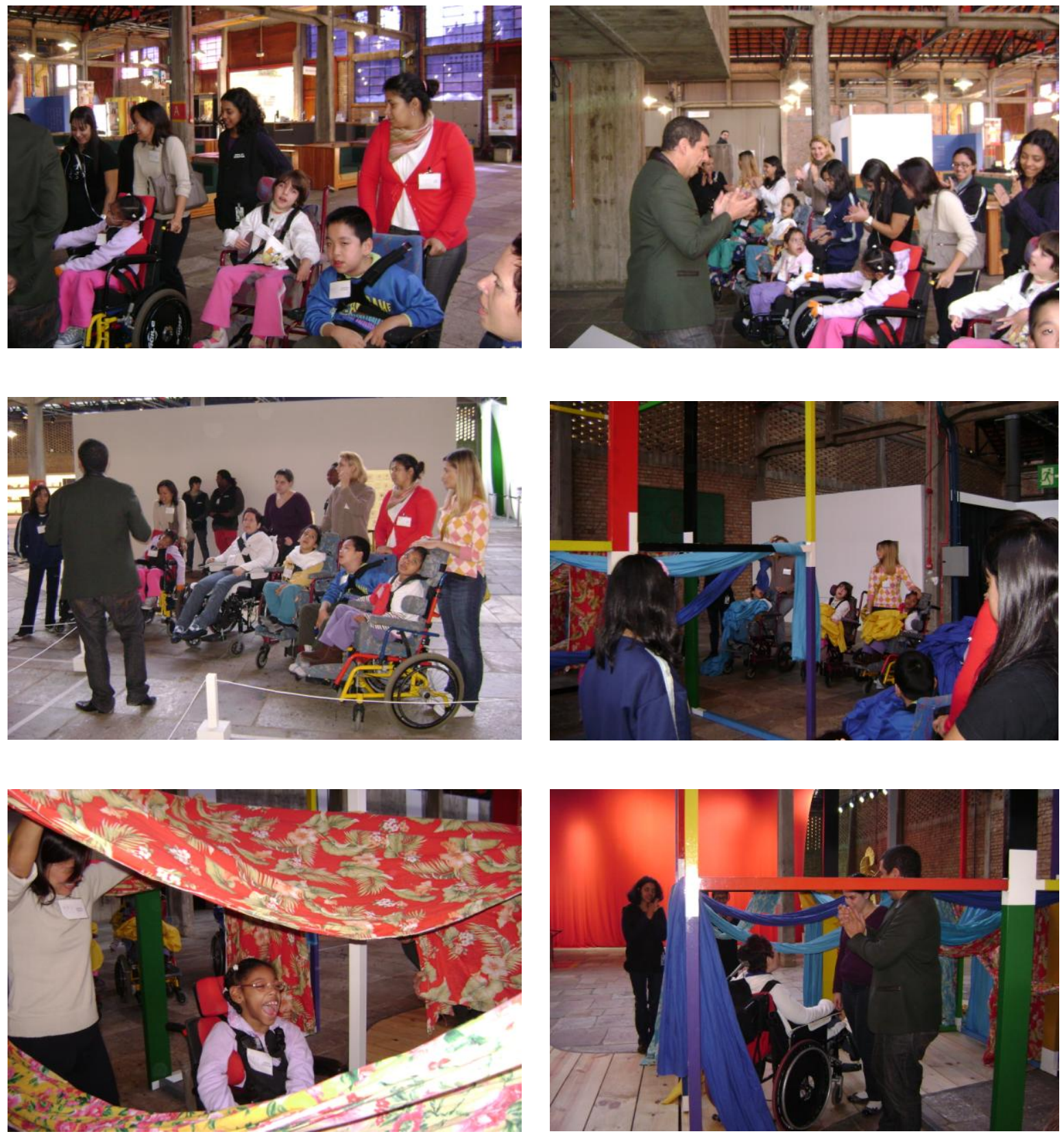

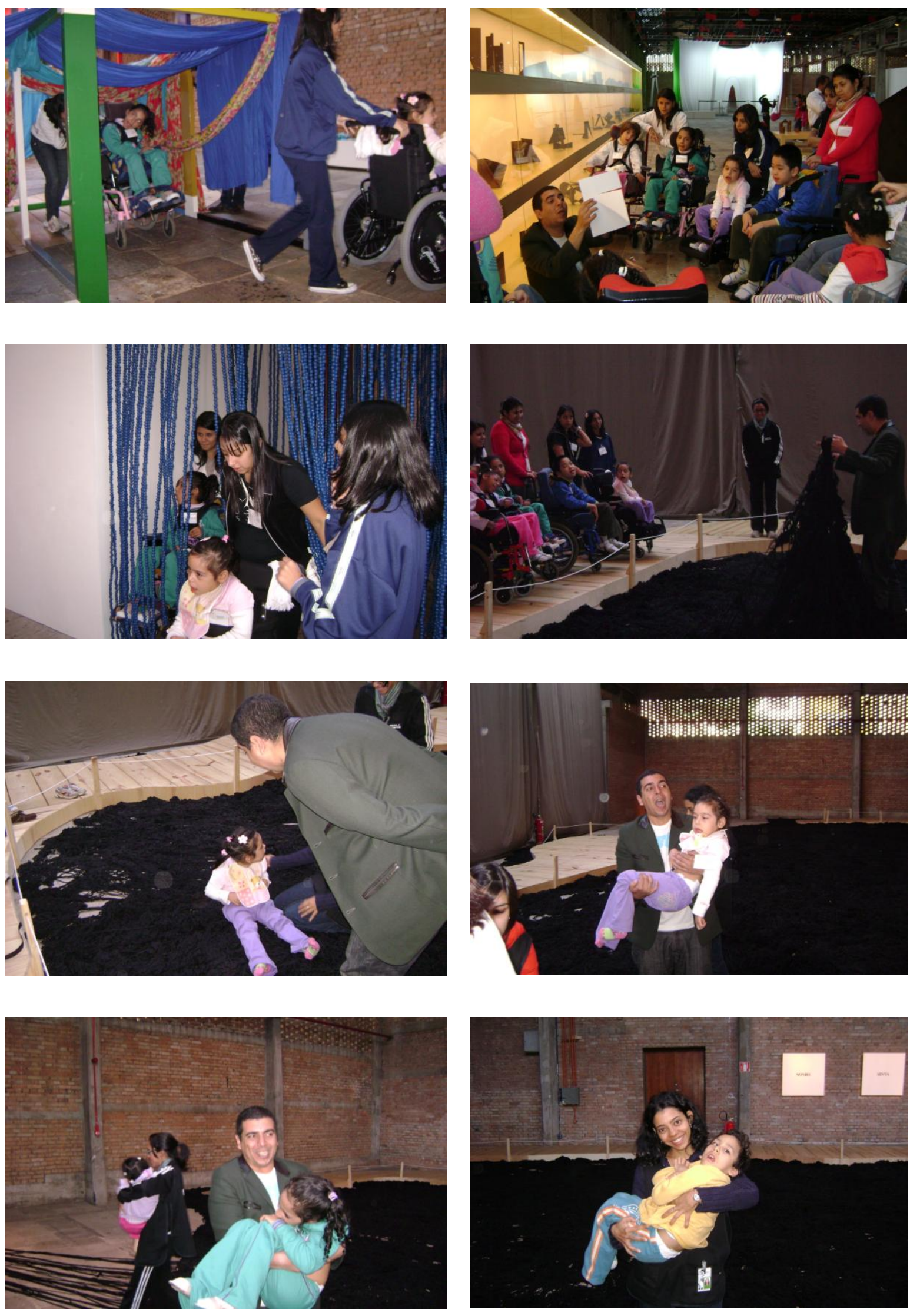

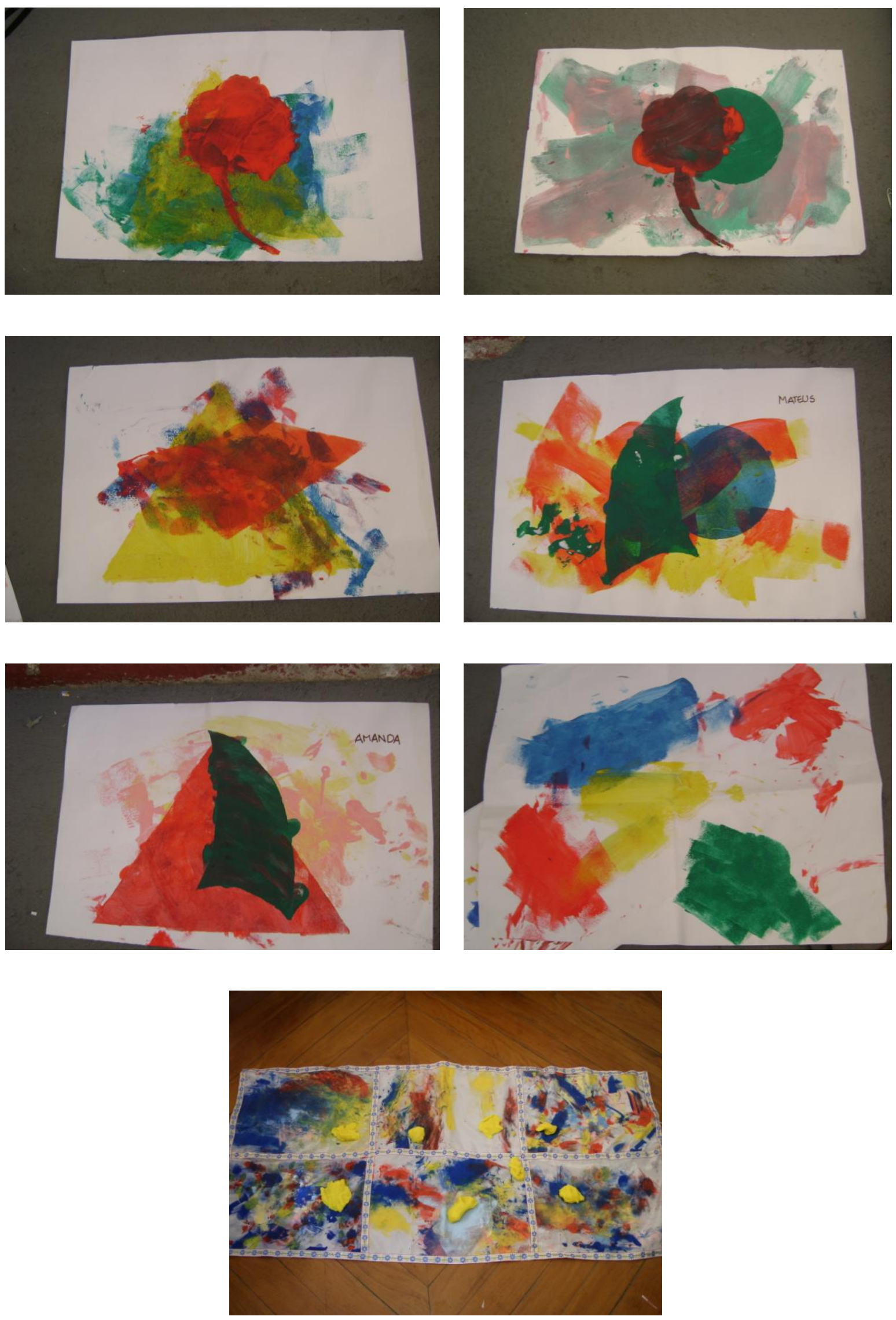
O segundo semestre de 2009 foi bastante conturbado, tivemos poucas aulas.

Em 2010 começamos mexendo com a imaginação, contando histórias. Regina Machado, minha orientadora, com a generosidade que a caracteriza foi contar histórias para eles. Como diz minha filha Ana Lia "Muita gente conta história bem, mas Regina Machado é mágica" Depois das histórias exploramos o tridimensional, com massinha um material já conhecido. Sempre procuro trabalhar primeiro com o conhecido para dar segurança, antes de introduzir um material novo ou pouco usado por eles, como foi o caso posterior do uso da argila, do biscoito e do chocolate que os divertiu muito.

No trabalho com argila, primeiro fizemos as impressões das mãos e dos pés e pintamos. Retomamos na aula seguinte as impressões em argila dos pés e das mãos, dando-as de presente aos pais.
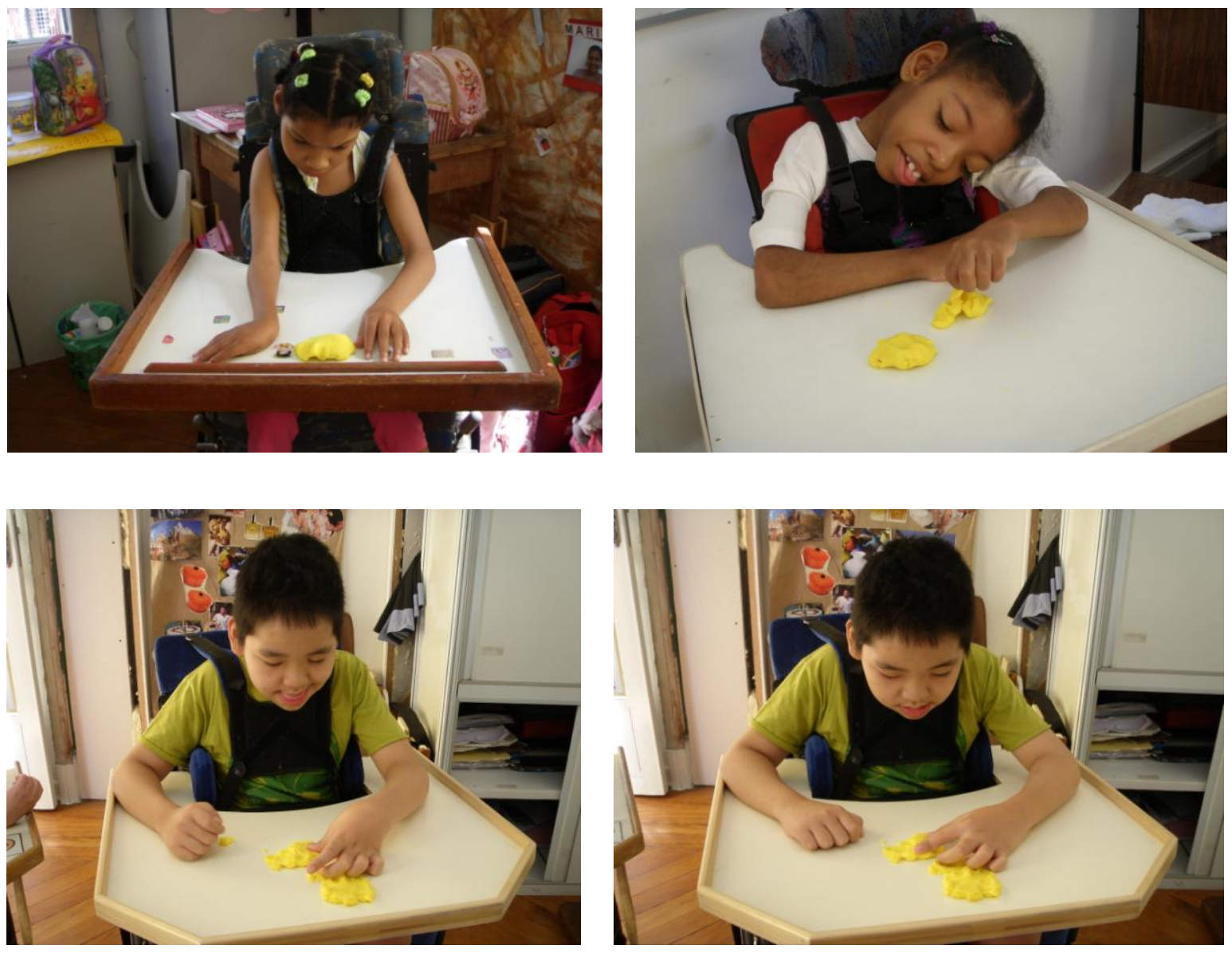

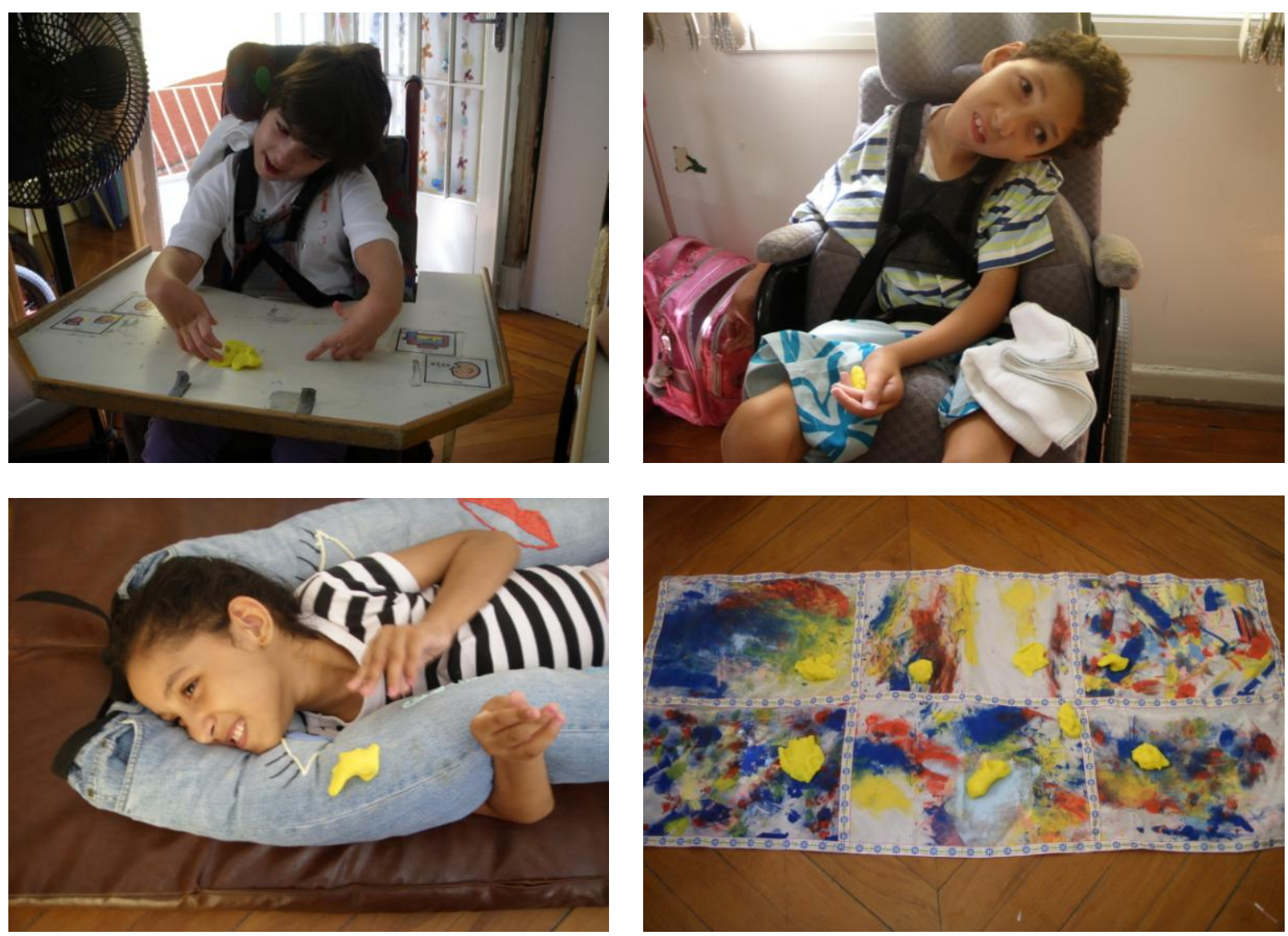

Depois fizemos uma escultura abstrata com argila, usando as mãos e pintamos também.

A preocupação era a questão do volume sem deixar de lado a incorporação da cor já muito experimentada. A intimidade com volume de pequenas dimensões que pudesse ser dominado por suas mãos e pés, portanto por seus corpos já estava preparando para a experiência que se seguiu: a ida ao Jardim das Esculturas do Parque da Luz para experimentar o volume em grandes dimensões.

$25 / 02 / 2010$

JAH ME EMOCIONEI VARIAS VEZES, MAS ESSA FOI FUN$\mathrm{DO} !$

ESSA SEMANA EU TAVA DANDO AULA E, DEPOIS DE MEXER COM TINTA, UMA ALUNA TETRA, MUDA, QUASE CEGA E MUITO ESPÁSTICA DEU UMA GARGALHADA!!! (http://amaliabarbosa.zip.net) 
O planejamento de atividades que coloque em foco o corpo social na sua dupla acepção já havia começado a ocupar meu planejamento desde a ida á exposição para crianças do SESC.

Segundo Suzi Weber (Mestra pela Université du Québec à Montreal (UQAM) e Doutoranda do Departamento de Teatro da Universidade Federal do Rio Grande do Sul) a primeira acepção de corpo social "refere-se à dimensão do corpo na qual é possível ler as inscrições e marcas sociais e está ligado à ideia que o corpo é construído pela sociedade. É ela que vai definir o corpo ideal ou as diferentes hierarquias de modelos de corpos.” (Weber, 2006, p. 22, 23)

O segundo sentido de corpo social se refere aos modos de interação com grupos sociais e comunidades. É a inter-relação dos dois sentidos de corpo social que motivou nossa ida ao Jardim de Esculturas do Parque da Luz, onde sabia que iriam encontrar muitas pessoas de diferentes classes sociais. Nos museus encontramos uma classe social para a qual somos invisíveis. É bem educado fingir que não se vê o corpo fisicamente deficiente. Nos shoppings centers uma cadeira de rodas faz algumas pessoas olharem com curiosidade, mas é na rua e nas praças que o povo se aproxima e pergunta a razão da diferença para melhor incorporá-la.

A sociologia vem estudando o corpo social sob diversos pontos de vista desde a imposição do poder político até a imposição capitalista da moda.

Interesso-me principalmente pelos modos de resistência do "corpo sofrimento" individual, em relação às negações sociais. Como potencializar "profundas transformações no modo de produção da existência coletiva e individual, as quais multiplicam não apenas os atores sociais envolvidos na luta de resistência, mas também as possíveis estratégias e lugares de intervenção criativa"(Carlos Augusto Peixoto Junior, 2008, p. 58) Como estimular a superação da inscrição do modelo social de corpo por um corpo individual em constante experimentação em direção a reinvenção? Como dialogar com o corpo social relativizando o impacto da diferença que a sociedade não quer ver?
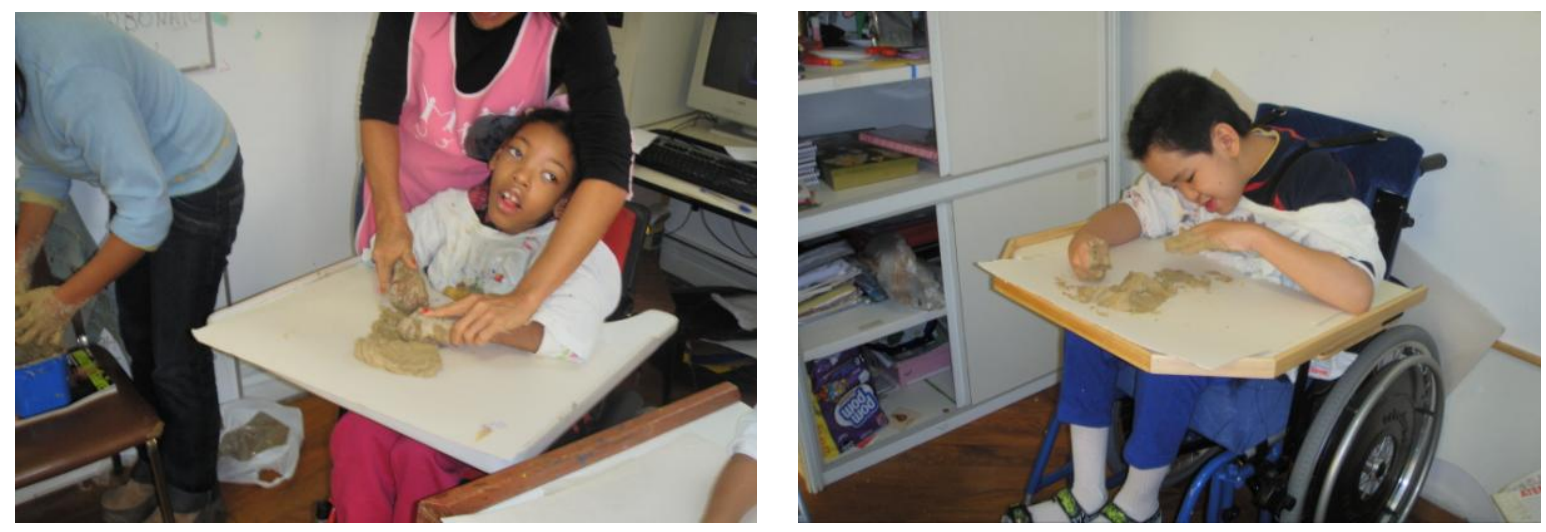

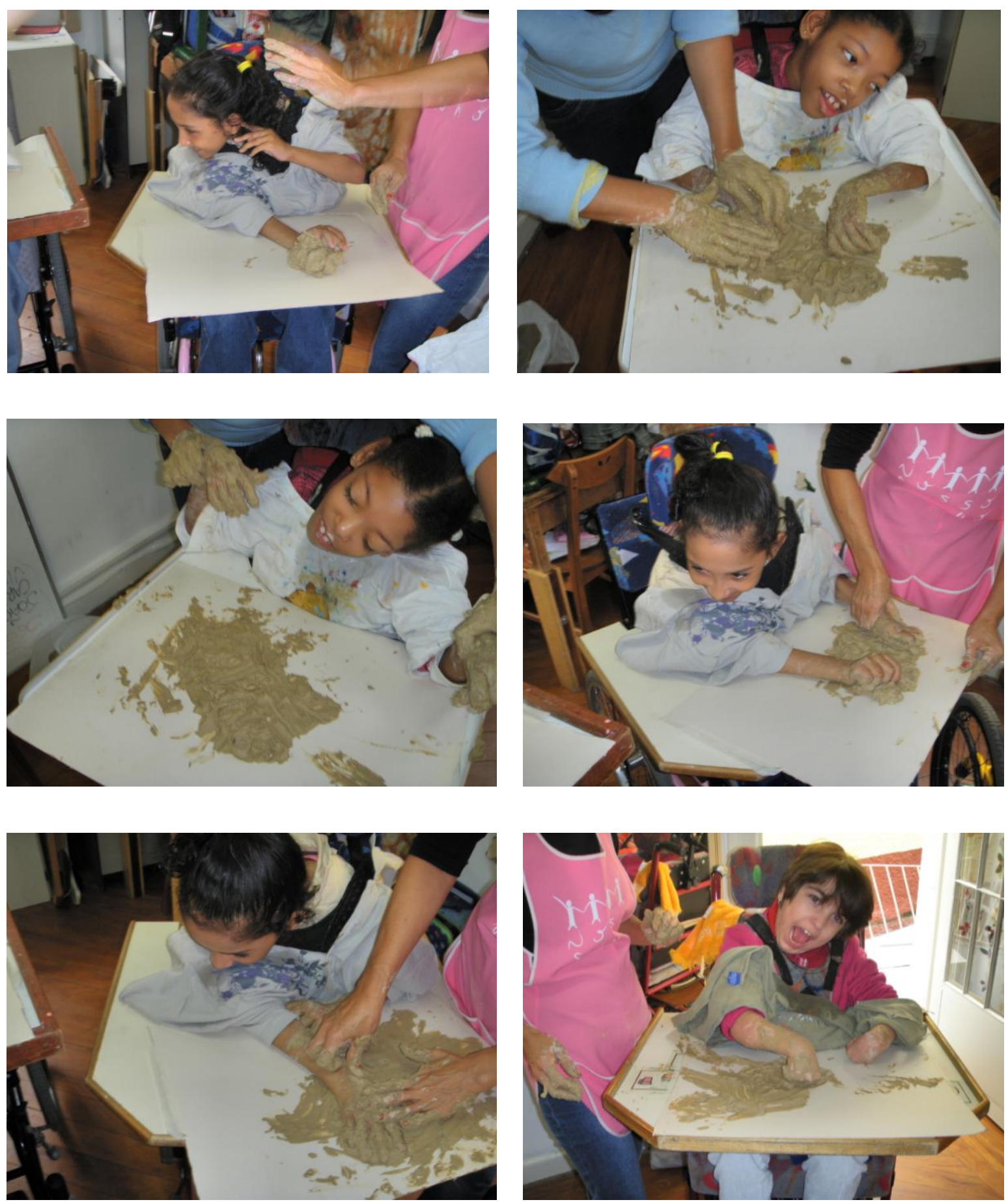

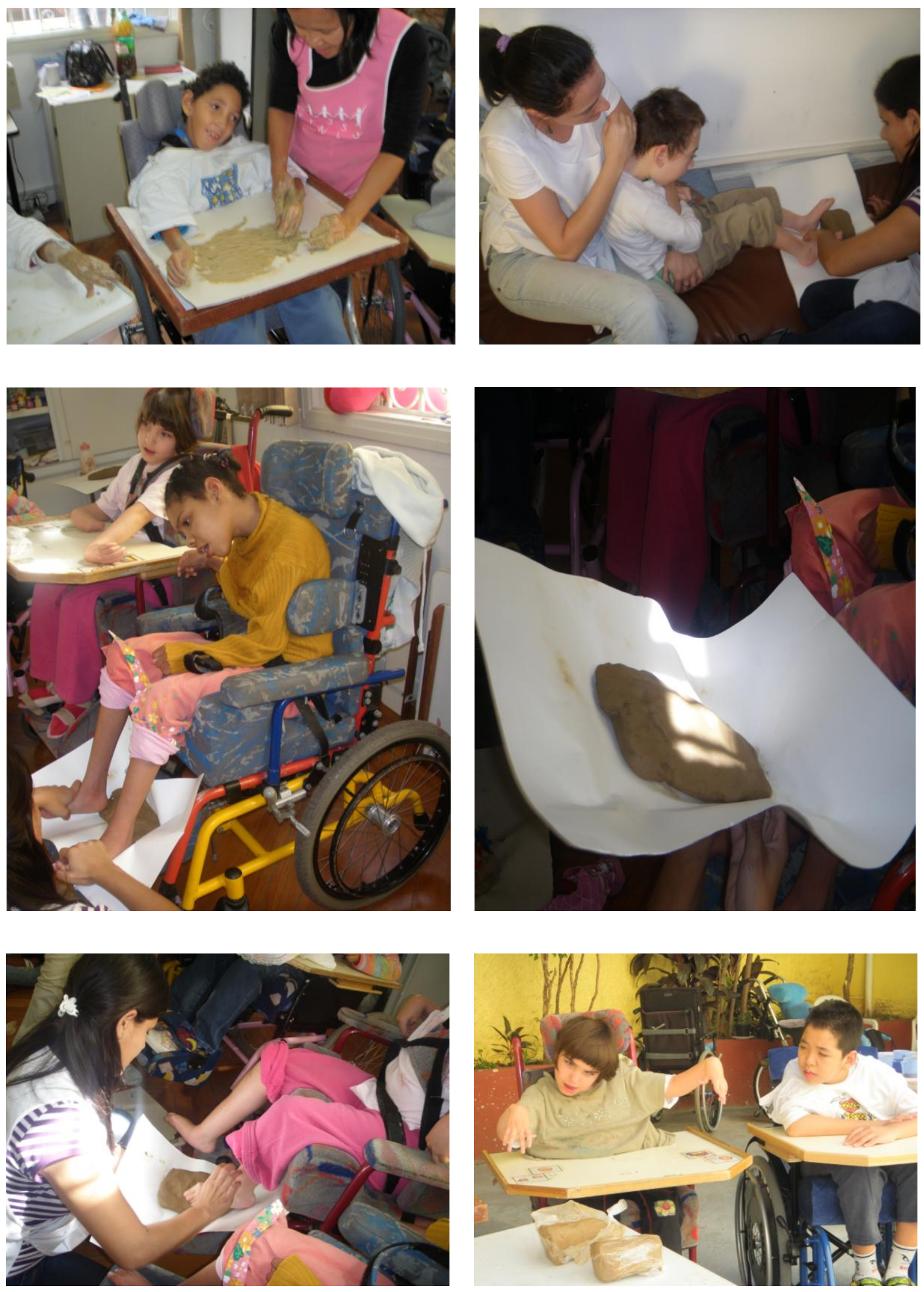

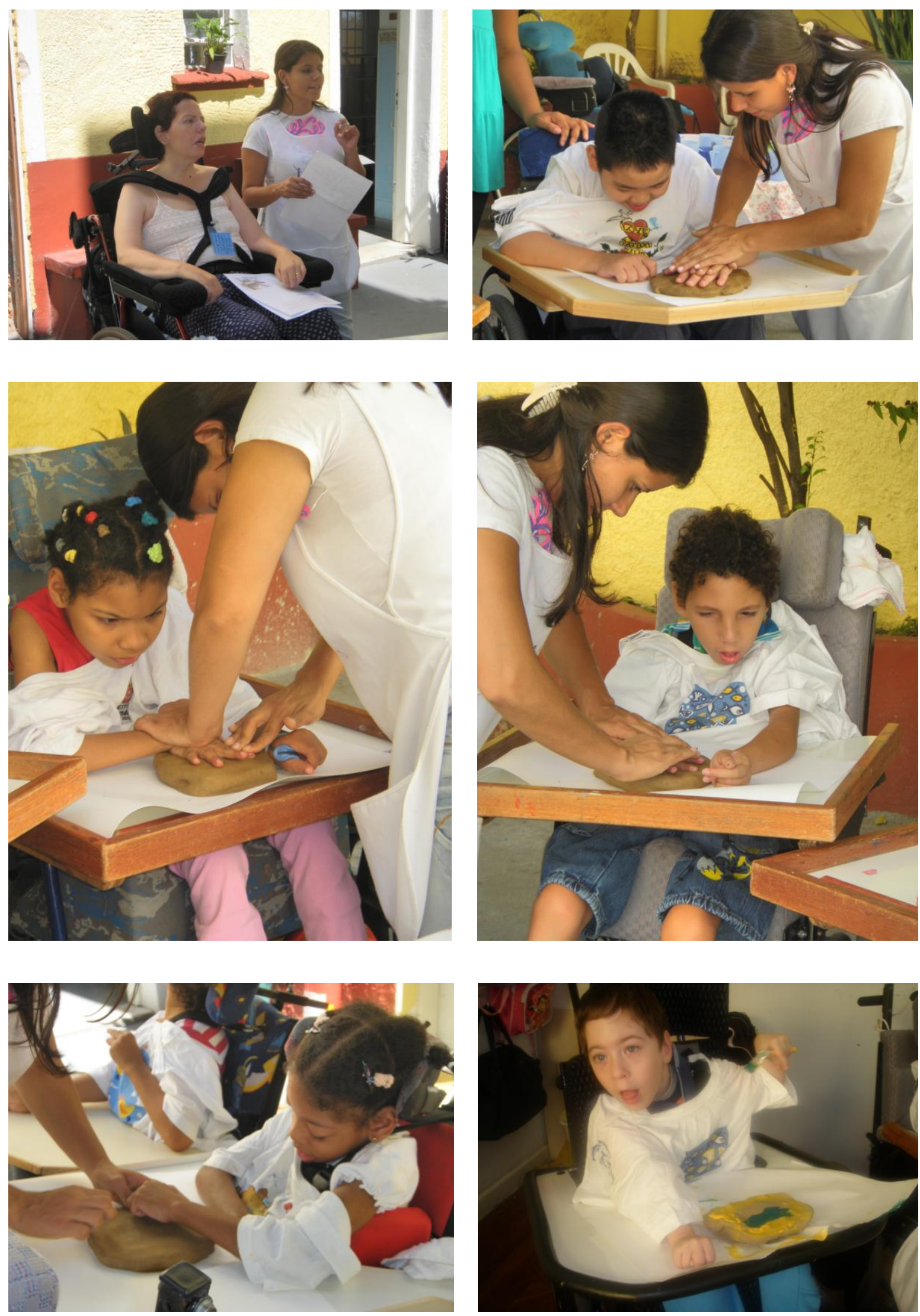

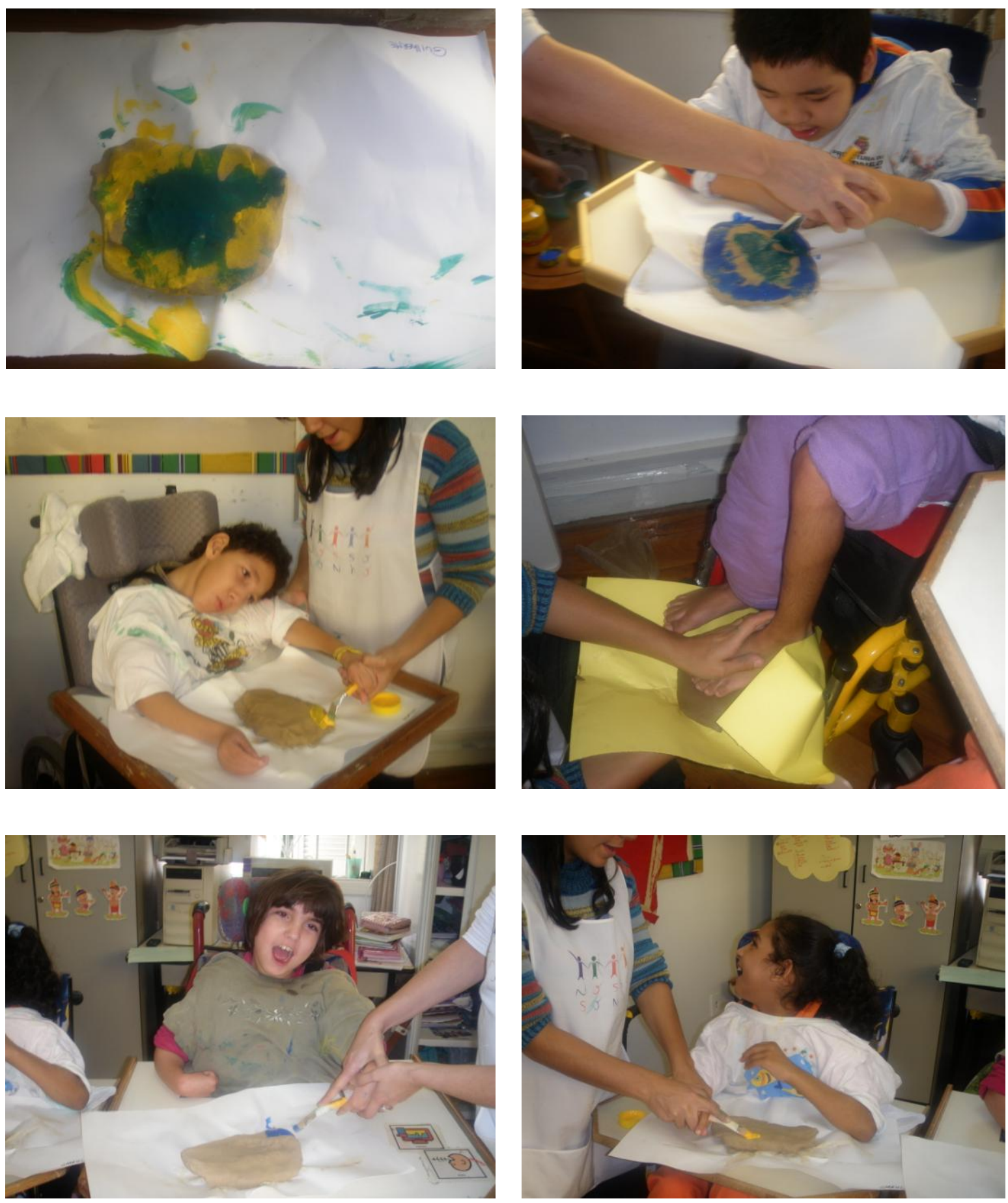

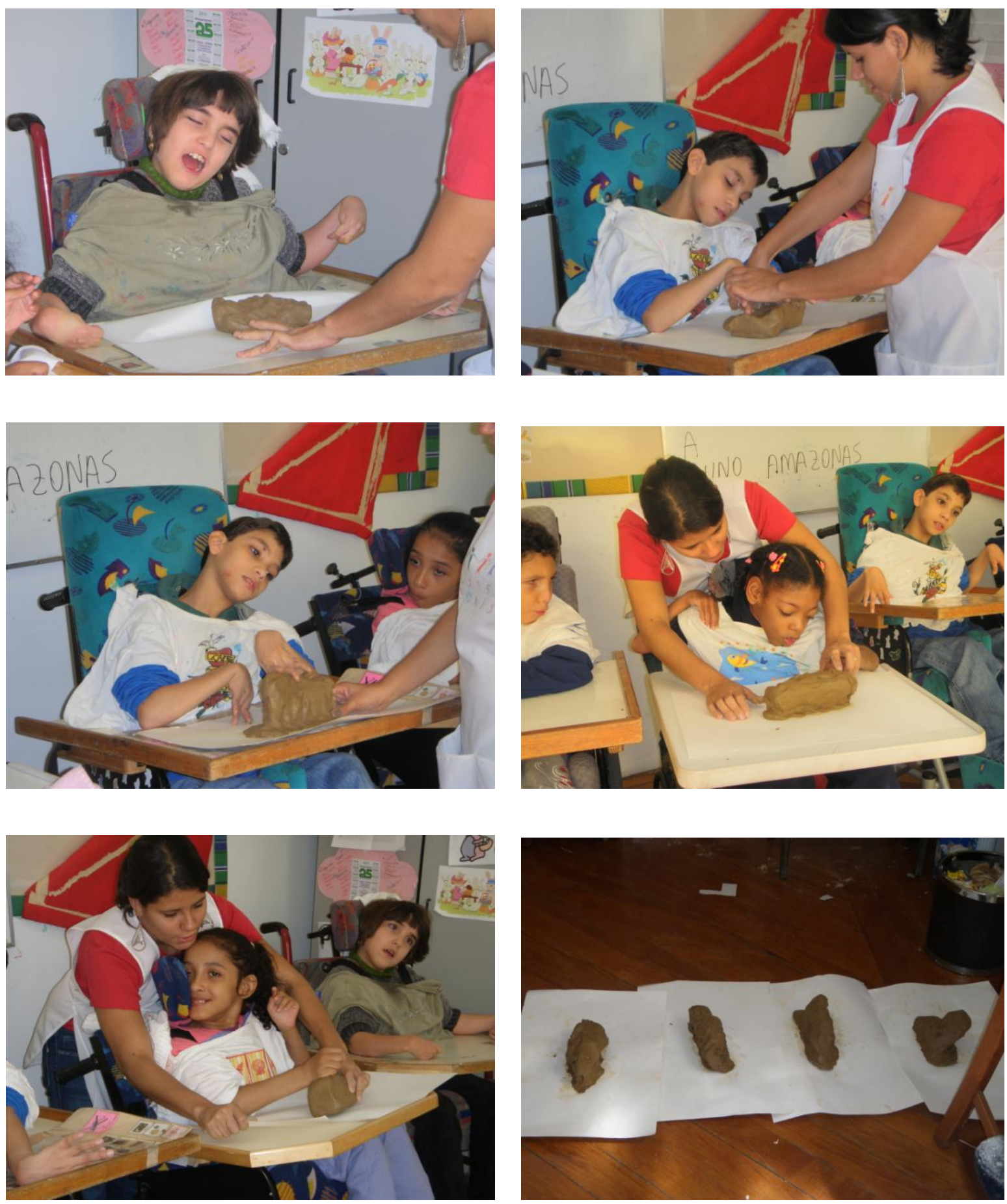

$25 / 03 / 2010$

ABSURDO

SOU PROFESSORA DE ARTES DE UM GRUPO DE CRIANÇAS CADEIRANTES, ASSIM COMO EU. 
ESTAMOS PROGRAMANDO UMA VISITA AO JARDIM DAS ESCULTURAS NO PARQUE DA LUZ, A ESCOLA FICA EM PERDIZES. SIMPLES! VAMOS DE TREM!

AO PROGRAMAR UMA VISITA EU GOSTO DE FAZER, ANTES, O TRAJETO PARA EVITAR TRANSTORNOS. QUERIA QUE AS CRIANÇAS FOSSEM DA ESTAÇÃO BARRA FUNDA À ESTAÇÃO DA LUZ DE TREM, ESSA EH UMA EXPERIÊNCIA QUE TODO PAULISTANO DEVERIA TER, MAS... APESAR DE TEREM INDICAÇÃO DE ACESSIBILIDADE, OS TRENS SÃO INACESSÍVEIS. TENTEI PEGAR O TREM, MAS OS TRÊS QUE PASSARAM NÃO TINHAM COMO ENTRAR POIS A DISTÂNCIA ENTRE A PLATAFORMA E O TREM ERA ENORME. ACHAVA QUE ISSO JAH TIVESSE SIDO RESOLVIDO MAS PARECE QUE NÃO! FUI DE METRÔ, NÃO EH A MESMA COISA!

NÃO ENTENDO PQ OS CADEIRANTES NÃO TEM OS MESMOS DIREITOS DOS ANDANTES, A ÚNICA DIFERENÇA EH A CADEIRA SOMOS TODOS HUMANOS! (http://amaliabarbosa.zip.net)

$19 / 04 / 2010$

CPTM

ASSIM COMO TODO PROFESSOR EU PREPARO AS MINHAS AULAS, ESPECIALMENTE UM "ESTUDO DE CAMPO”. A DIFERENÇA EH QUE ANTES DE LEVAR AS CRIANÇAS, EU TESTO A ACESSIBILIDADE DO LOCAL. 
ESSA SEMANA EU FUI AGRADAVELMENTE SURPREENDIDA PELA CPTM.

A PESSOA RESPONSÁVEL PELO EDUCATIVO ORGANIZOU UMA VISITA PARA MIM.

FOMOS EU, MINHA ENFERMEIRA E UM AMIGO/PROFESSOR QUE SEMPRE NOS ACOMPANHA ÀS VISITAS, A RESPONSÁVEL PELO EDUCATIVO E O RESPONSÁVEL PELA ACESSIBILIDADE, MAIS DOIS

SEGURANÇAS. ELES TEM UMA EQUIPE TREINADA PARA FACILITAR A ACESSIBILIDADE, MESMO ONDE ELA NÃO EH OBVIA, SOH NÃO ENTENDO COMO NÃO ATUARAM NO DIA QUE FUI SOH.

O PRIMEIRO VAGÃO TEM LUGAR PARA CADEIRA E O MAQUINISTA CONSEGUE VER SE O CADEIRANTE JAH EMBARCOU. OS TRENS MAIS NOVOS TEM UMA ESPECIE DE PARAPEITO NAS PORTAS, MAS MESMO

QUANDO NÃO TEM DAH PRA ENTRAR NO VAGÃO, SE PRECISAR ELES CARREGAM A CADEIRA.

CHEGAMOS À LUZ! O ELEVADOR AINDA ESTAH EM CONSTRUÇÃO ENTÃO DESCEMOS DE ESCADA ROLANTE ESSA FOI A ÚNICA PARTE EM QUE FIQUEI APREENSIVA, MAS EH TÉCNICA E ELES A TEM. DAIH 
PEGAMOS O ELEVADOR DO METRÔ E SUBIMOS, ATRAVESSAMOS A RUA E ENTRAMOS NO PARQUE E ESCOLHEMOS AS ESCULTURAS QUE VAMOS TRABALHAR COM AS CRIANÇAS.

ELES ME PROVARAM QUE EH POSSÍVEL! (http://amaliabarbosa.zip.net)

$18 / 05 / 2010$

HOJE O CAITO FOI DAR AULA PRAS CRIANÇAS, SEMANA PASSADA FOMOS AO JARDIM DAS ESCULTURAS NO PARQUE DA LUZ (TAVA MUITO FRIO, O TAXI ACESSIVEL "ME DEU O CANO" E A CIDADE ESTAVA UM CAOS PRA COMPLETAR A AUXILIAR ESTAVA DOBRANDO PLANTÃO). ENTRE OUTRAS, VIMOS A ESCULTURA DO CAITO.

ADORO AQUELAS CRIANÇAS, ELAS NÃO FALAM COM A BOCA E NEM SE MEXEM, MAS OS OLHOS NÃO PARAM, ESSA CURIOSIDADE DELES EH TÃO BONITA! ME DAH FORÇA PRA ENFRENTAR O FRIO. EU FICO PENSANDO QUE ELES TEM QUASE A MESMA IDADE DO MEU AVC MAS ELES NASCERAM ASSIM ENTÃO EH MINHA TAREFA, OBRIGAÇÃO, MISSÃO, MOSTRAR QUE DAH PRA VIVER BEM SEM ANDAR OU FALAR. EU ENSINO ARTE, MAS TÔ COMEÇANDO A ACHAR QUE ARTE EH APENAS A PONTA DO ICEBERG, NO FUNDO VOU MAIS LONGE. 


\section{PODERIA, PERFEITAMENTE, DAR AS AULAS VIRTUAL- MENTE, MAS NÃO SERIA A MESMA COISA! (http://Amália- barbosa.zip.net)}

Foi uma longa caminhada, mas fomos ao Jardim das Esculturas (vide dvd anexo) e discutimos a questão do volume frente as obras de Liuba, Caito, Ligia Reinach e Carlito Carvalhosa. A dimensão do corpo em relação às esculturas também foi explorada.

Lembro que saber ler uma imagem é tão importante quanto produzir uma, porque ambas as atividades desenvolvem o processo criador e alimentam a consciência cultural.

Analice Dutra Pillar assim explica o processo de leitura:

... ler contemporaneamente é atribuir significado seja a uma imagem, seja a um texto. Nelson Goodman, filósofo norte-americano e fundador do Projeto Zero de Harvard, diz que "o modo como se lê" um rabisco depende do contexto em que ele se encontra, do marco gráfico que rodeia e do contexto mental do observador (GOODMAN apud GARDNER,1987, p.76-77) Assim um rabisco num desenho de criança tem um significado,num mapa tem outro, num texto tem outro.

O sentido vai ser dado pelo contexto gráfico e pelas informações que o leitor tem. Ao ler estamos entrelaçando informações do objeto, suas características formais, cromáticas, topológicas e informações do leito,,seu conhecimento acerca do objeto, suas inferências, sua imaginação. Assim, a leitura depende do que está em frente e atrás dos nossos olhos (PILLAR, 2010, p. 8).

A produção de imagens ou o fazer artístico são alimentados pela experiência do sujeito em ver imagens e ver Arte.

João Cabral de Mello Neto poeticamente se refere à pintura como sucessão de pinturas ou ao processo criador em Arte como sucessão de portas e corredores que dão em outras portas e outros corredores.

\section{A Lição De Pintura}

\section{Quadro Nenhum Está Acabado}

Disse Certo Pintor

Se Pode Sem Fim Continuá-Lo, 
Primeiro, Ao Além De Outro Quadro

Que Feito A Partir De Tal Forma,

Tem Na Tela, Oculta Uma Porta

Que Dá A Um Corredor

Que Leva A Outra E A Muitas Outras

João Cabral De Mello Neto (Museu De Tudo, 1966-1974)
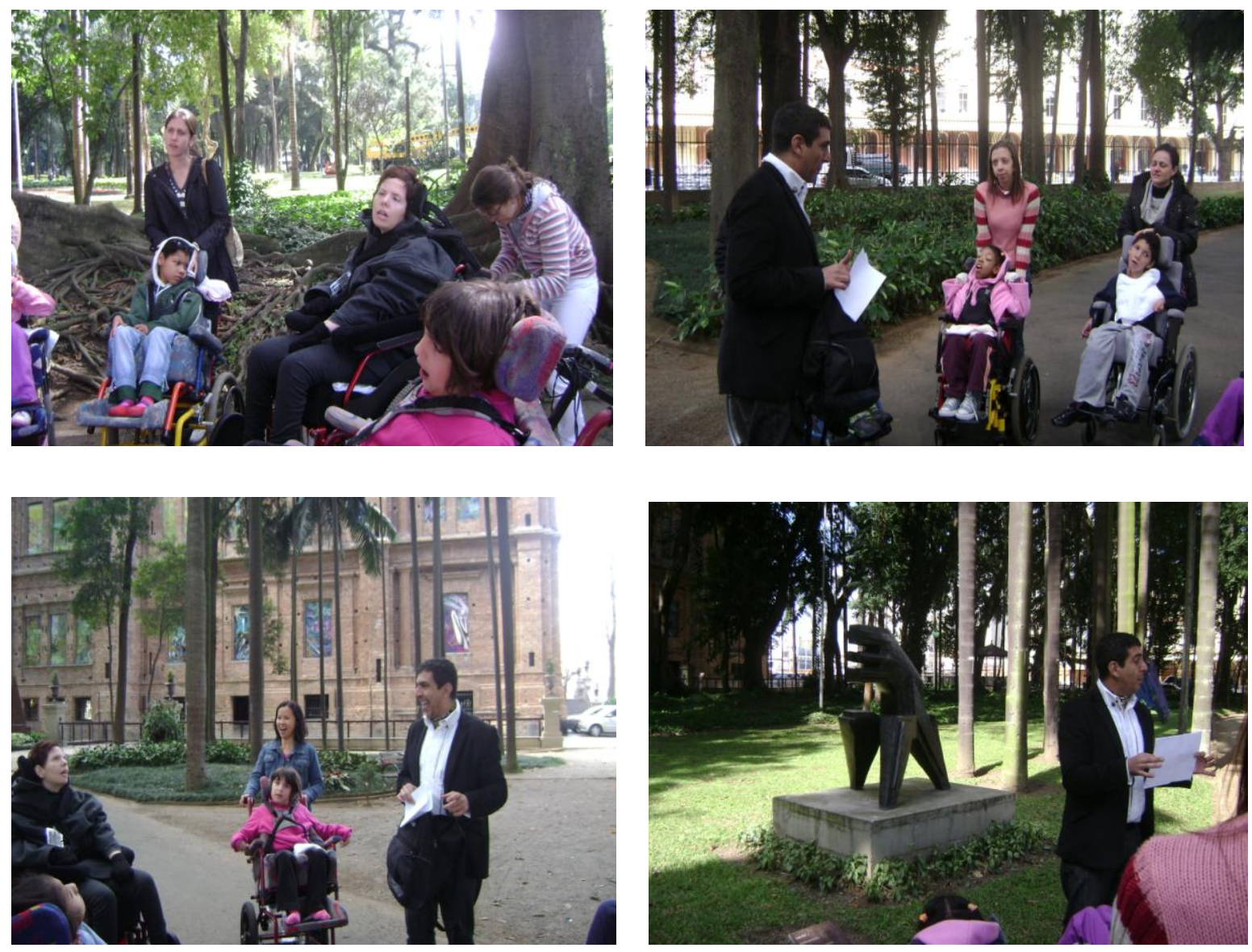

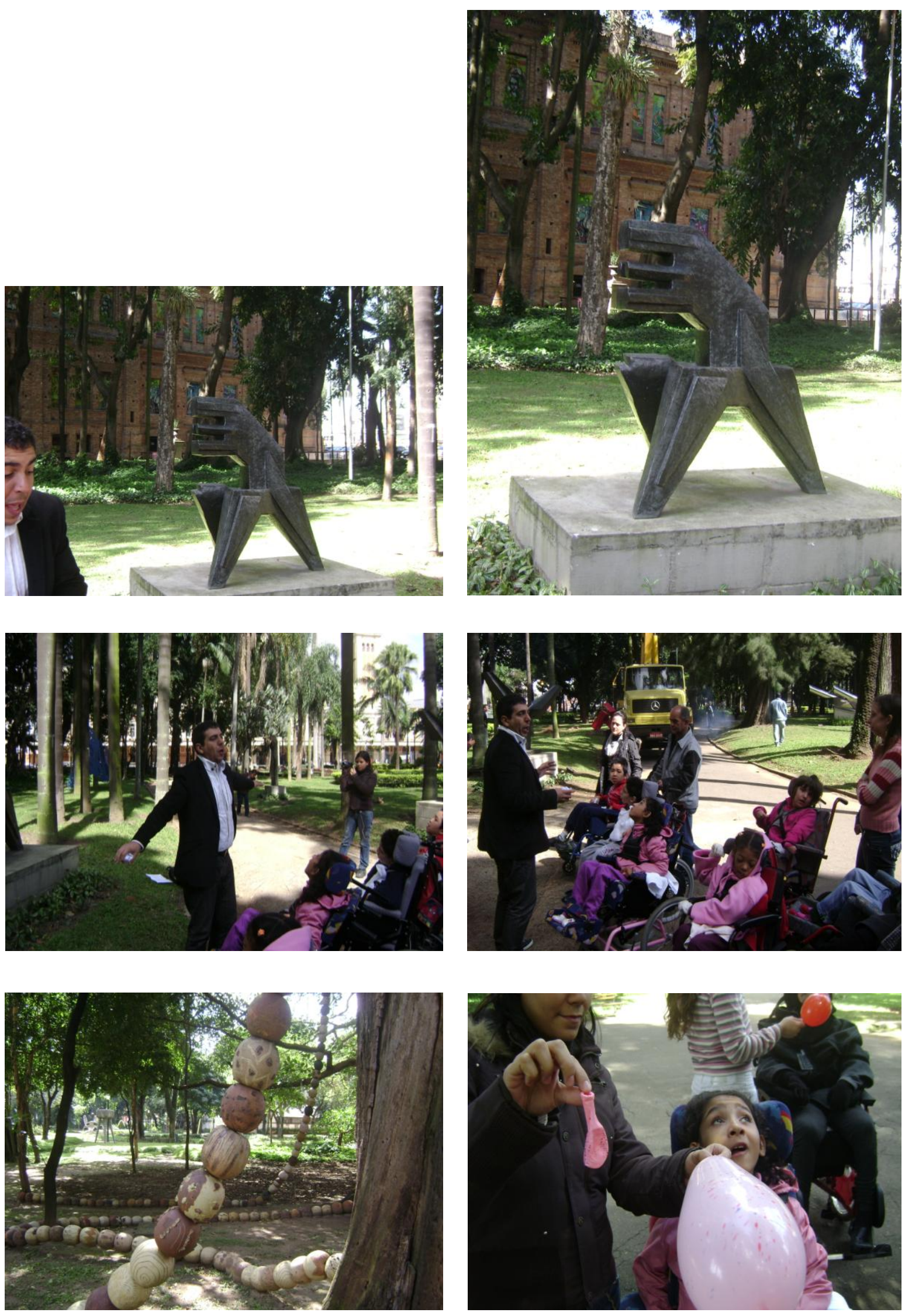

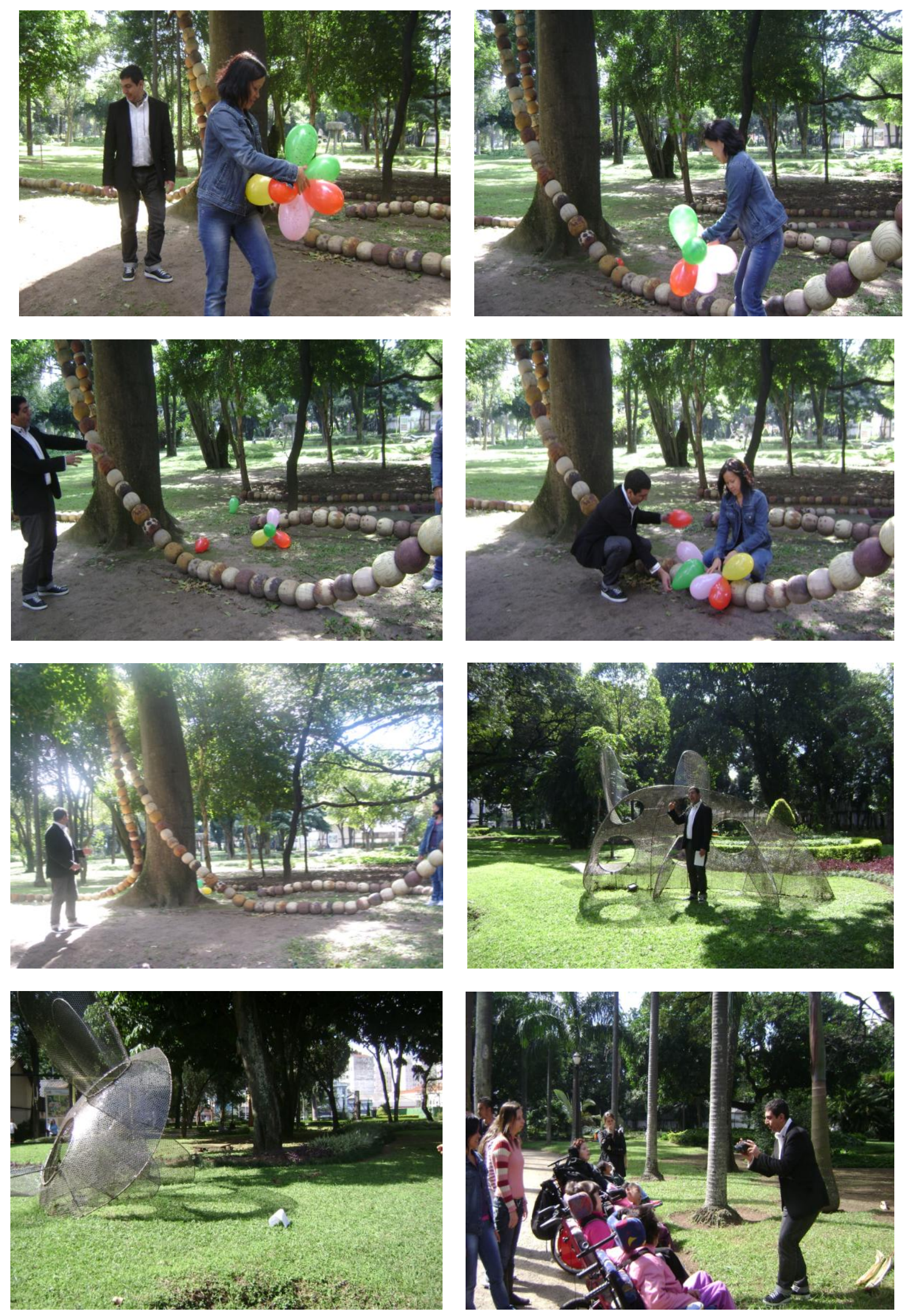

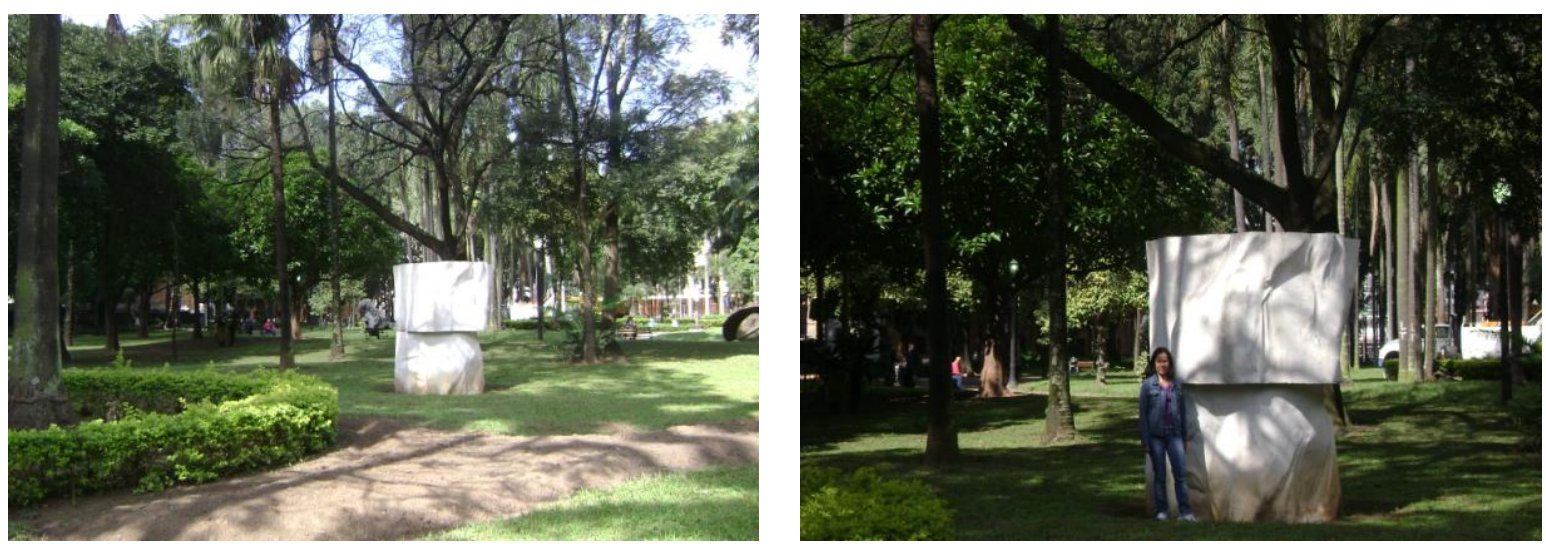

Após a visita ao Jardim das Esculturas tivemos uma aula com um dos artistas cuja obra havíamos visto. Caito propôs uma atividade com massa de biscoito e no final, literalmente a la Oswald de Andrade, comemos nossos biscoitos/esculturas.
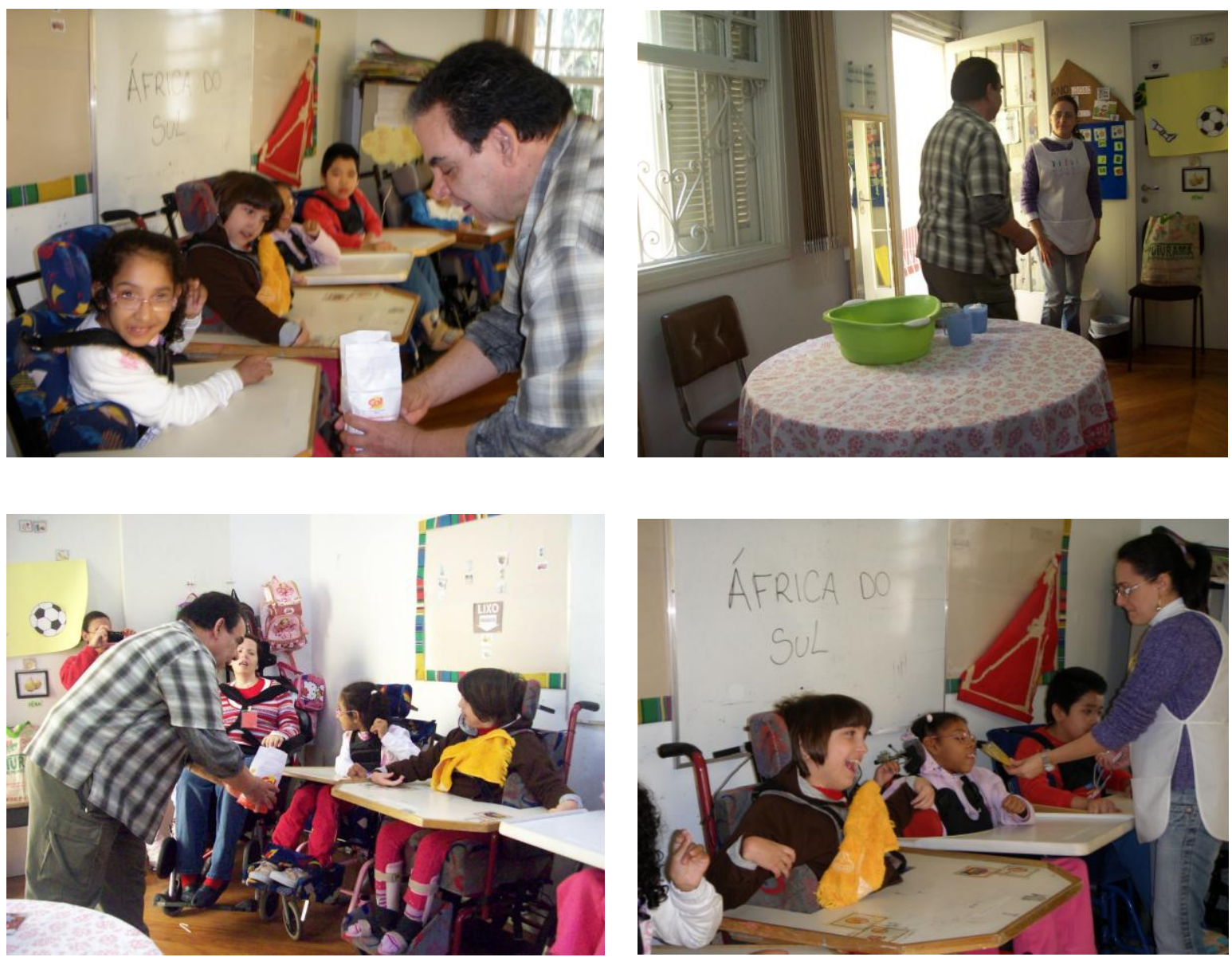

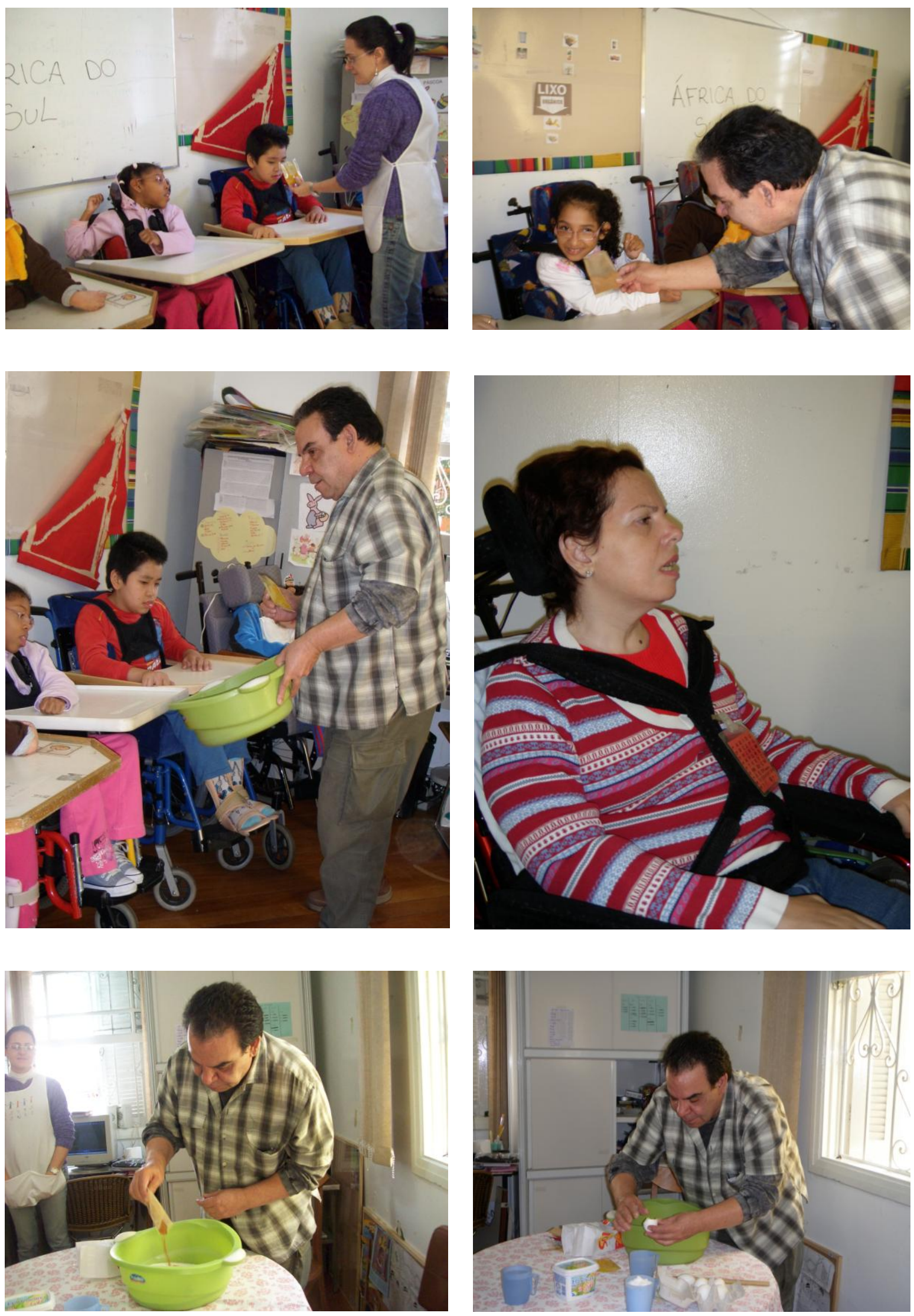

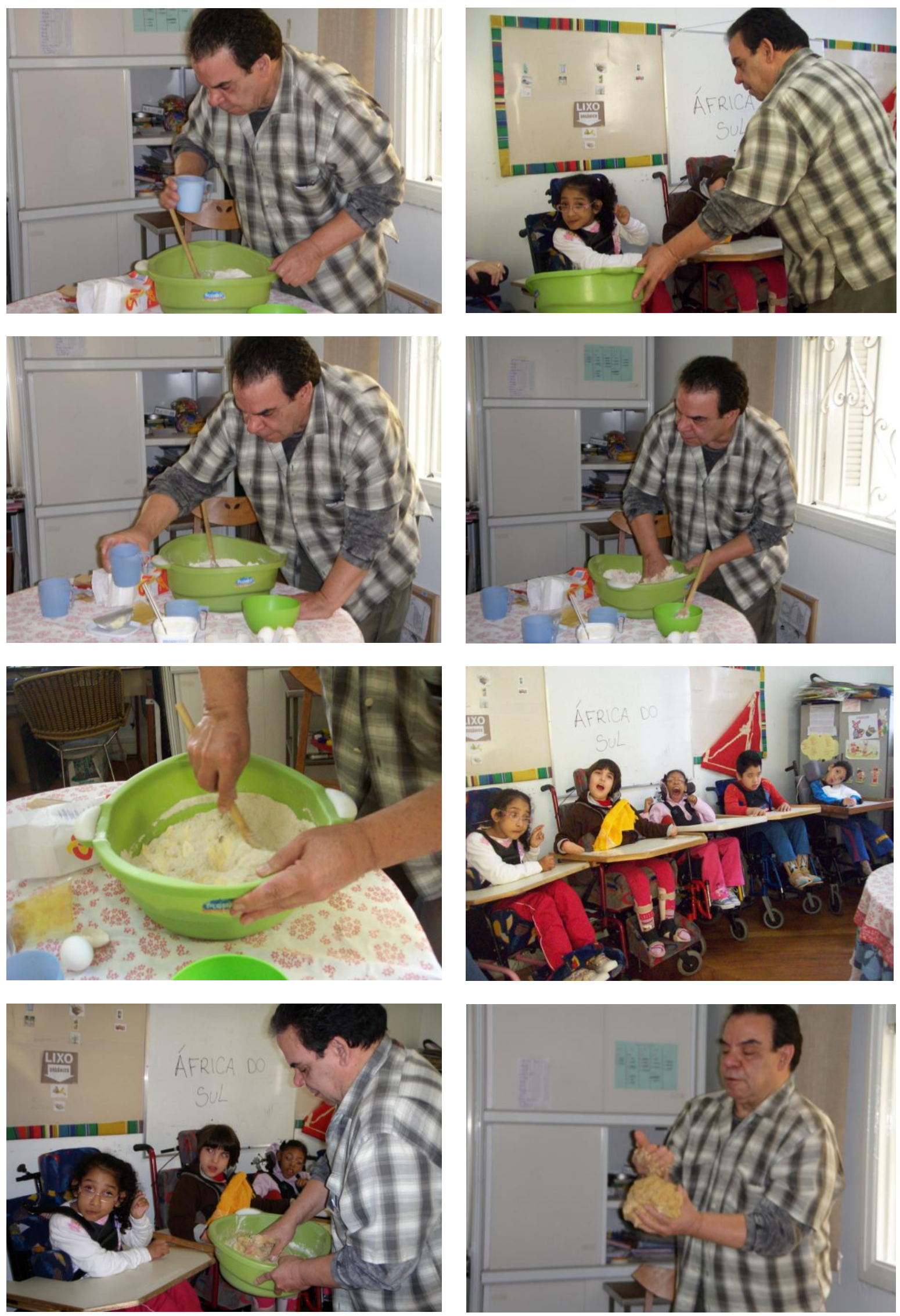

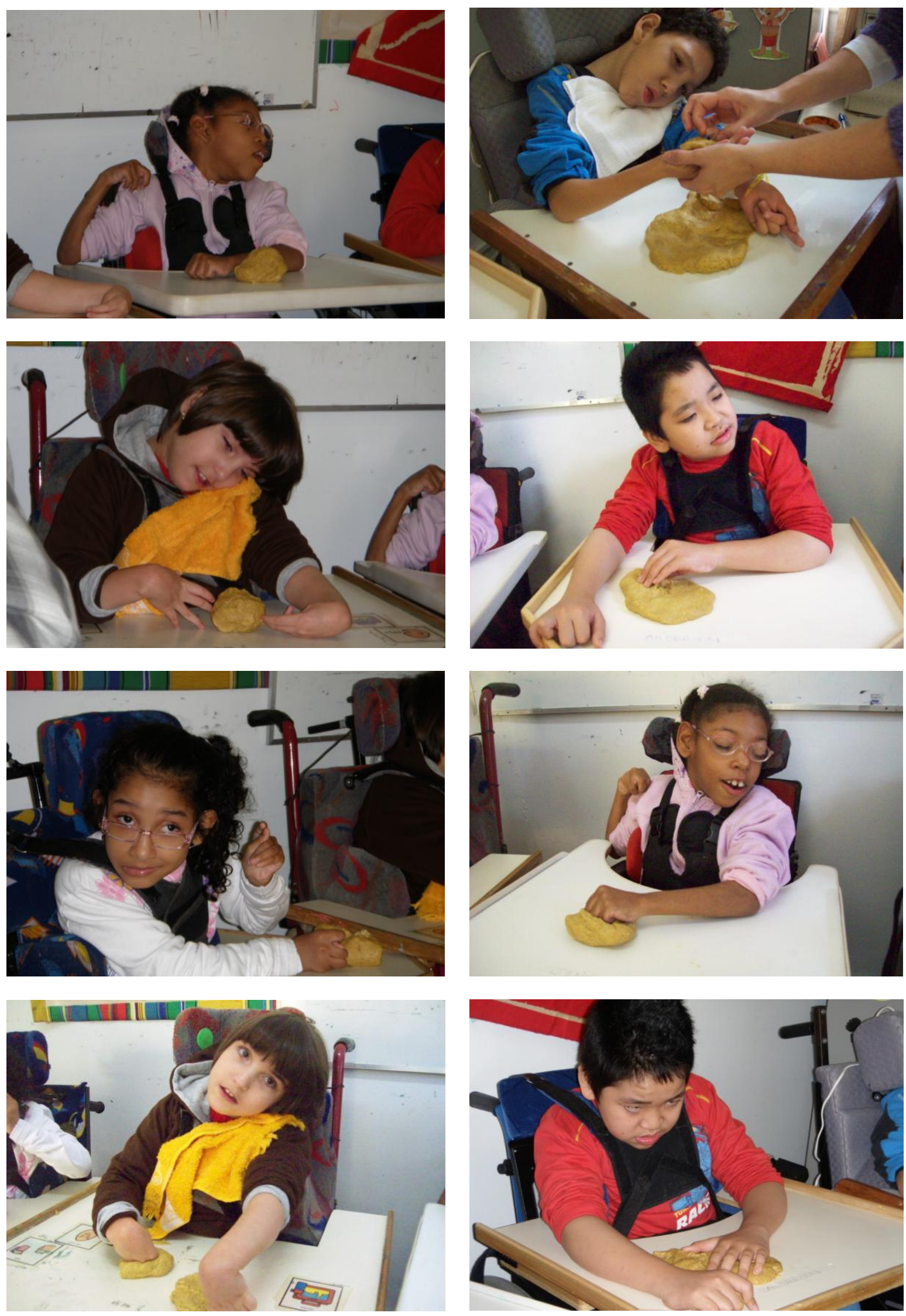

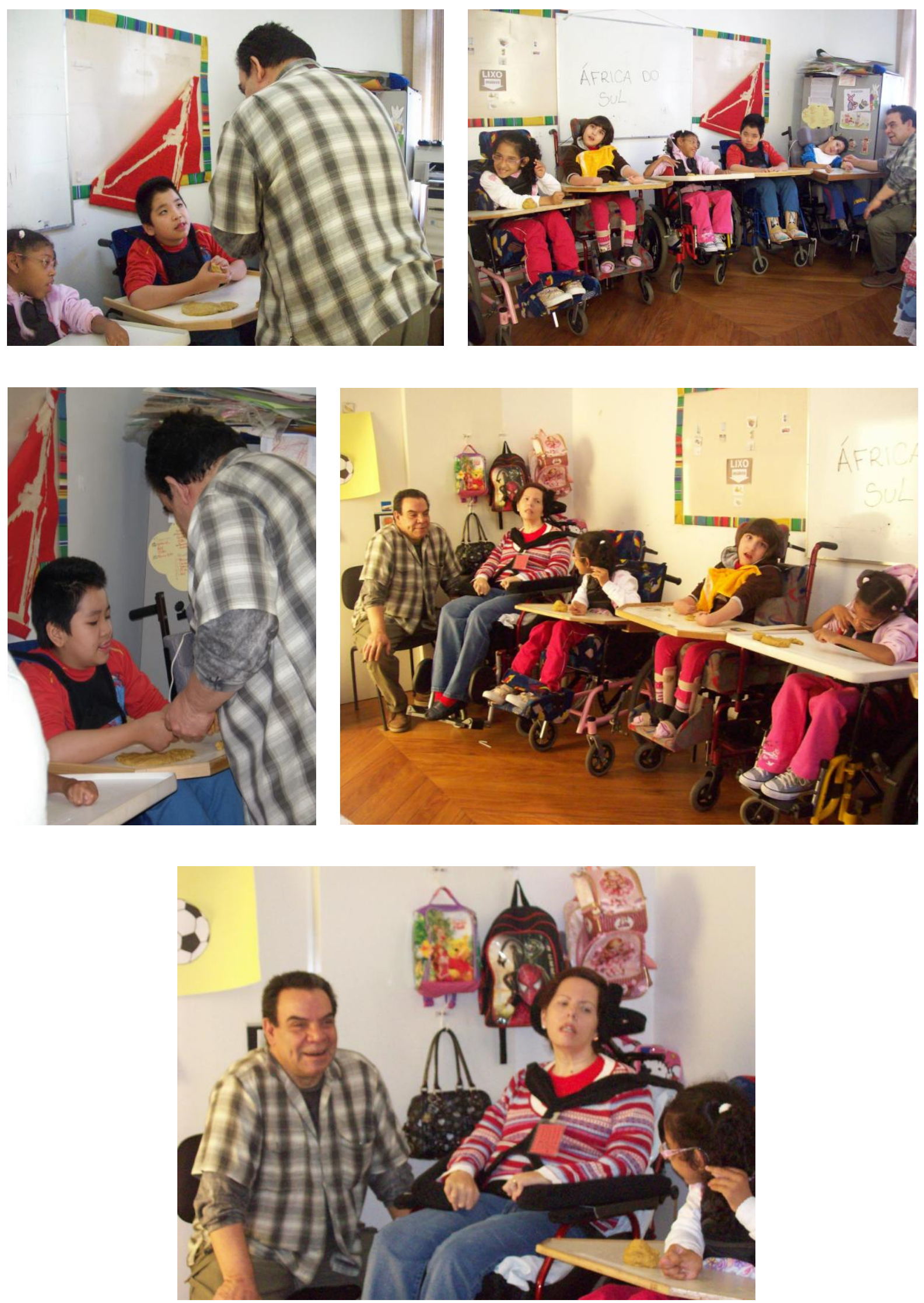

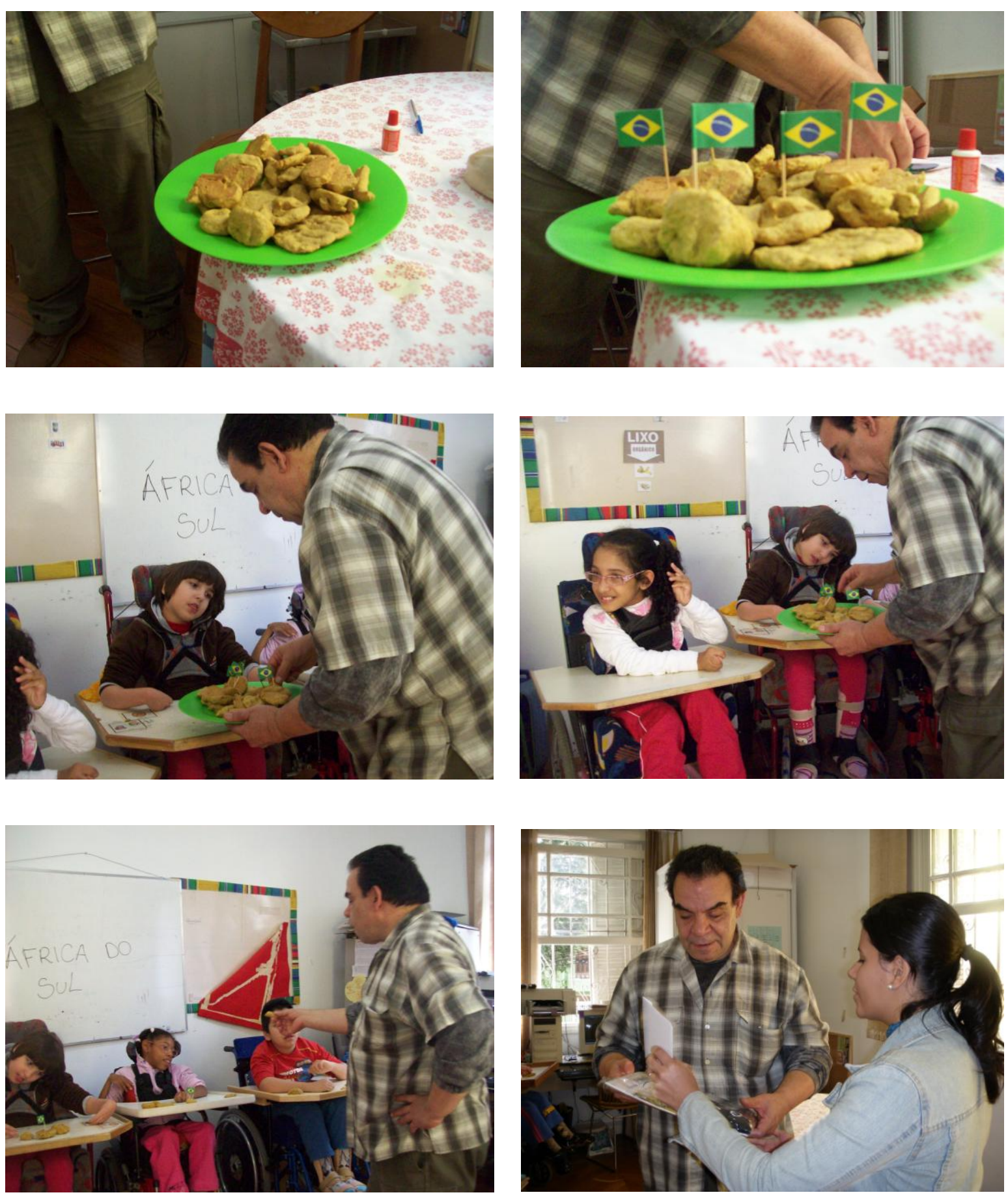

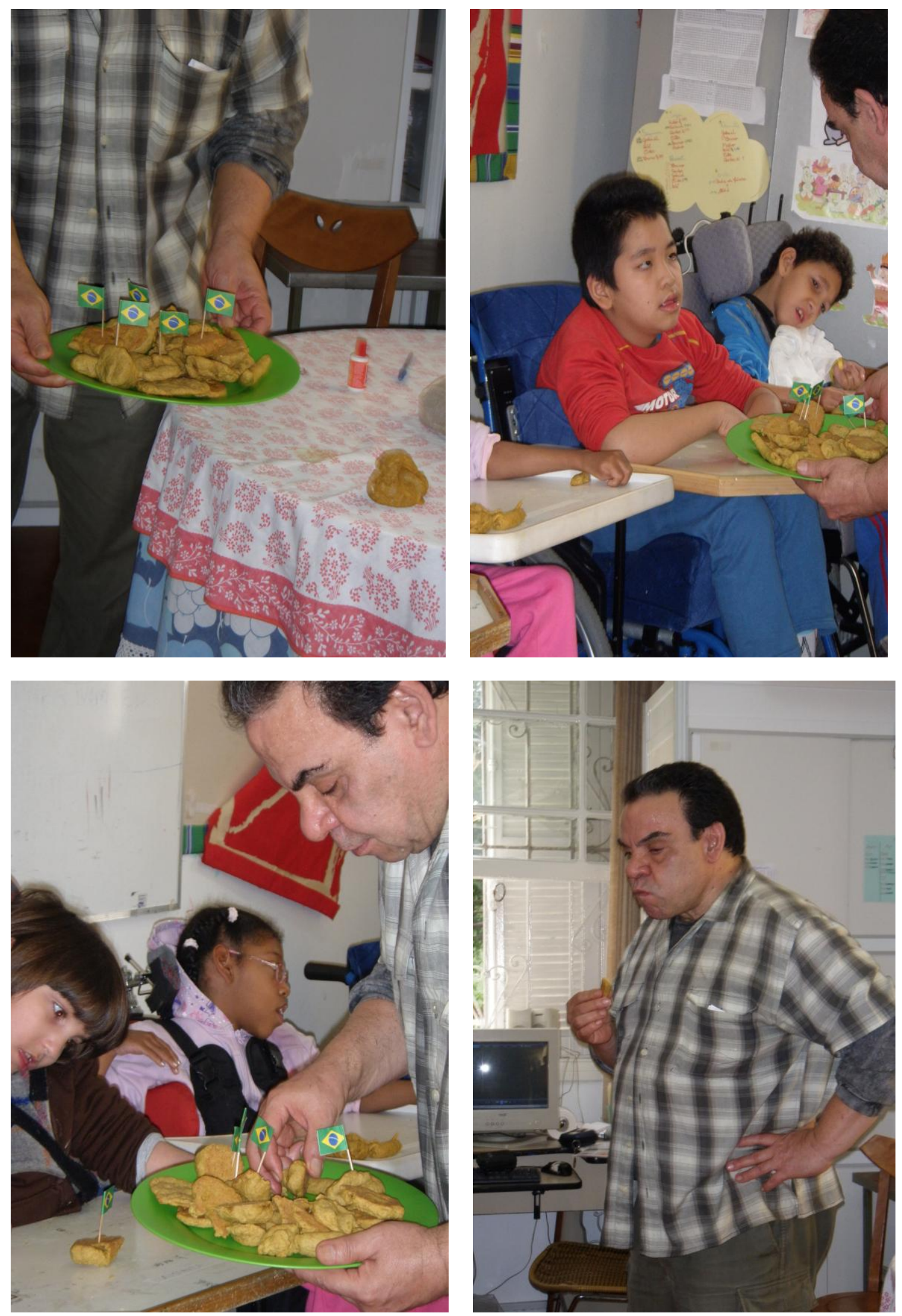
Em seguida eu montei um power point com as fotos da visita e da aula, pois acredito ser necessário estimular a memória após uma experiência completa e mostramos a eles demoradamente, sem pressa para saborearem cada momento que ficou gravado.

Depois fizemos pequenas esculturas em chocolate e vimos as obras de Vik Muniz.

Por fim fizemos uma escultura figurativa com a ajuda do nosso amigo ator, cenógrafo e dramaturgo Adonay Donley.

A foto abaixo se vista de relance representa uma incoerência. Adonay que esta ajudando uma criança a fazer uma escultura parece estar aplicando uma injeção, a incoerência é que a criança parece muito feliz o que jamais aconteceria com nenhum dos meus alunos que tem seus corpos tão massacrado por tratamentos dolorosos que a simples visão de alguém vestido de branco os assusta ou os deixa inquietos.

As auxiliares de enfermagem que me acompanham até a escola não podem ir vestidas de branco para não deixá-los alarmados.
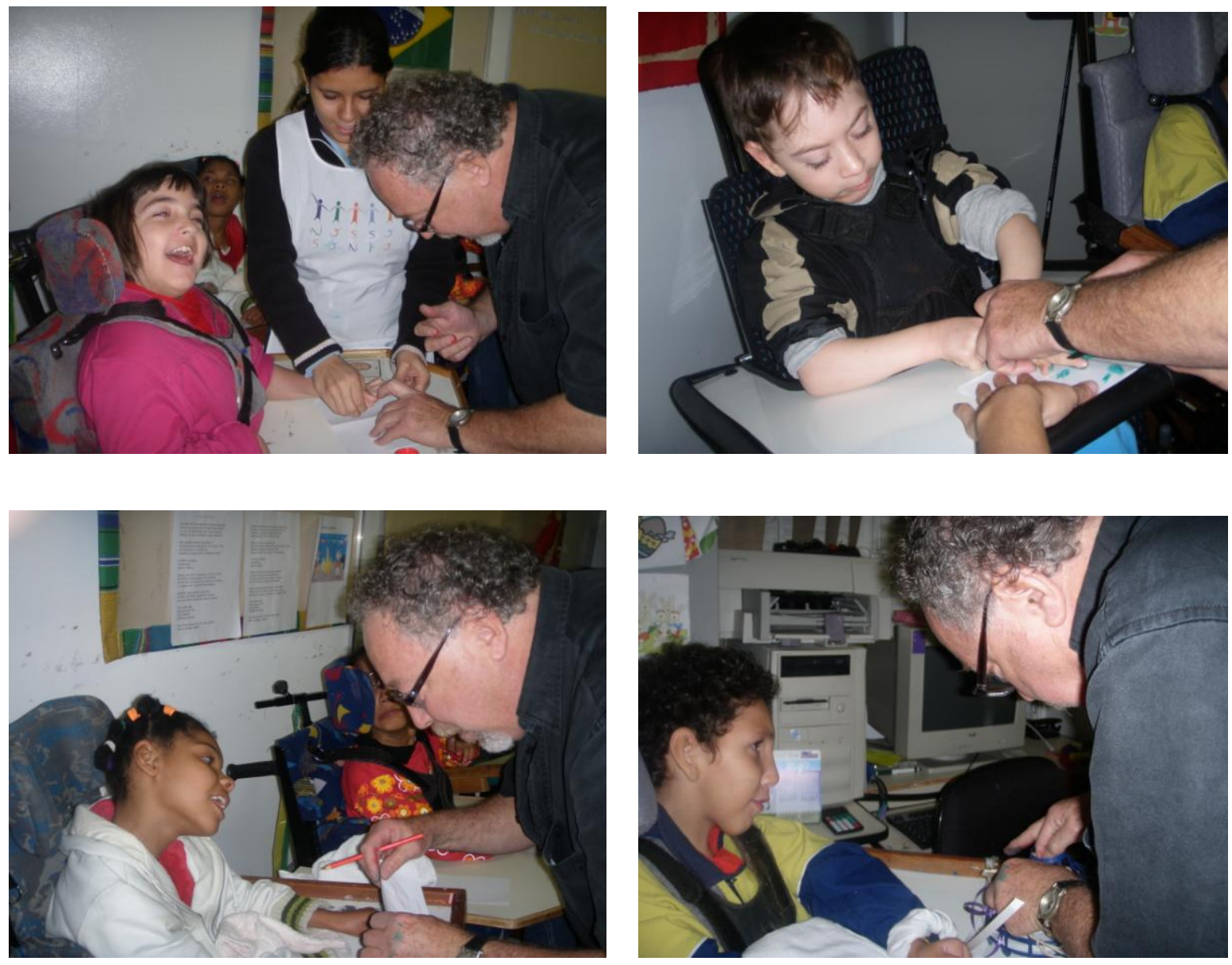

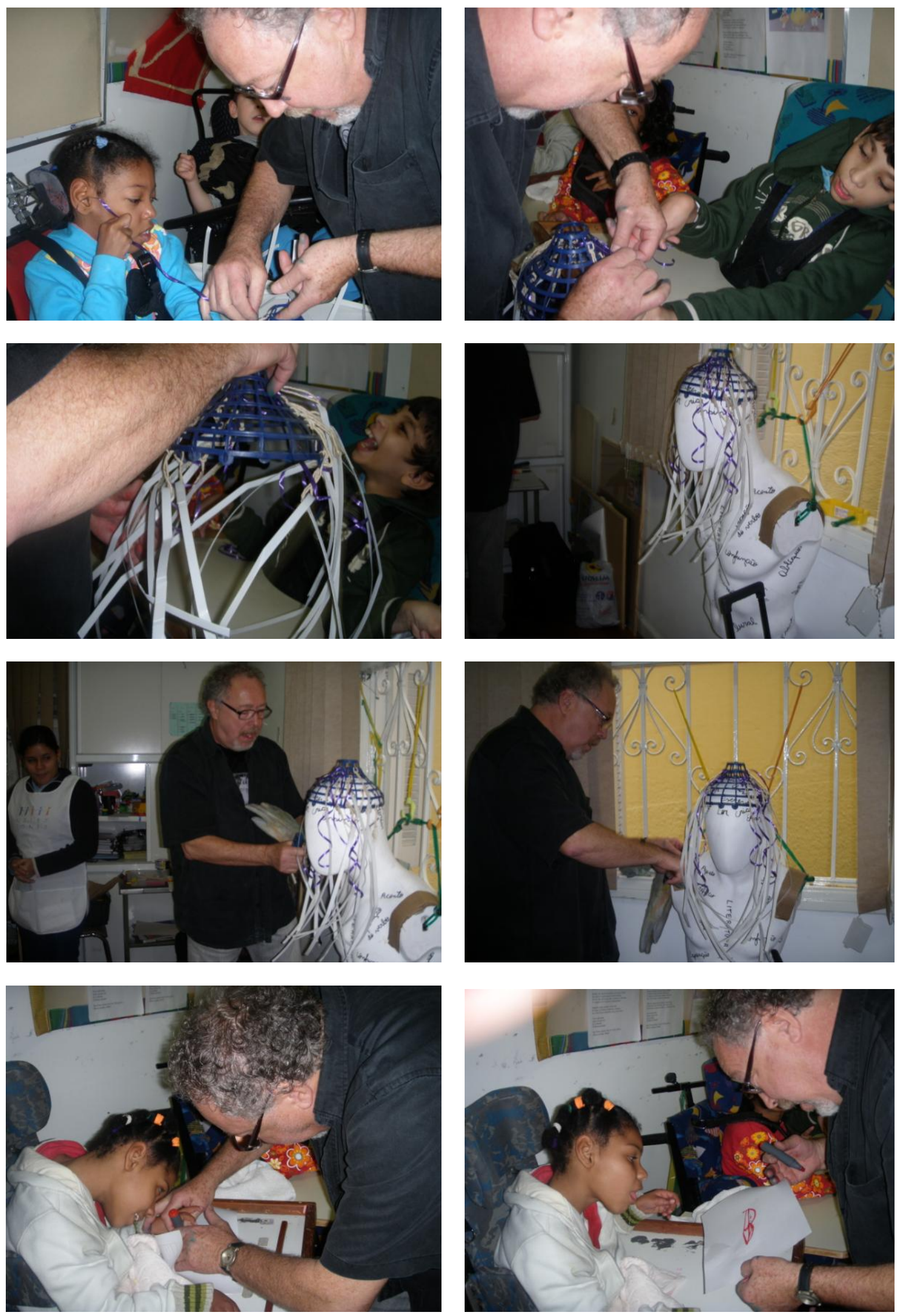

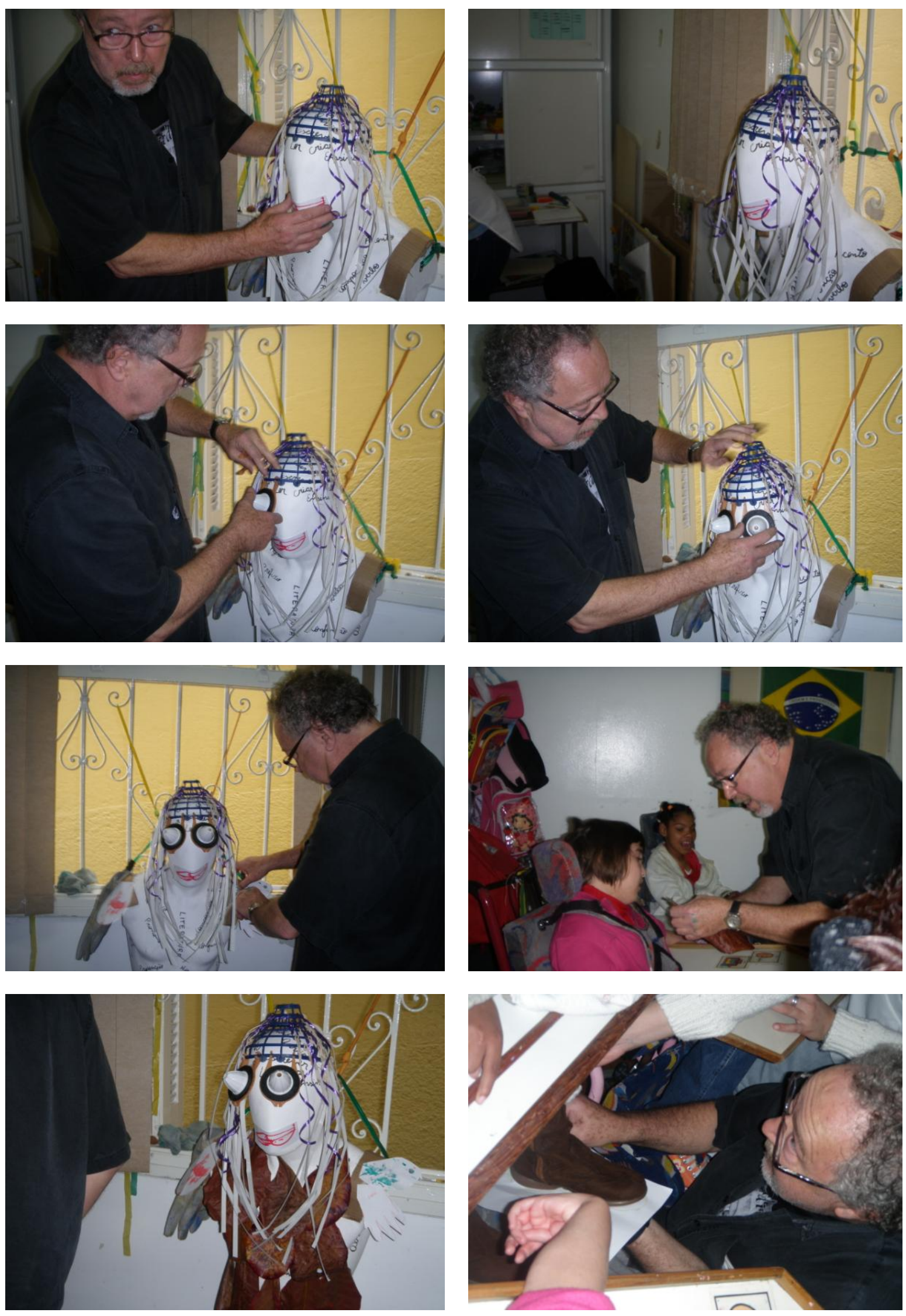

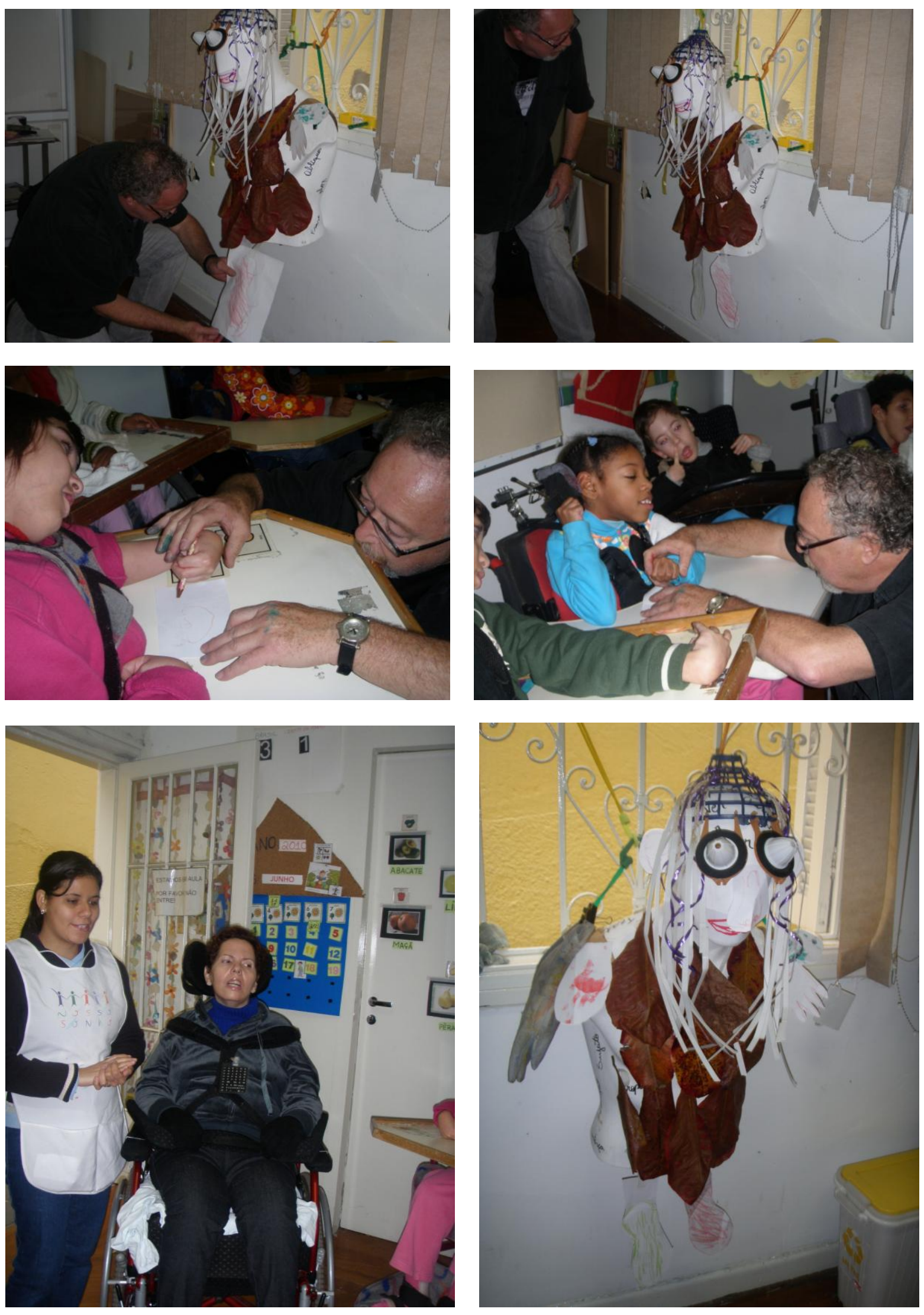
$28 / 06 / 2010$

FOTOS - PERDI AS FOTOS DO DIA 08/06 QUANDO EMBRULHAMOS AS IMPRESSÕES EM ARGILA NA NOSSO SONHO, E DO DIA 12/06 DA FESTA JUNINA DA LILIA, E DIA 15/06 QUANDO FIZEMOS AS ESCULTURAS DE CHOCOLATE NA NOSSO SONHO. (http://amaliabarbosa.zip.net)

Esta foi a minha maior frustração durante este projeto porque a felicidade estava estampada no rosto das crianças.

Retornamos às aulas em agosto.

$02 / 08 / 2010$

...AMANHÃ COMEÇAM AS AULAS NA NOSSO SONHO, EU AINDA NÃO VISUALIZEI O SEMESTRE, MAS SEI QUE TEM A BIENAL! (http://amaliabarbosa.zip.net)

OLÁ CRIANÇAS

COMO FORAM DE FERIAS? PASSEARAM? DESCANSARAM?

JÁ TAVA COM SAUDADES!

PREPARADOS PARA MAIS UM SEMESTRE?

HOJE VAMOS FAZER ALGO QUE JÁ FIZEMOS, MAS QUE NUNCA FICA IGUAL. EM UMA FOLHA A3, COLOQUE DUAS CORES, ESPALHE COM AS MÃOS, E DOBRE O PAPEL NO MEIO. O QUE ACONTECEU? 
Optei por relatar o segundo semestre de 2010 encadeando a aula com cartas roteiros, fotos e o que escrevia no blog.

Como tenho visão dupla, mais uma sequela do AVC, escrevo no blog e preparo as aulas em letras maiúsculas tamanho entre 18 a 22. Preferi manter o blog e as aulas exatamente como os escrevi.

OLÁ CRIANÇAS,

HOJE VAMOS USAR LÁPIS DE CERA E PAPEL A3. O TRABALHO PARECE FÁCIL, MAS REQUER MUITA ATENÇÃO DE VOCÊS:

TAMIRES E FABI VÃO COLOCAR VOCÊS EM RODA E VÃO COLOCAR UMA CADEIRA EM CIMA DE UMA MESA BEM NO MEIO DA RODA. OLHEM BEM A CADEIRA E QUANDO ESTIVEREM PRONTOS, DESENHEM A CADEIRA, ELA NÃO TEM QUE FICAR IGUAL. FAÇAM PELO MENOS 2 DESENHOS E AO TERMINAR VAMOS BATER UMA FOTO DE COMO VOCÊ VIU A CADEIRA E OUTRA DOS SEUS DESENHOS.

INFELIZMENTE EU NÃO VENHO TERÇA QUE VEM (DIA 17) PORQUE TENHO MEDICO E NÃO CONSEGUI MUDAR O HORÁRIO

ANA AMÁLIA

$10 / 08 / 2010$ 

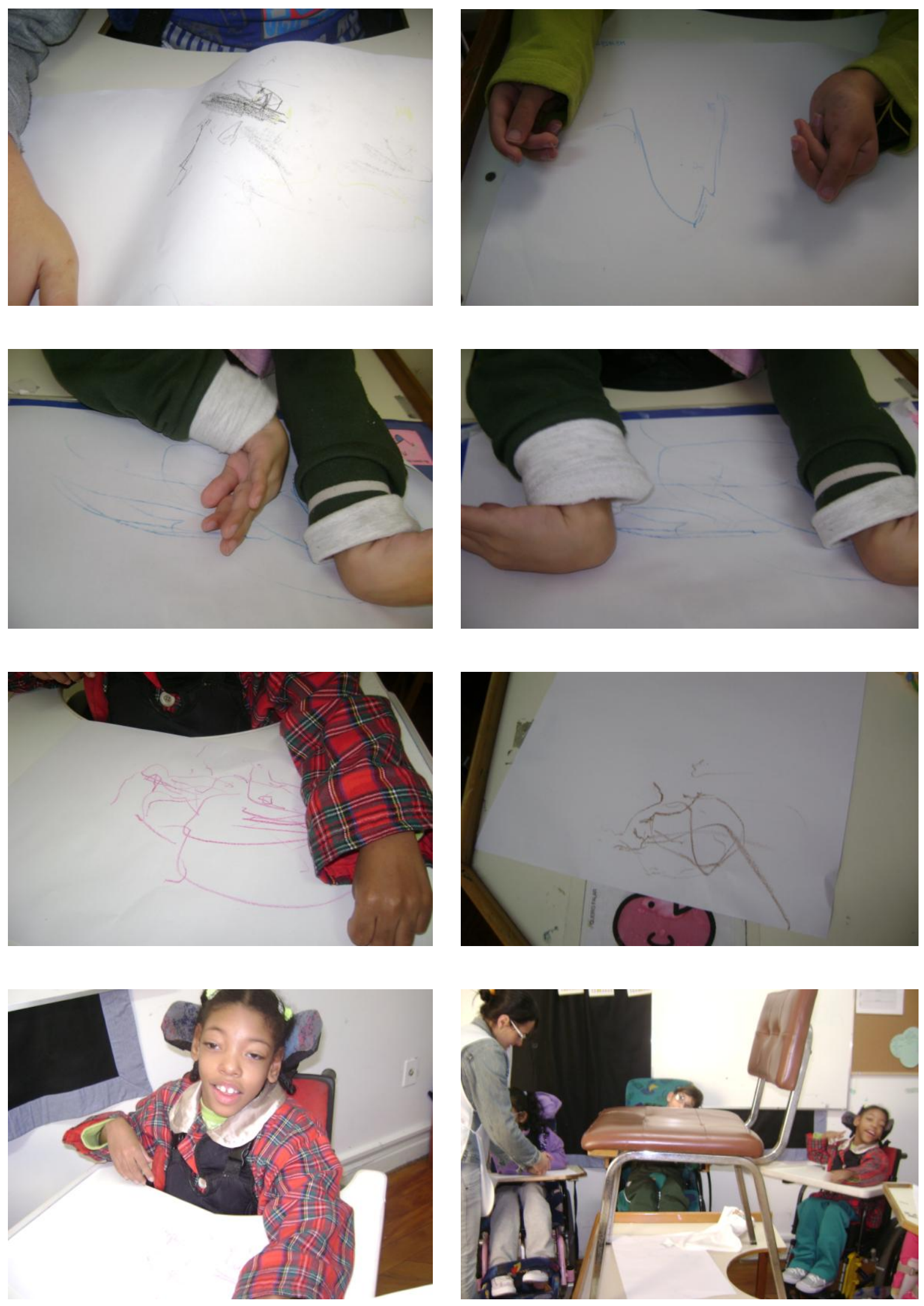

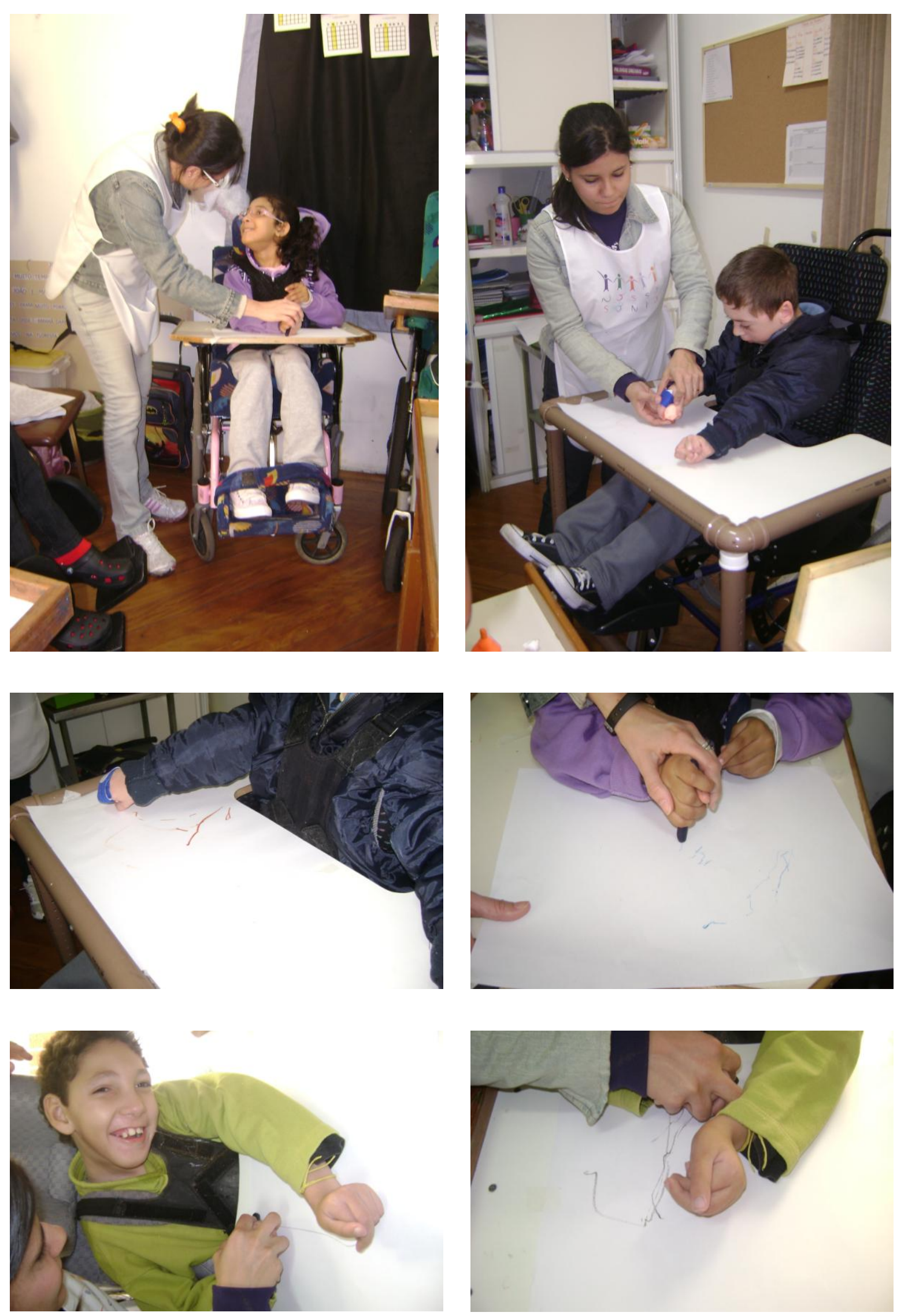

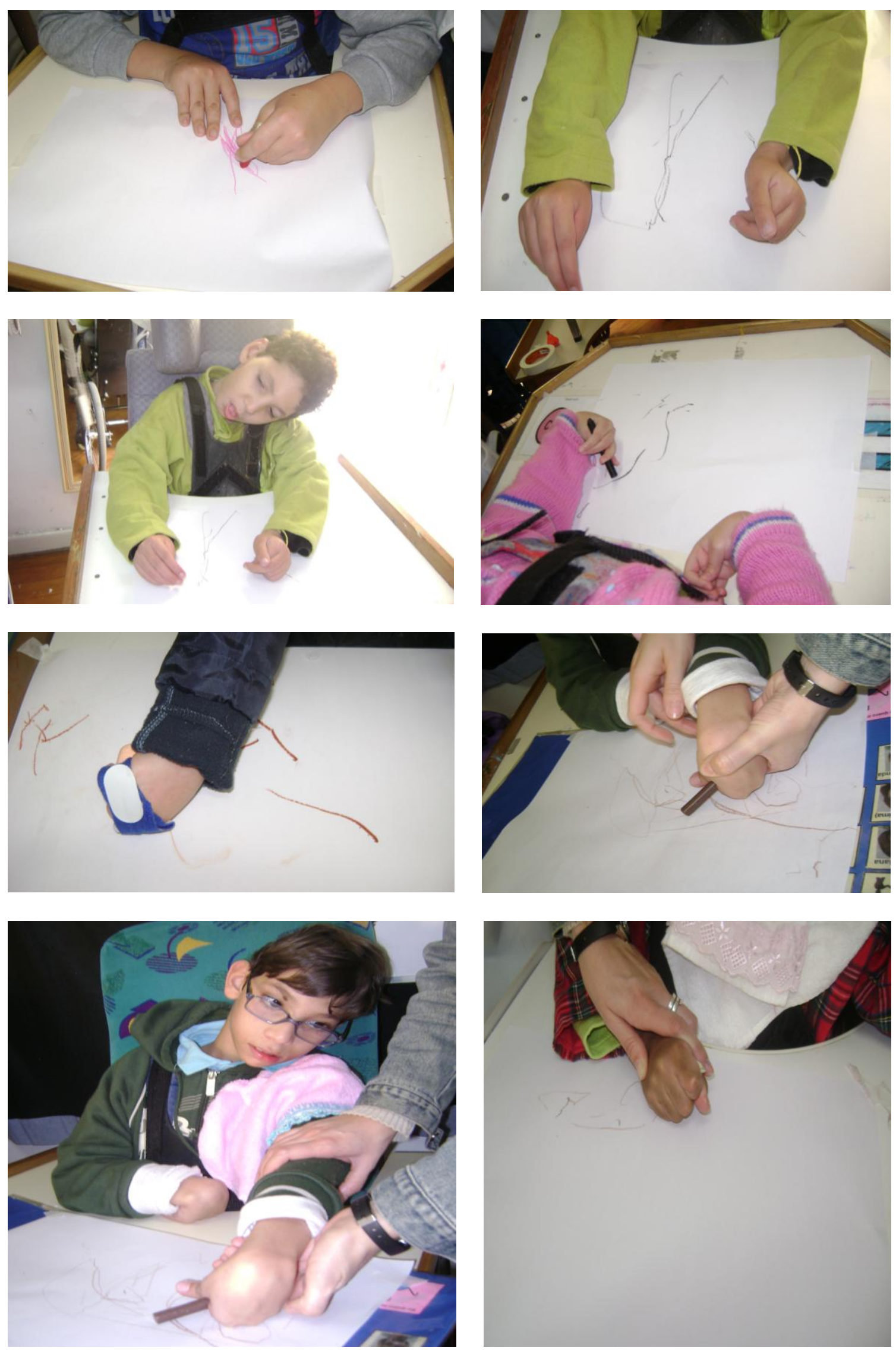

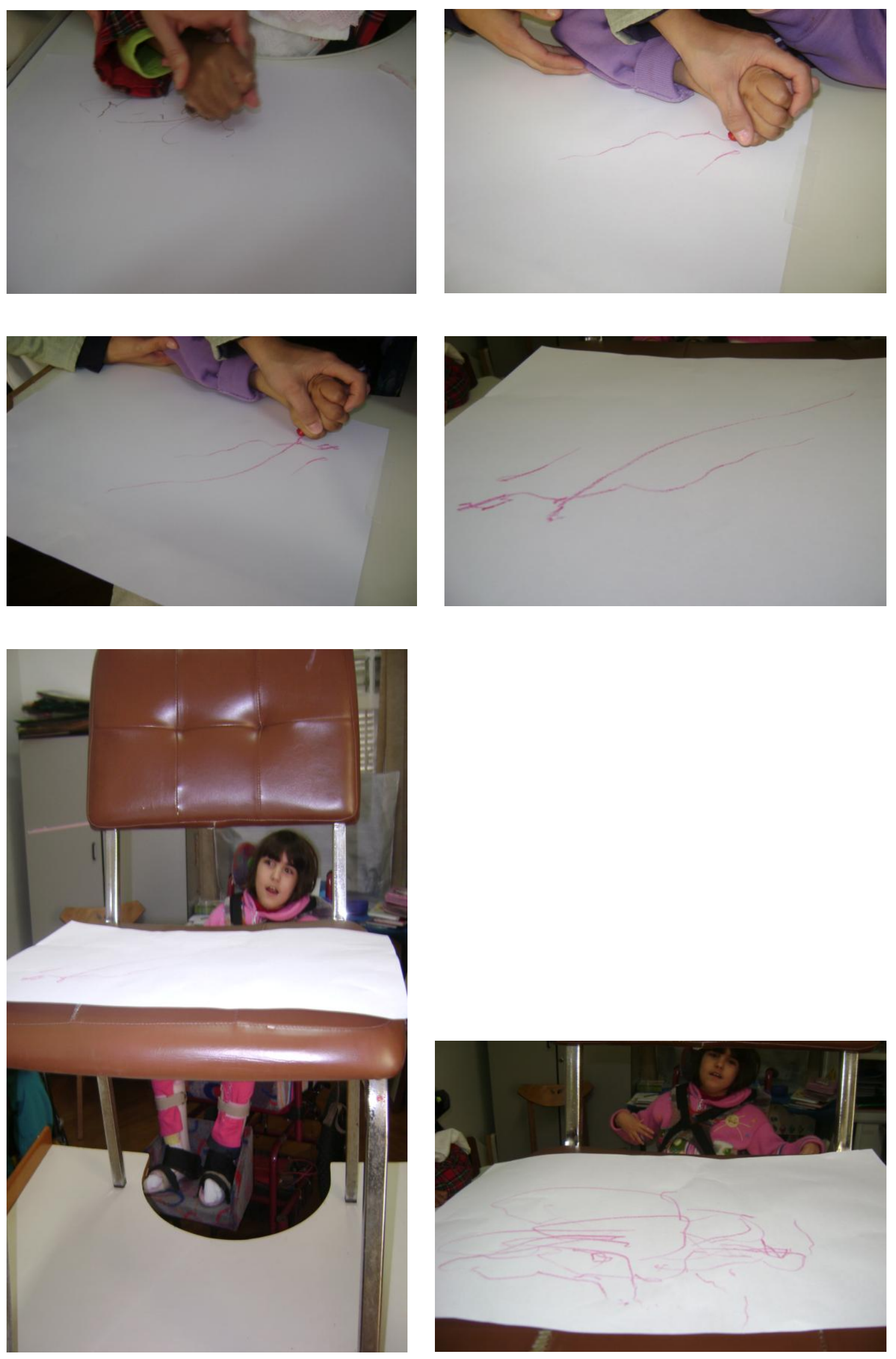

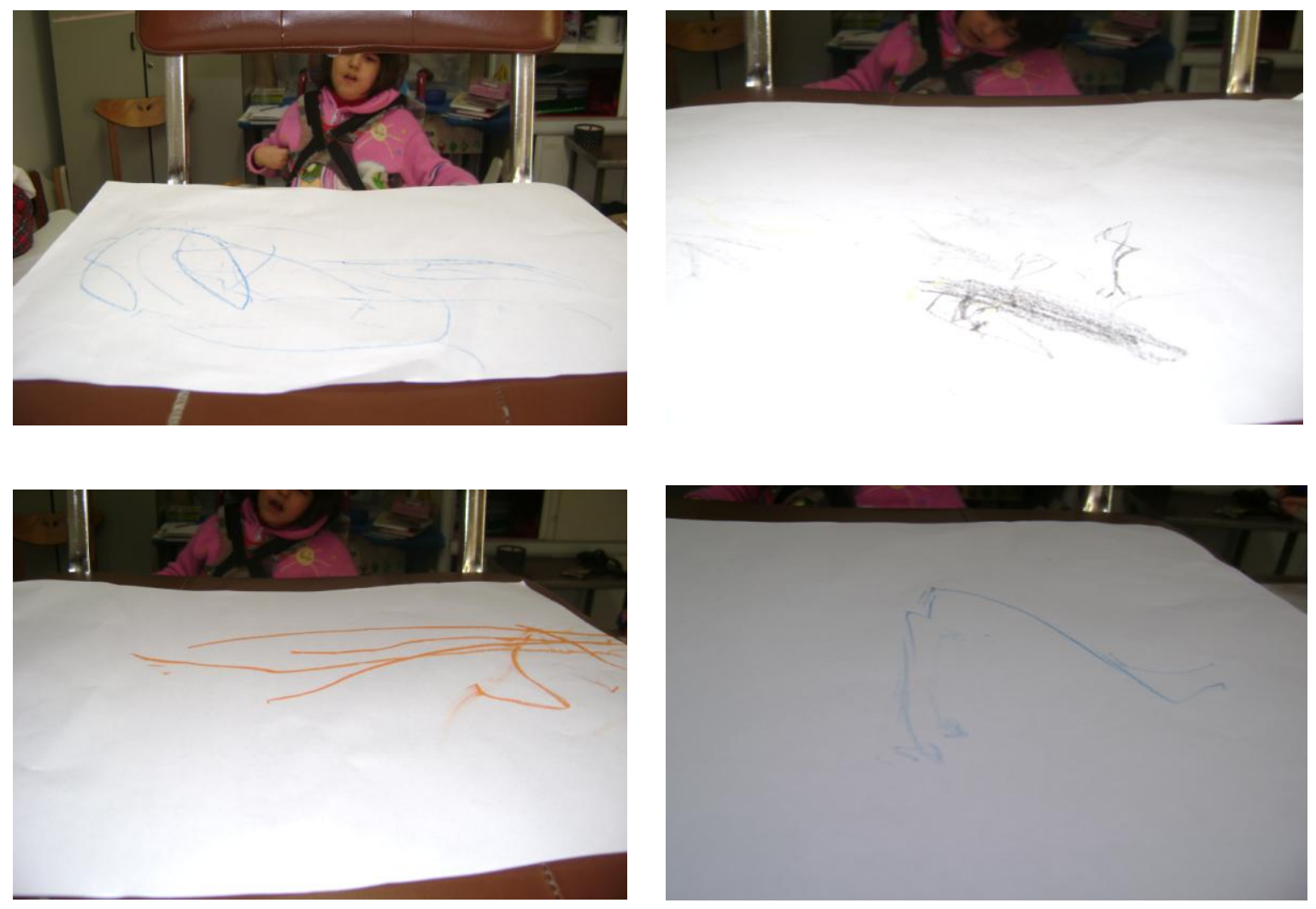

OLÁ CRIANÇAS,

VAMOS CONTINUAR COM DESENHO DE OBSERVAÇÃO, MAS HOJE NÃO QUERO QUE USEM APENAS A VISÃO. UM PREGADOR DE ROUPA VAI SER COLOCADO NA SUA MÃO, SINTA A FORMA, O MATERIAL E DESENHE.

FAÇA 3 DESENHOS, NO MESMO PAPEL E MUDANDO DE COR DE GIZ A CADA DESENHO.

NA AULA QUE VEM EU MOSTRO PORQUE O PREGADOR DE ROUPA.

ANA AMÁLIA 
OLAH CRIANÇAS

NA AULA PASSADA EU PEDI PRA VCS DESENHAREM UM PREGADOR DE ROUPAS.

HOJE VAMOS VER AS OBRAS DE (CLAUS OLDEMBERG) CLAES OLDEMBURG, UM ARTISTA SUECO, NASCIDO EM 1929, QUE MORA E TRABALHA NOS ESTADOS UNIDOS. ELE FAZ ESCULTURAS ENORMES DE COISAS COTIDIANAS, COMO UMA COLHER OU UM PREGADOR DE ROUPAS. FAZ COM QUE A GENTE PARE E PRESTE ATENÇÃO ÀS COISAS DO DIA A DIA.

ANA AMÁLIA

$31 / 08 / 2010$

Claes Oldenburg
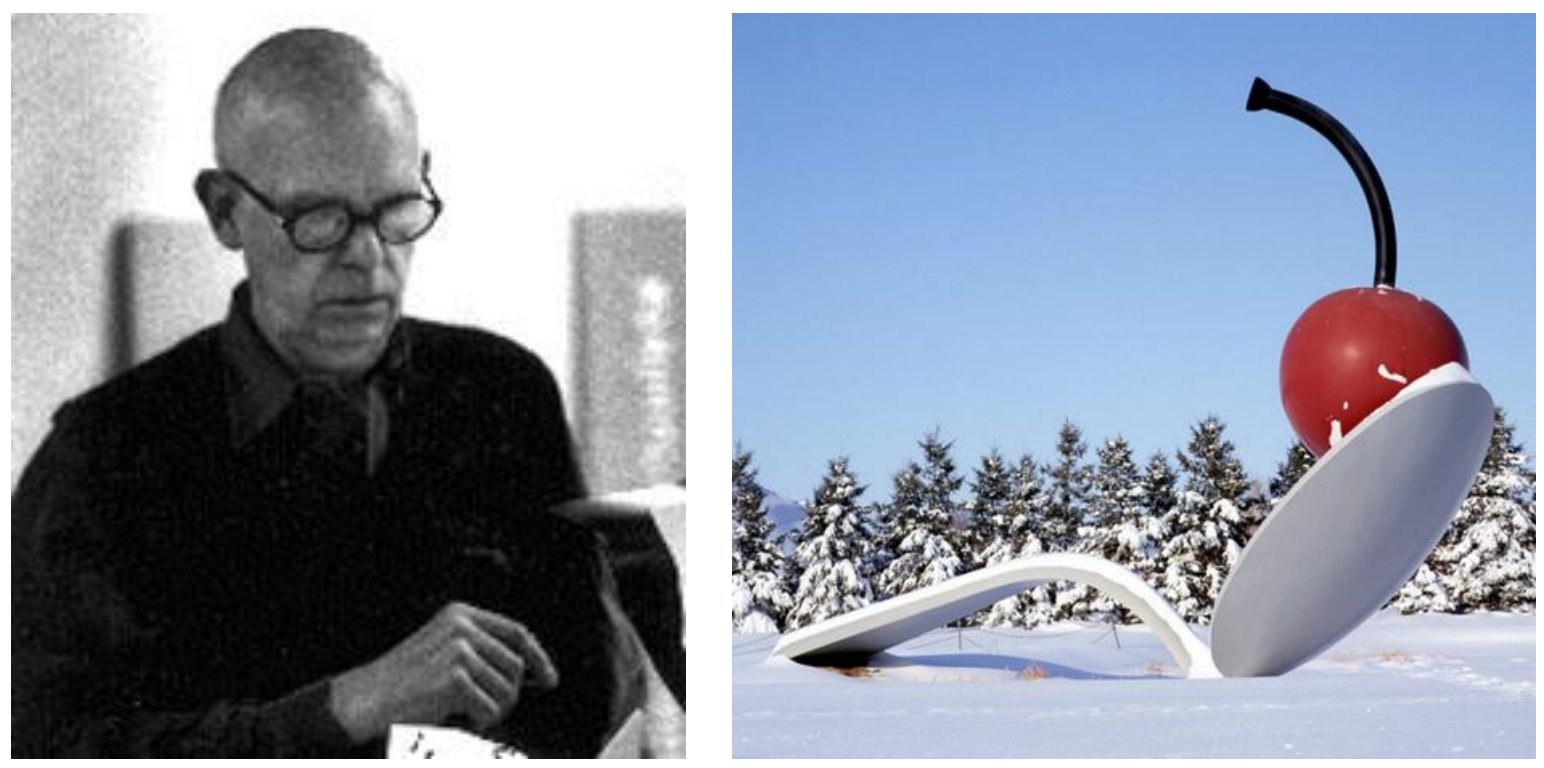

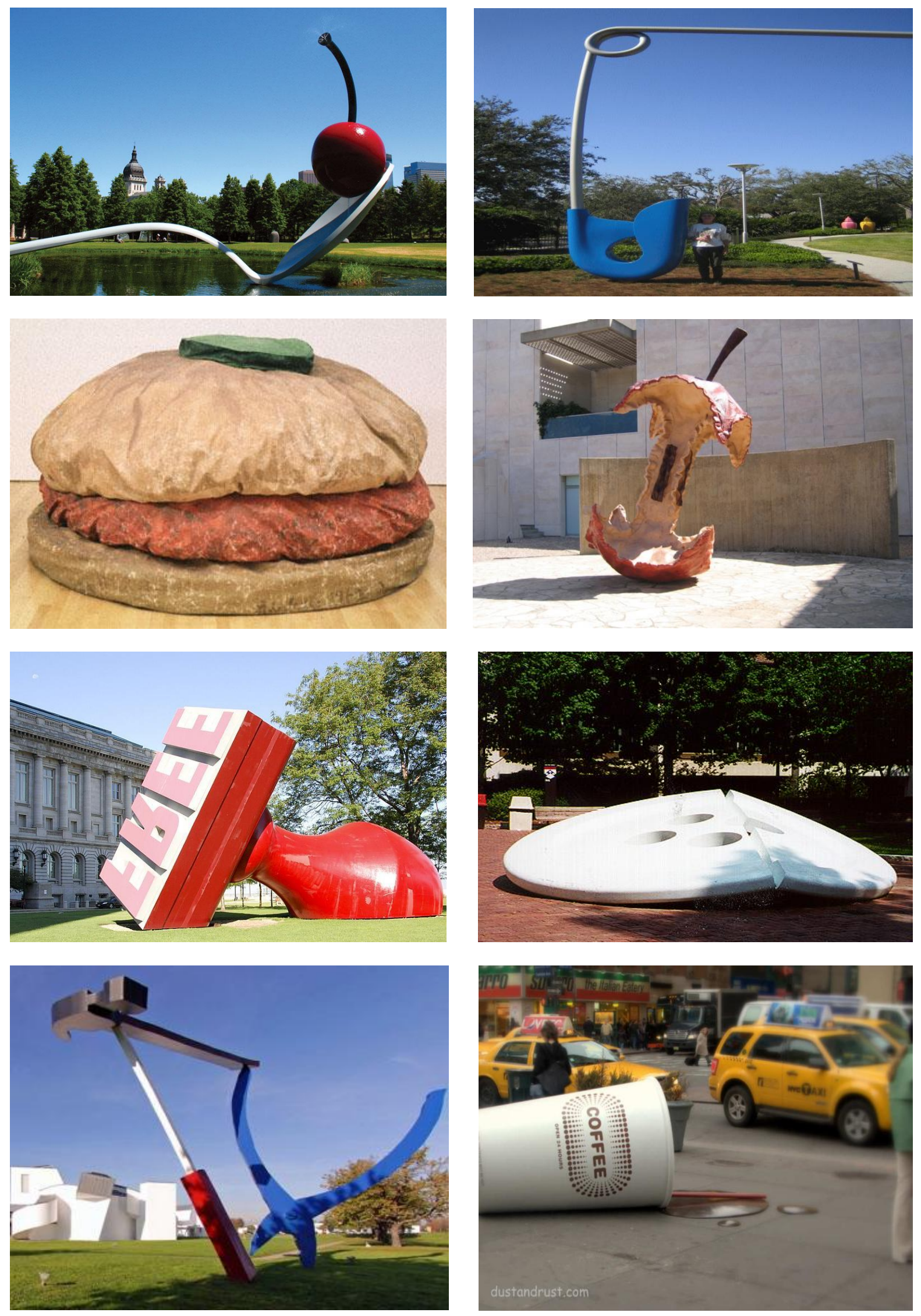

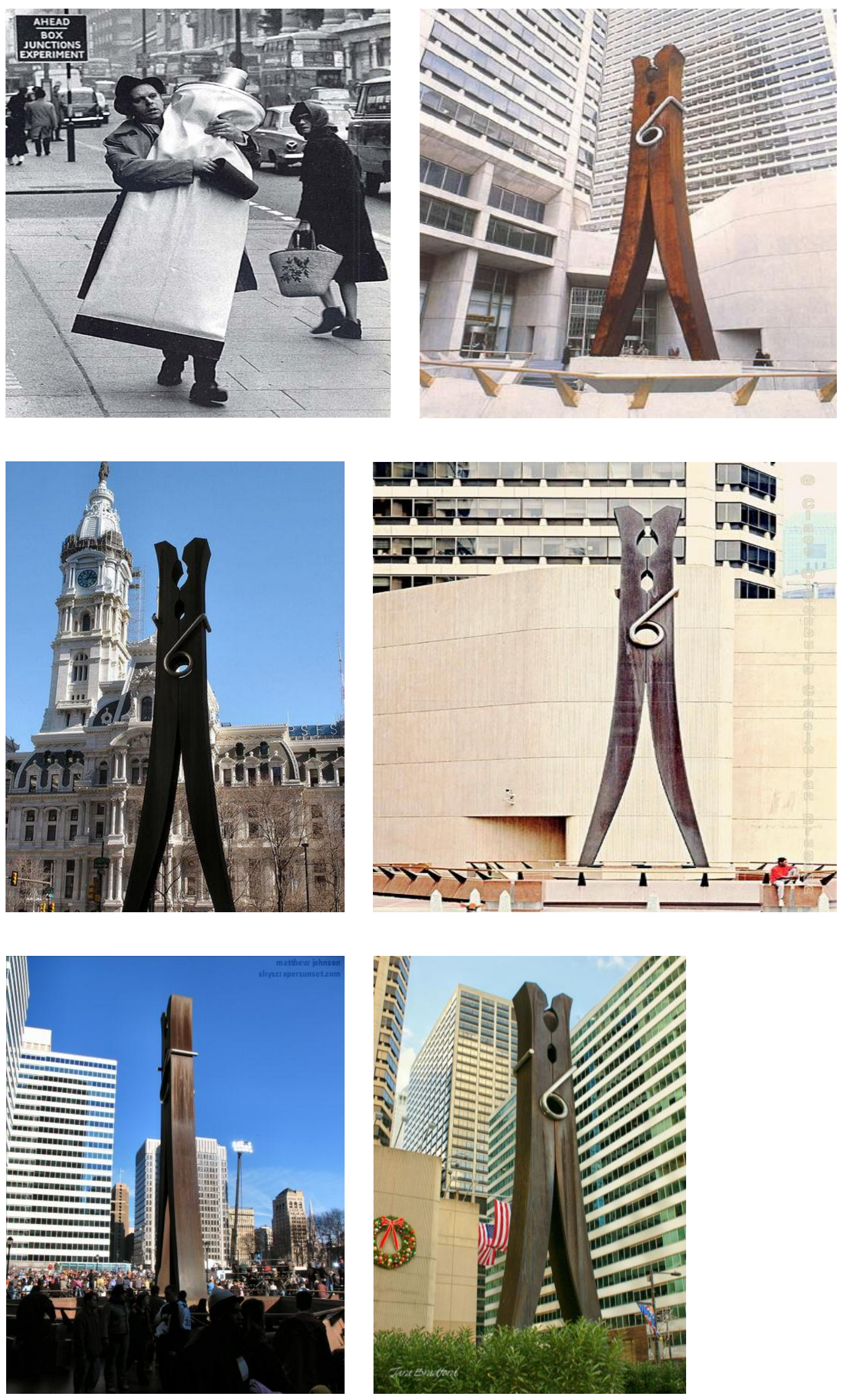


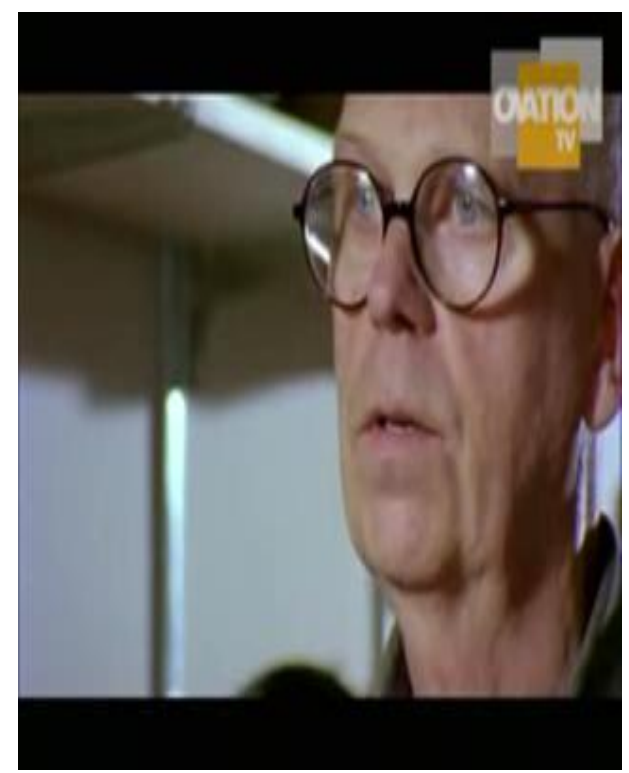

OLÁ CRIANÇAS,

HOJE VAMOS LIGAR OS SENTIMENTOS ÀS CORES. VOU DIZER UM SENTIMENTO E QUERO QUE VOCÊS ESCOLHAM UMA COR PARA REPRESENTAR ESSE SENTIMENTO, DEPOIS FAÇAM UMA MANCHA COM UMA MÃO. MAIS UM SENTIMENTO, MAIS UMA MANCHA AO LADO.

1. ALEGRIA

2. TRISTEZA

3. FELICIDADE

4. RAIVA

(TAMIRES, FALA UM SENTIMENTO, FAZ A MANCHA E SÓ FALA O PRÓXIMO SENTIMENTO QUANDO TODOS FIZEREM A MANCHA ANTERIOR E EH TUDO EM UMA FOLHA SÓ)

SEMANA QUE VEM EU TENHO MEDICO DE NOVO, INFELIZMENTE EU NÃO VENHO. ANA AMÁLIA 21/09/2010 


\section{OLÁ CRIANÇAS}

HOJE VAMOS VER ALGUMAS PINTURAS NO COMPUTADOR E QUINTA-FEIRA VAMOS PASSEAR DE TREM E FAZER UM PIQUENIQUE NO PARQUE. DURANTE NOSSO PASSEIO LEMBREM-SE DAS PINTURAS QUE VOCÊS VIRAM.

$$
\begin{array}{r}
\text { ANA AMÁLIA } \\
05 / 10 / 2010
\end{array}
$$

NO DIA 07/10/2010 FOMOS A ESTAÇÃO DA LUZ DE TREM.
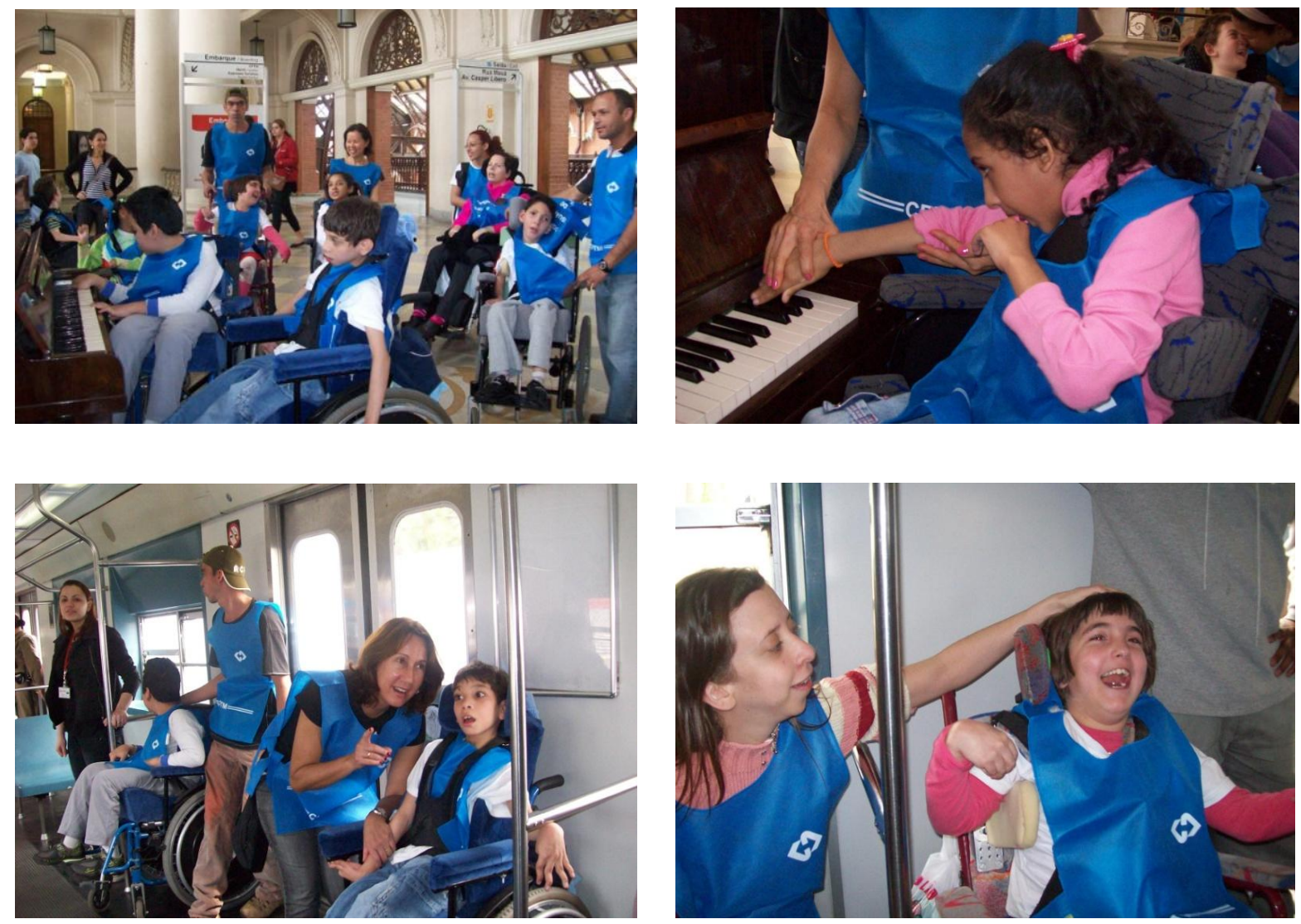

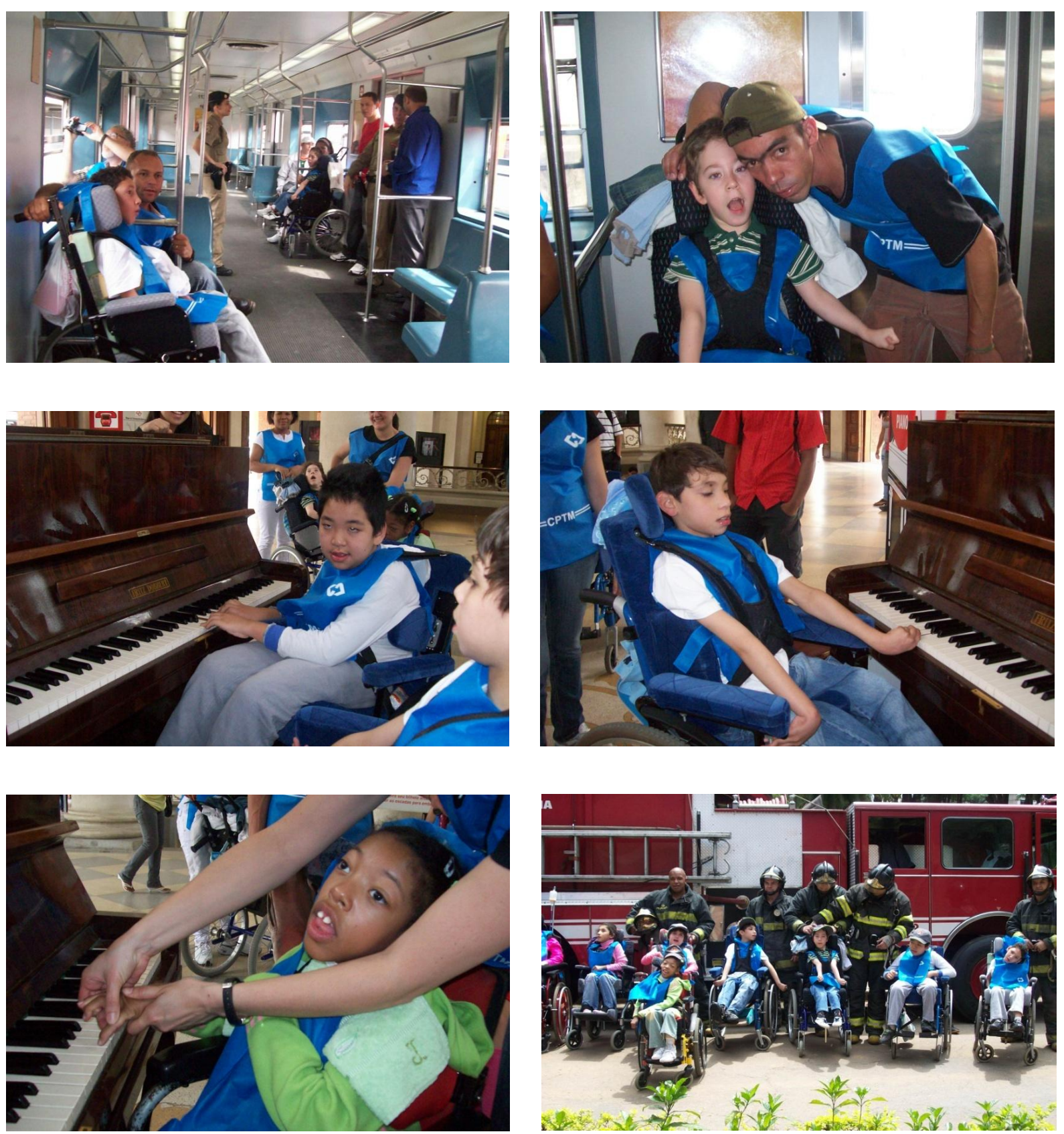

OLÁ CRIANÇAS

HOJE A AULA VAI TER DUAS PARTES.

PRIMEIRO VAMOS USAR O COMPUTADOR E REVER A ESTAÇÃO DE TREM PINTADA POR CLAUDE MONET. ELA É PARECIDA COM A ESTAÇÃO DA LUZ? ELAS FORAM CONSTRUÍ- 
DAS NA MESMA ÉPOCA A ESTAÇÃO DA LUZ VEIO DESMONTADA DA EUROPA E A DO MONET EH NA EUROPA.

DEPOIS EU VOU DISTRIBUIR ALGUMAS FOTOS DA ESTAÇÃO DA LUZ, ESCOLHAM AS CORES QUE REPRESENTAM SEUS SENTIMENTOS NA NOSSA VISITA E PINTEM AS FOTOS USANDO OS PINCEIS.

ANA AMÁLIA

$19 / 10 / 2010$

OLÁ CRIANÇAS

USANDO A PONTA DOS DEDOS, PINTEM UMA FOLHA A3. ESCOLHAM TRÊS CORES QUE VOCÊ ACHEM ALEGRES E PENSE COMO ESSAS CORES VÃO ESTAR ORGANIZADAS NO PAPEL.

USEM SÓ A PONTA DOS DEDOS, FAZENDO PEQUENOS PONTOS.

SE DER TEMPO FAÇAM MAIS UM COM CORES TRISTES.

ANA AMÁLIA

$26 / 10 / 2010$
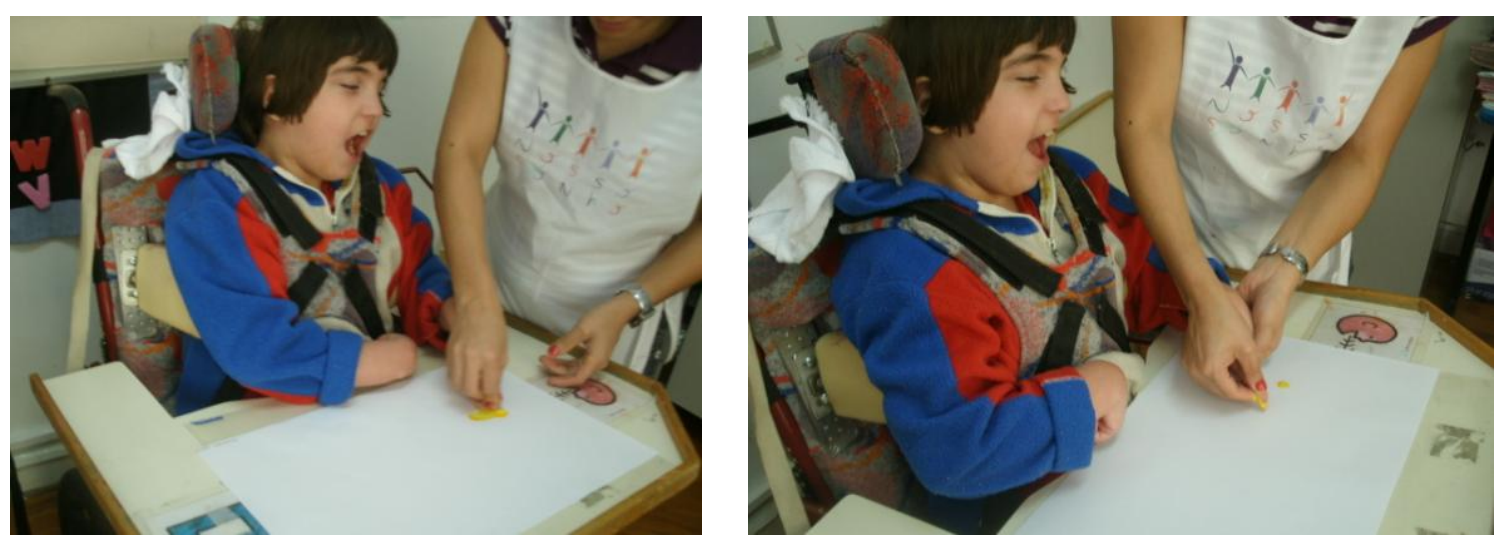

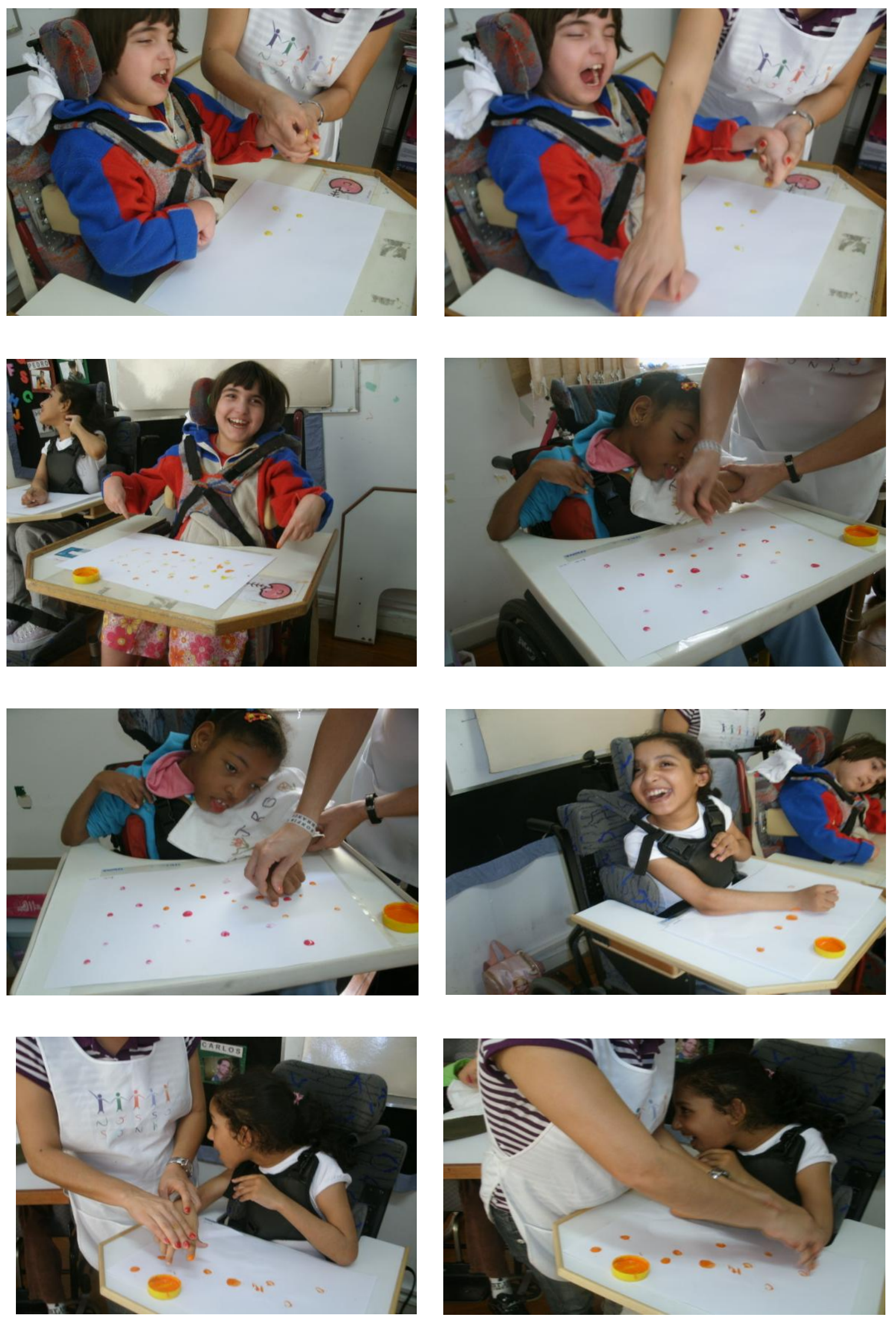

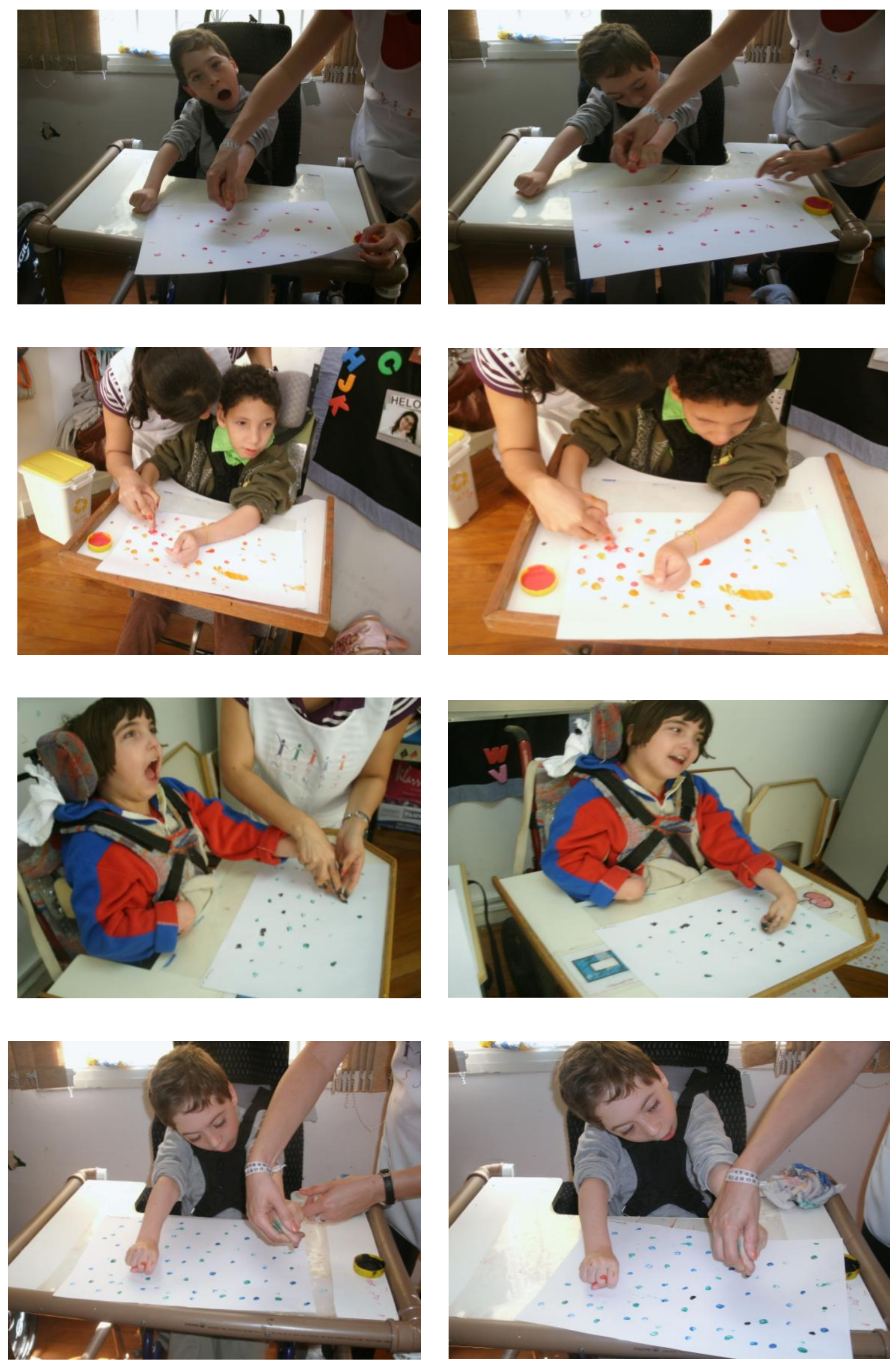

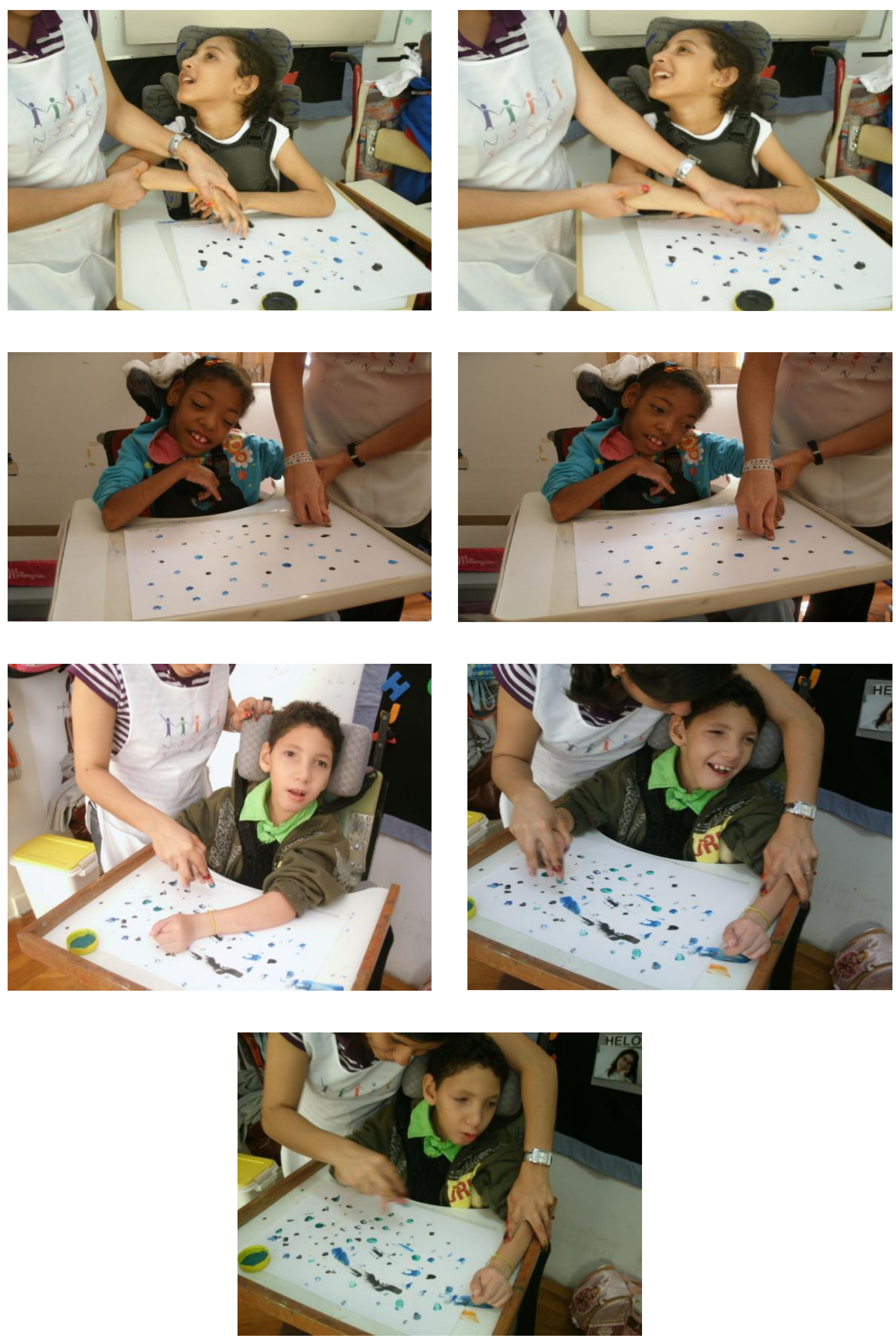
A preocupação em leva-los ao controle do traçado das linhas e o fechamento de linhas no espaço que vem foi sendo gradativamente introduzido desde a visita ao Instituto Tomie Ohtake encontrou eco nas experiências de Maria Lucia Batezart Duarte com crianças invisuais e especialmente com a aluna Manuela com quem a autora fez uma pesquisa longitudinal.

Segundo Batezart (2011, p. 125) deve-se conduzir

as crianças invisuais a realizarem o fechamento de linhas no espaço. Este acontecimento leva ao desenho das primeiras figuras, que passam a ser identificadas (por analogia morfológica) e nomeadas.Todo esse processo é de natureza basicamente visual. Por isso, com crianças invisuais é necessário iniciar a construção de toda uma significação do ato de desenhar, as razões para desenhar linhas, planos e figuras. É preciso, primeiro,encontrar as linhas de contorno na bordas de superfície dos objetos e brinquedos. Começa então, um trabalho semelhante aquele realizado pelos professores como preparatório á alfabetização e a escrita. É necessário vivenciar com a criança invisual.:

O traçado de linhas retas e curvas em diferentes direções e dimensões.

O traçado de linhas em movimento (ondulares, côncavos e convexos, em ziguezague etc:

Apresentar e desenhar as figuras geométricas básicas: o círculo, o quadrado e o triângulo."

Tenho quatro alunos com déficit visual e um com déficit de atenção visual resultado de tomar fortes remédios contra dor constantemente. A ideia de trabalhar com linhas fechadas em molde vasados deu excelentes resultados porque já induzia ao fechamento da linha ou do espaço. Usar diretamente as mãos também facilitou pelo uso da ação sensorial direta.

OLÁ CRIANÇAS, PEGUEM A PINTURA DA AULA PASSADA. COLOQUEM UM MOLDE VAZADO DE UMA FORMA ORGÂNICA EM CIMA DA SUA PINTURA, ESCOLHAM UMA COR E PINTEM USANDO APENAS OS DEDOS. COLOQUE OUTRO MOLDE VAZADO DE UMA FORMA ORGÂNICA LIGEIRAMENTE EM CIMA DO OUTRO, ESCOLHA 
OUTRA COR E PINTE NOVAMENTE USANDO APENAS OS DEDOS.

ANA AMÁLIA $09 / 11 / 2010$
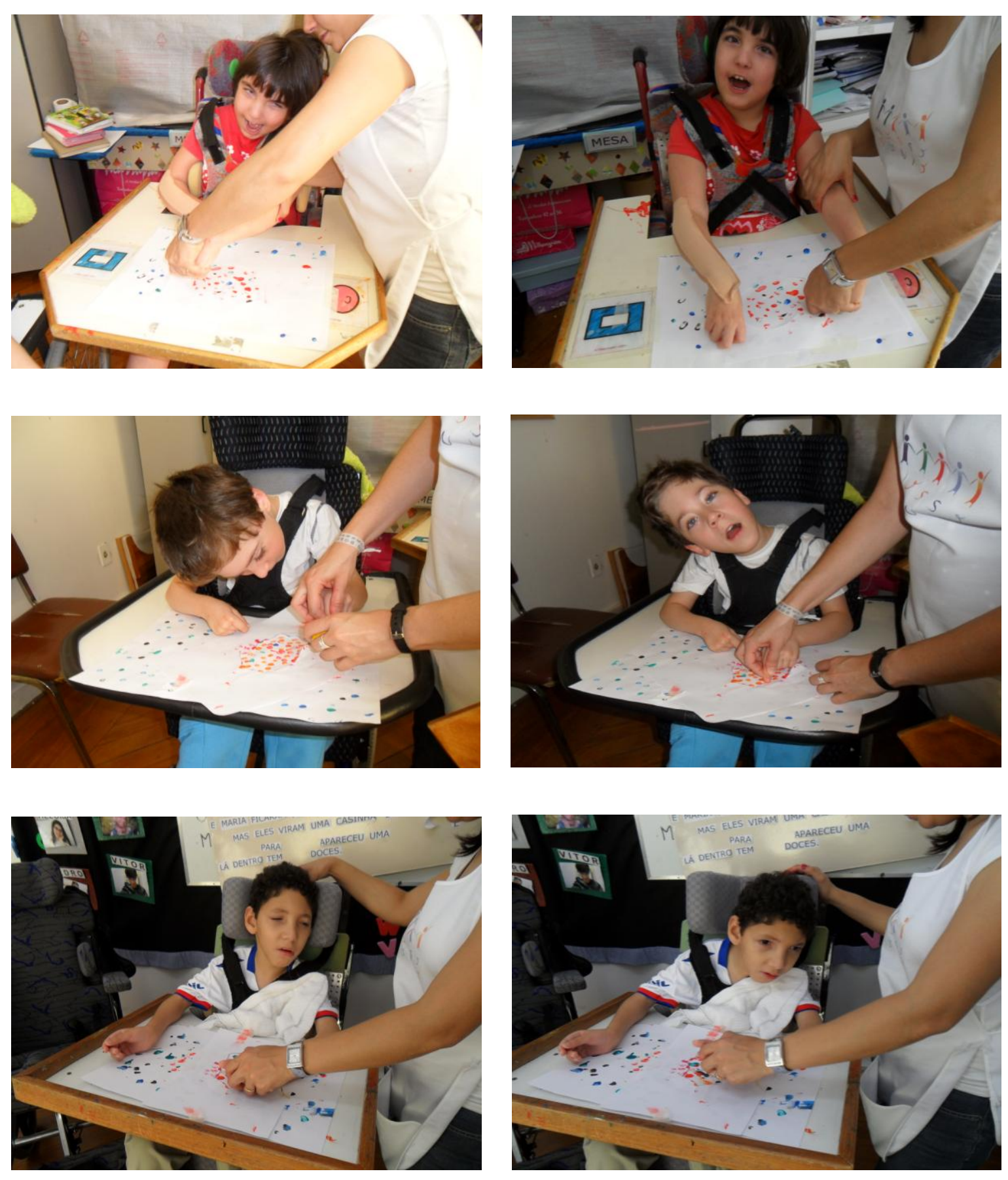

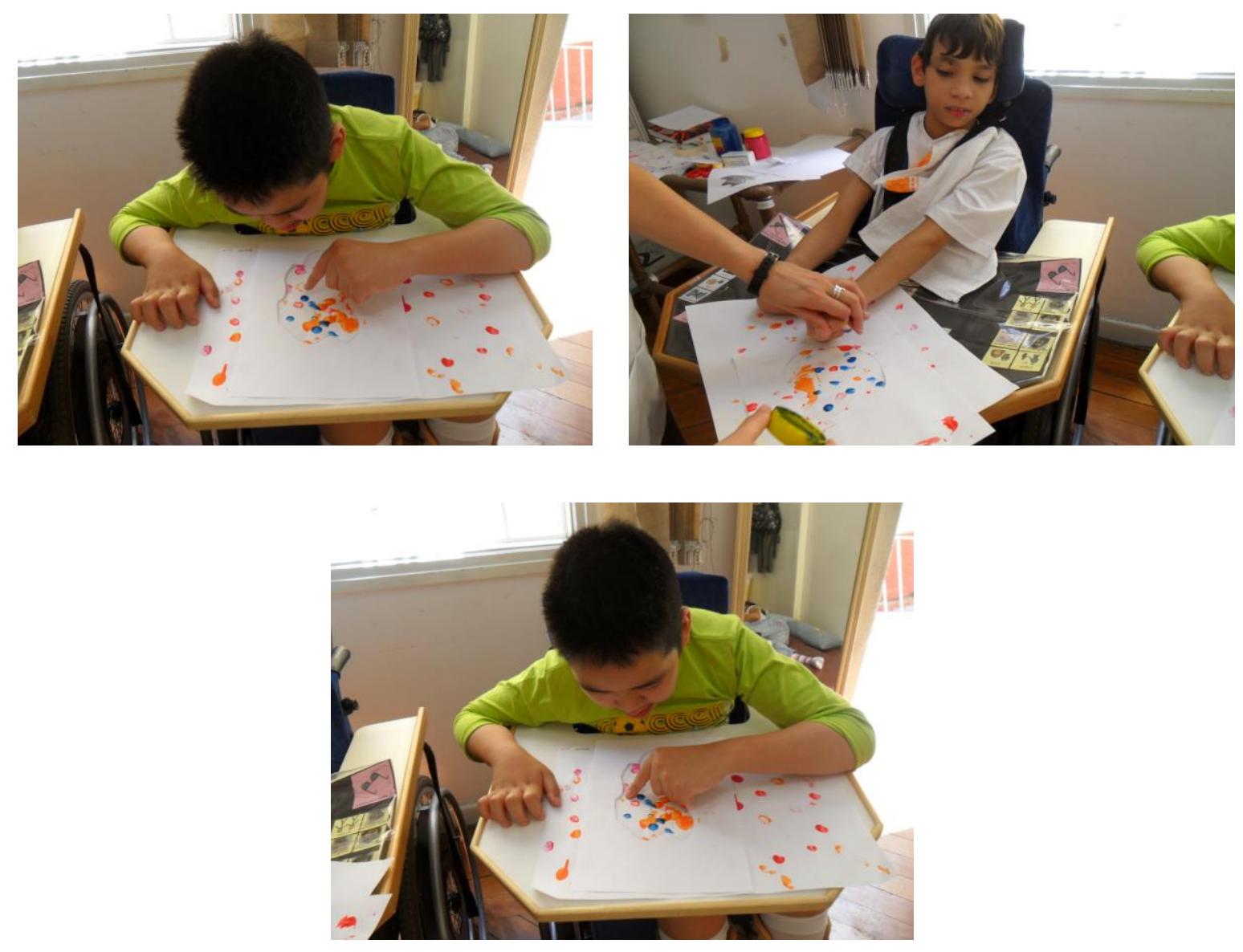

$23 / 11 / 2010$

HOJE NÃO TEVE AULA PQ AS CRIANÇAS FORAM NO PLAYCENTER. (http://amaliabarbosa.zip.net)

$29 / 11 / 2010$

SABADO FOMOS AO MAM. EU HAVIA PEDIDO AO NETO QUE AGENDASSE COM O SERVIÇO EDUCATIVO PARA QUE ATENDESSEM MEUS ALUNOS. PENA QUE SOH UMA ALUNA APARECEU, MAS TUDO BEM! PQ A RELAÇÃO DELA COM A OBRA DE ERNESTO NETO PÔDE SER ITENSIFICADA. LINDO!! 
DOMINGO TEVE BAZAR NA NOSSO SONHO. (http://amaliabarbosa.zip.net)

\section{OLÁ CRIANÇAS}

QUANTO TEMPO! EU FALTEI, VOCÊS FORAM NO PLAYCENTER, MAS NO SÁBADO EU VI A AMANDA QUE FOI AO MUSEU DE ARTE MODERNA NA EXPOSIÇÃO DE ERNESTO NETO. PENA QUE NÃO DEU PRA VOCÊS IREM.

HOJE VAMOS CONTINUAR COM PONTILHISMO, SÓ QUE EM UM PAPEL A4 QUE É METADE DO PAPEL QUE COSTUMAMOS USAR.

PRIMEIRO TAMIRES E FABIANA VÃO FAZER 2 MOLDES VAZADOS DA FLOR MARGARIDA DE TAMANHOS DIFERENTES.

COLOQUEM UM MOLDE SOBRE O PAPEL, ESCOLHAM UMA COR E COM A PONTA DOS DEDOS, PINTE A MARGARIDA SEM DEIXAR NEM UM BRANQUINHO DO PAPEL APARECER. REPITA O PROCESSO COM O OUTRO MOLDE.

PARE!

OLHE SEU DESENHO E DECIDA QUANTAS MARGARIDAS VAI COLOCAR, E DE QUE TAMANHO ELAS VÃO SER, ALEM DA COR E DA POSIÇÃO.

UFA! QUANTA DECISÃO! 
MAS AINDA NÃO ACABOU, SÓ QUE VAI FICAR PARA A AULA QUE VEM.

ANA AMÁLIA $30 / 11 / 2010$
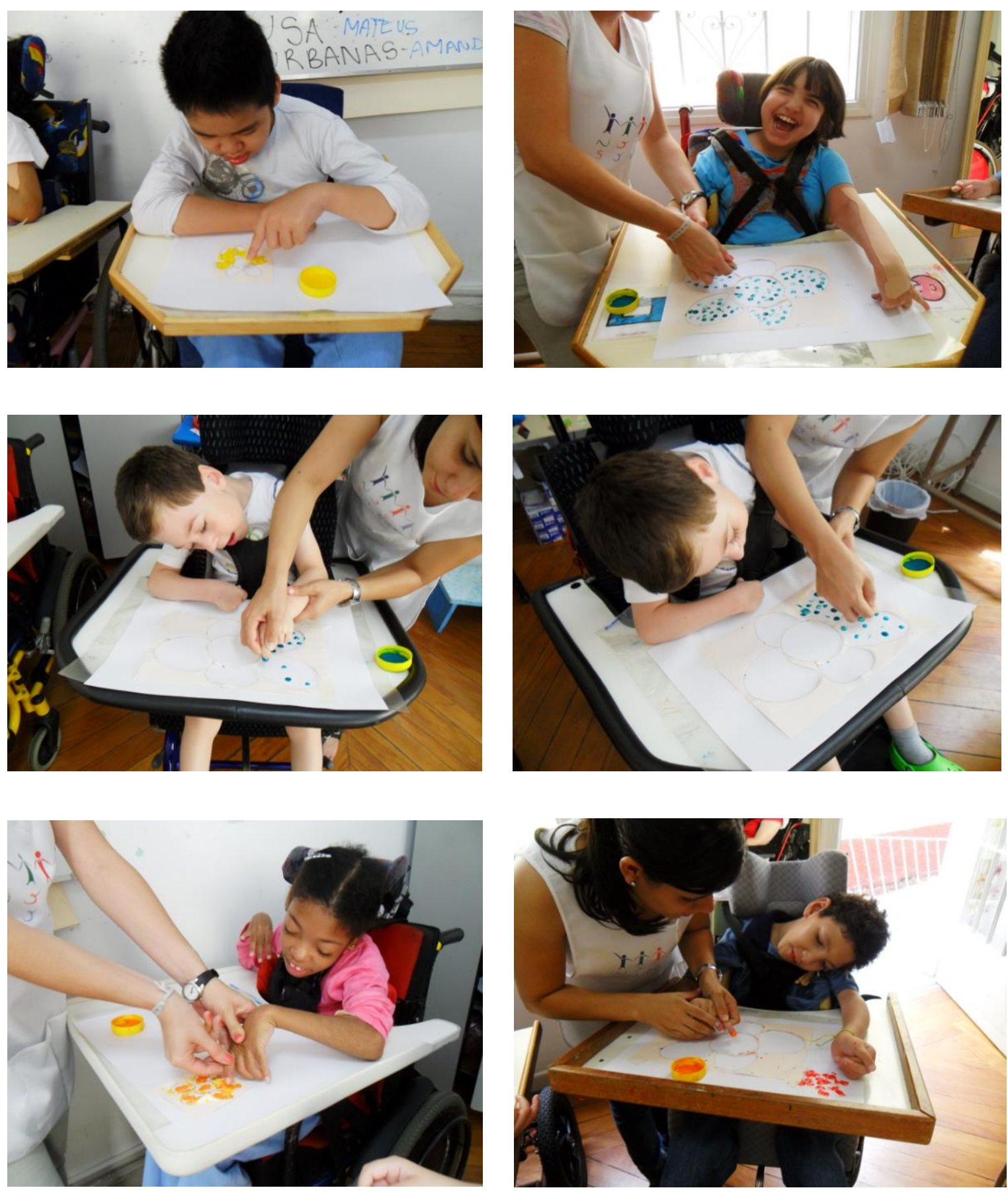

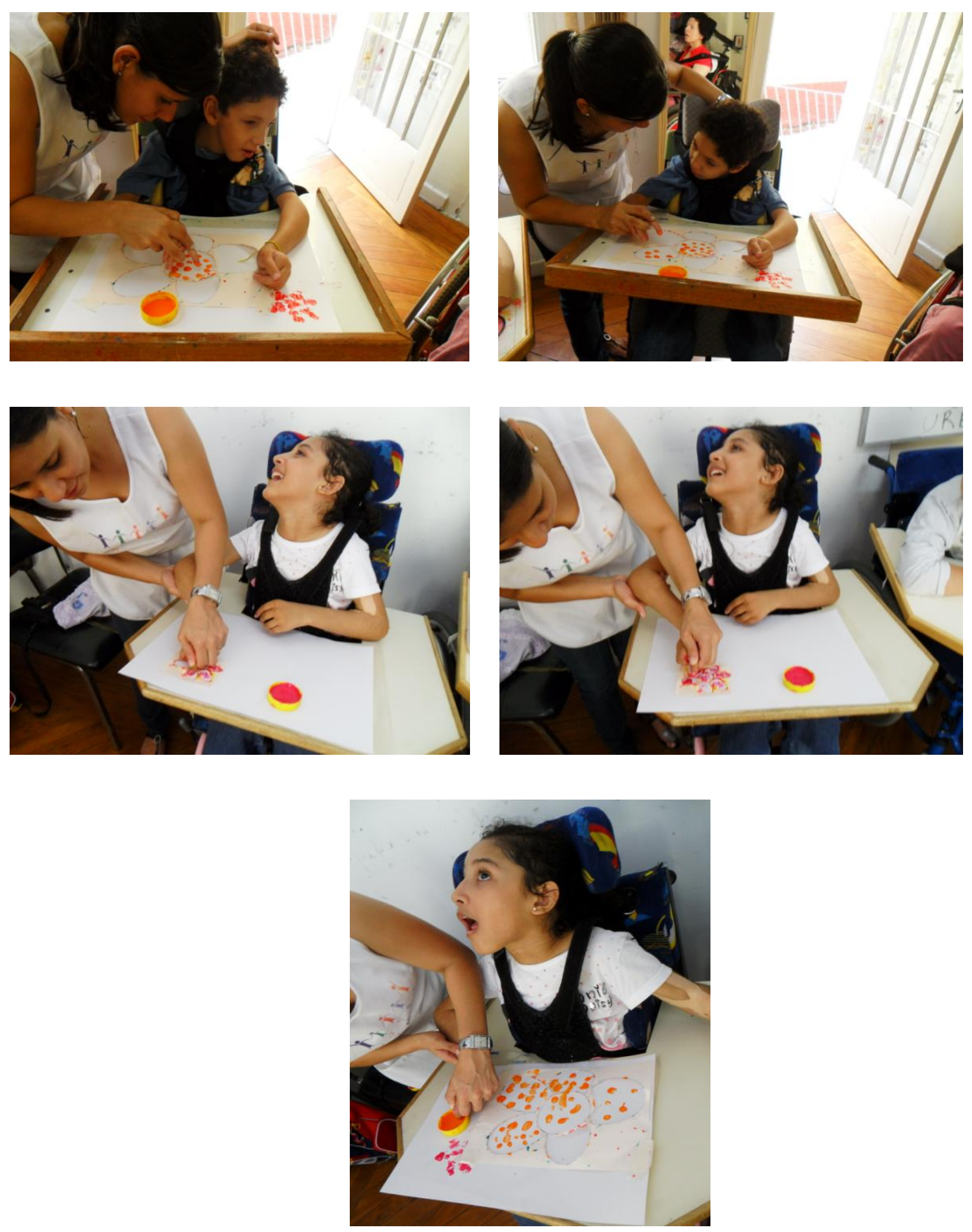

SEGUEM-SE FOTOS DA VISITA À EXPOSIÇÃO DE ERNESTO NETO NO MAM, A QUAL INFELIZMENTE SÓ AMANDA E EU PUDEMOS IR. 

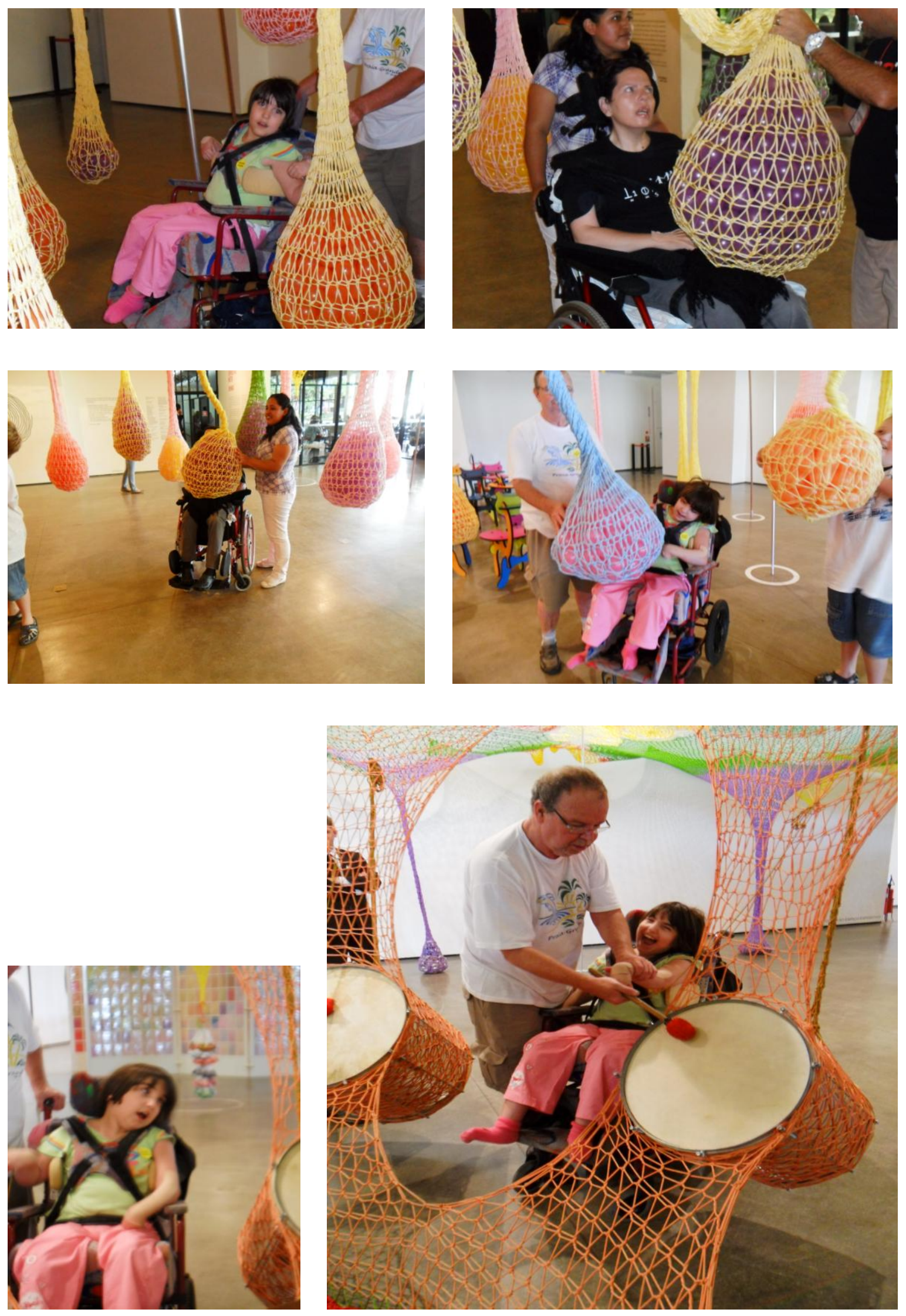

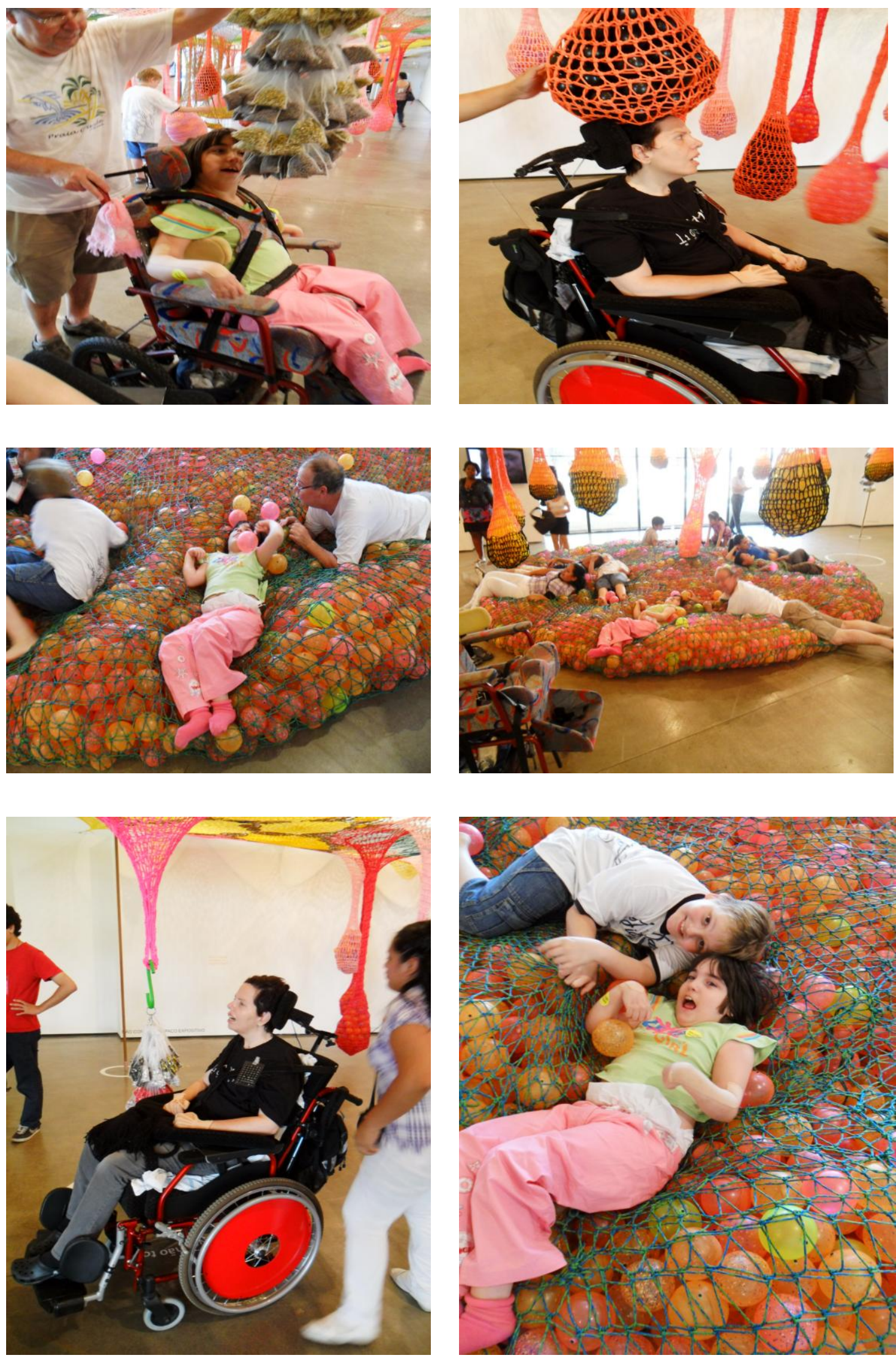

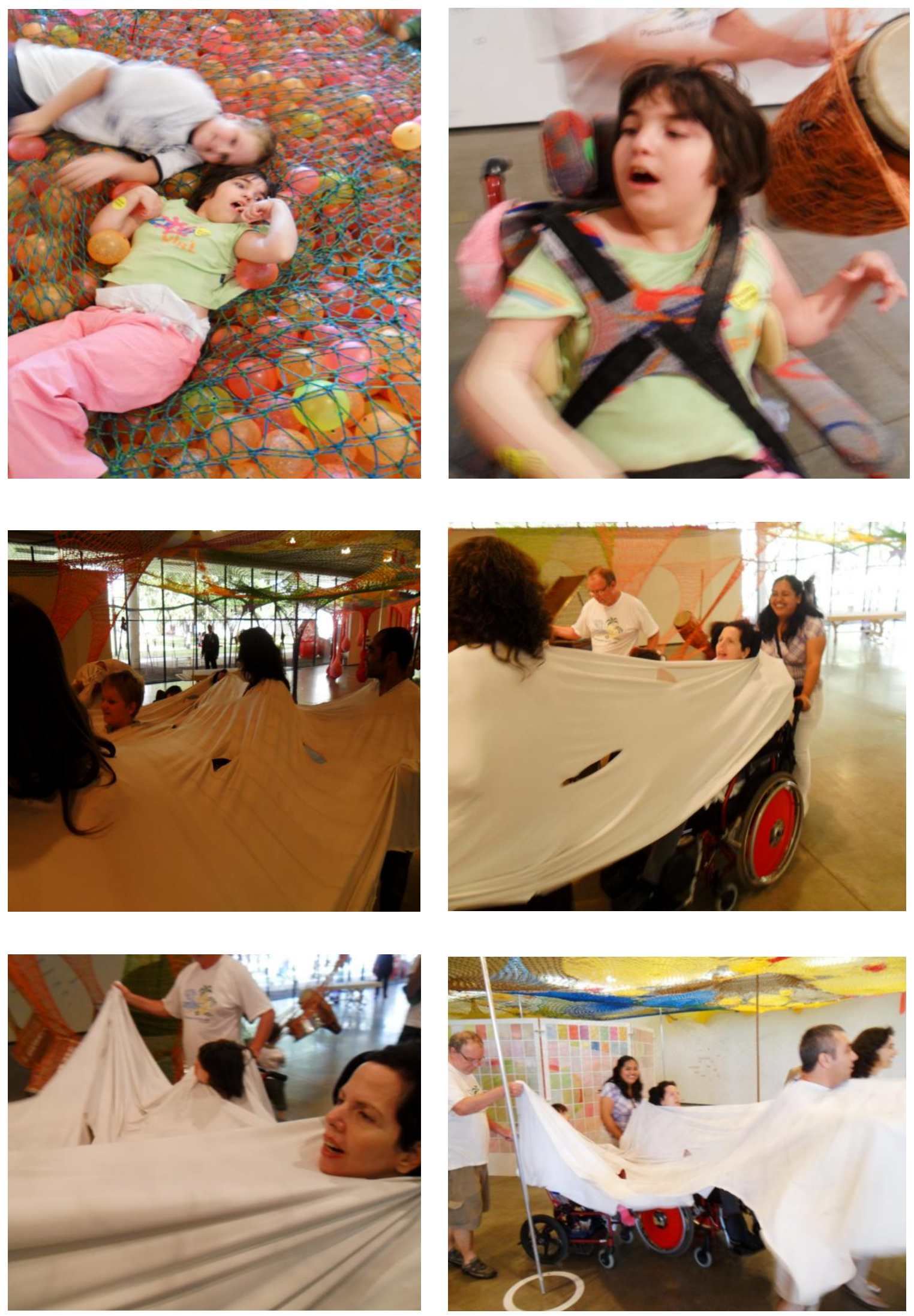

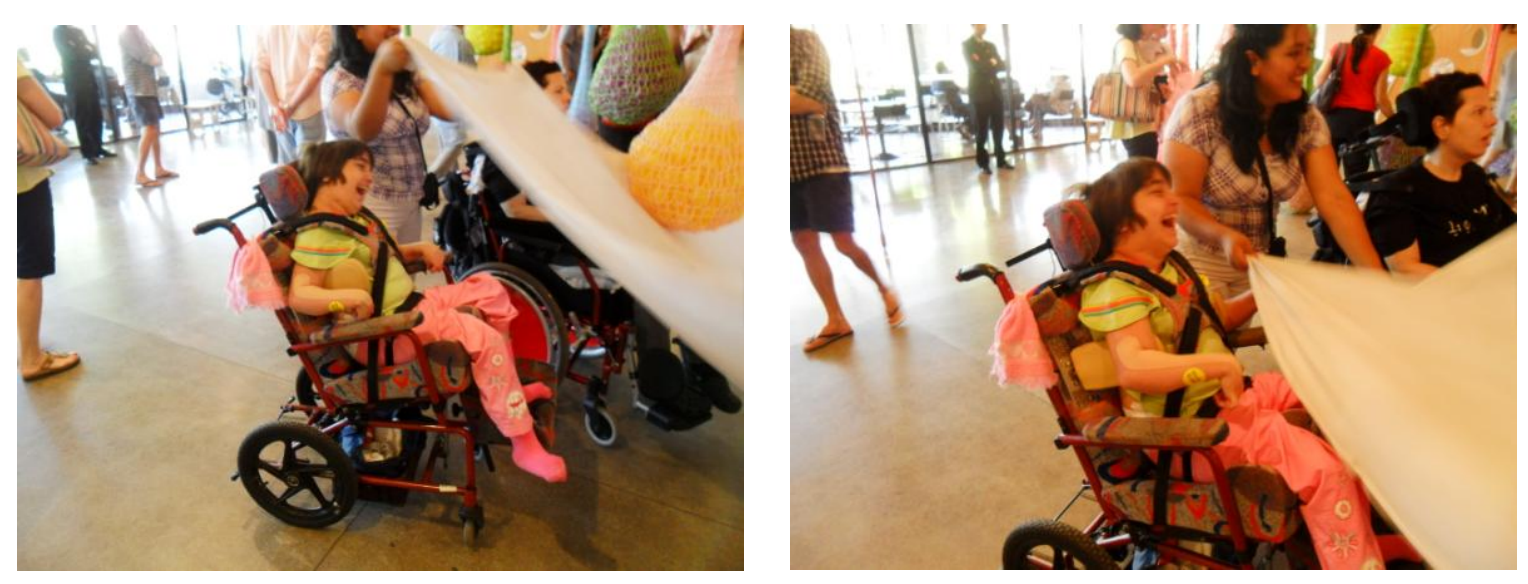

OLÁ CRIANÇAS

VAMOS CONTINUAR NOSSO TRABALHO PONTILHISTA: PEGUEM O TRABALHO QUE VOCÊS FIZERAM NA AULA PASSADA, ESCOLHAM UMA COR QUE CONTRASTE (QUE SEJA DIFERENTE) COM AS MARGARIDAS. VOCÊS VÃO PINTAR O FUNDO COM AS PONTAS DOS DEDOS.

(PAUSA, NÃO LEIA TUDO DE UMA VEZ, FAÇAM OS FUNDOS E DEPOIS CONTINUE)

AGORA VAMOS PENDURAR TODOS E OLHAR.

(PAUSA PARA OLHAR)

VOCÊS ACHAM QUE FICARAM CONTRASTANTES?

(RESPOSTAS)

PRÓXIMA AULA TEM MAIS!

ANA AMÁLIA

$07 / 12 / 2010$ 

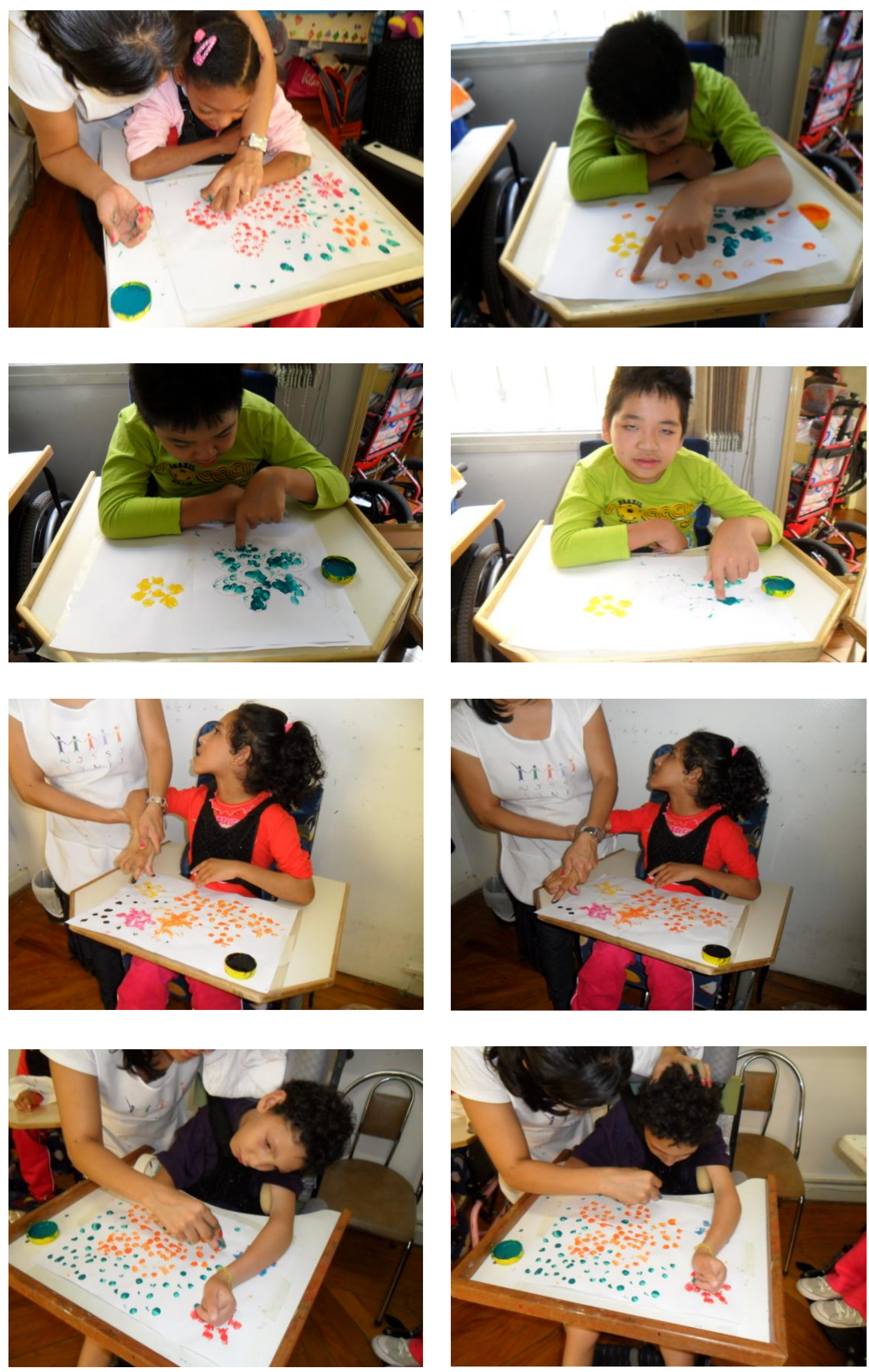

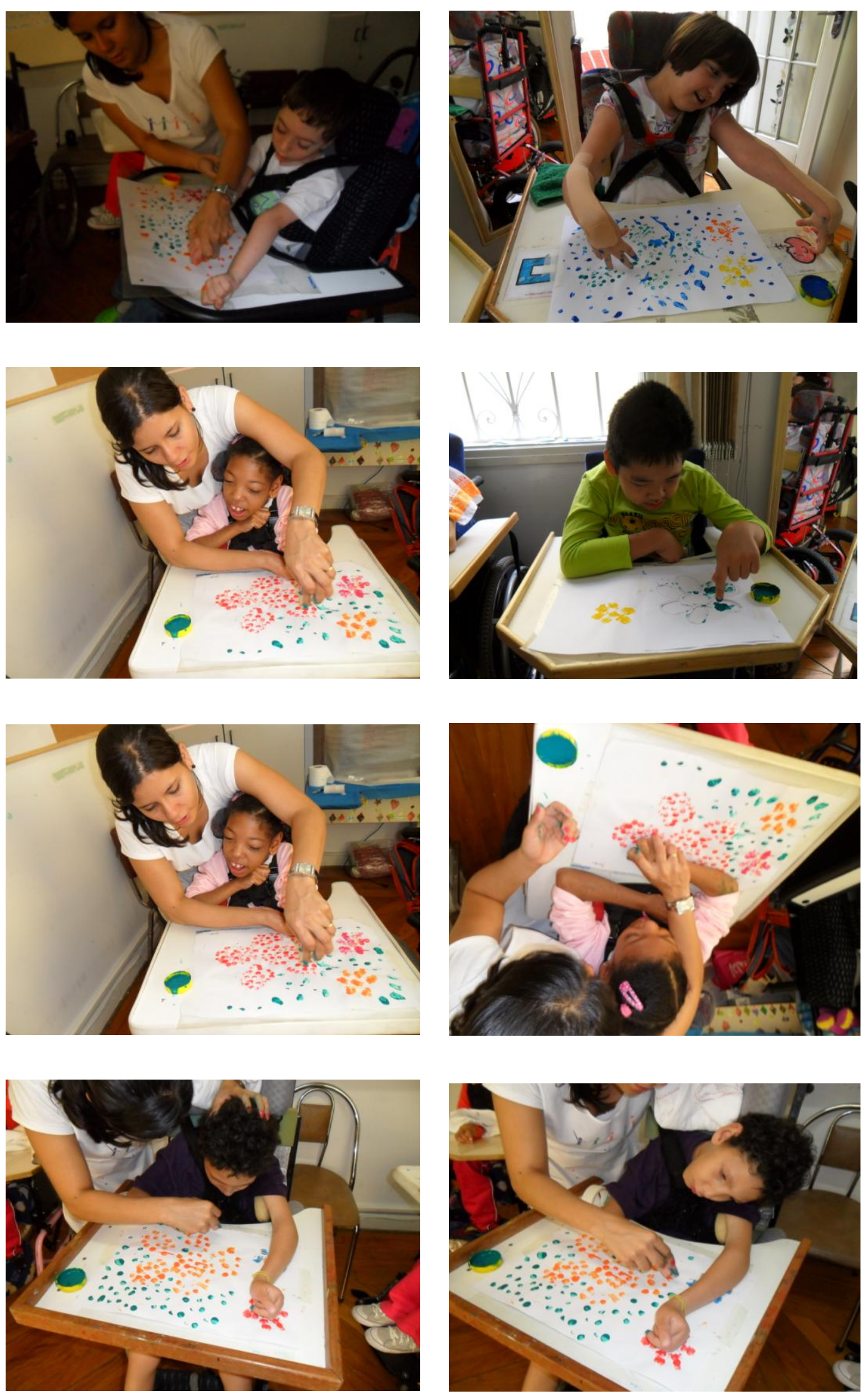

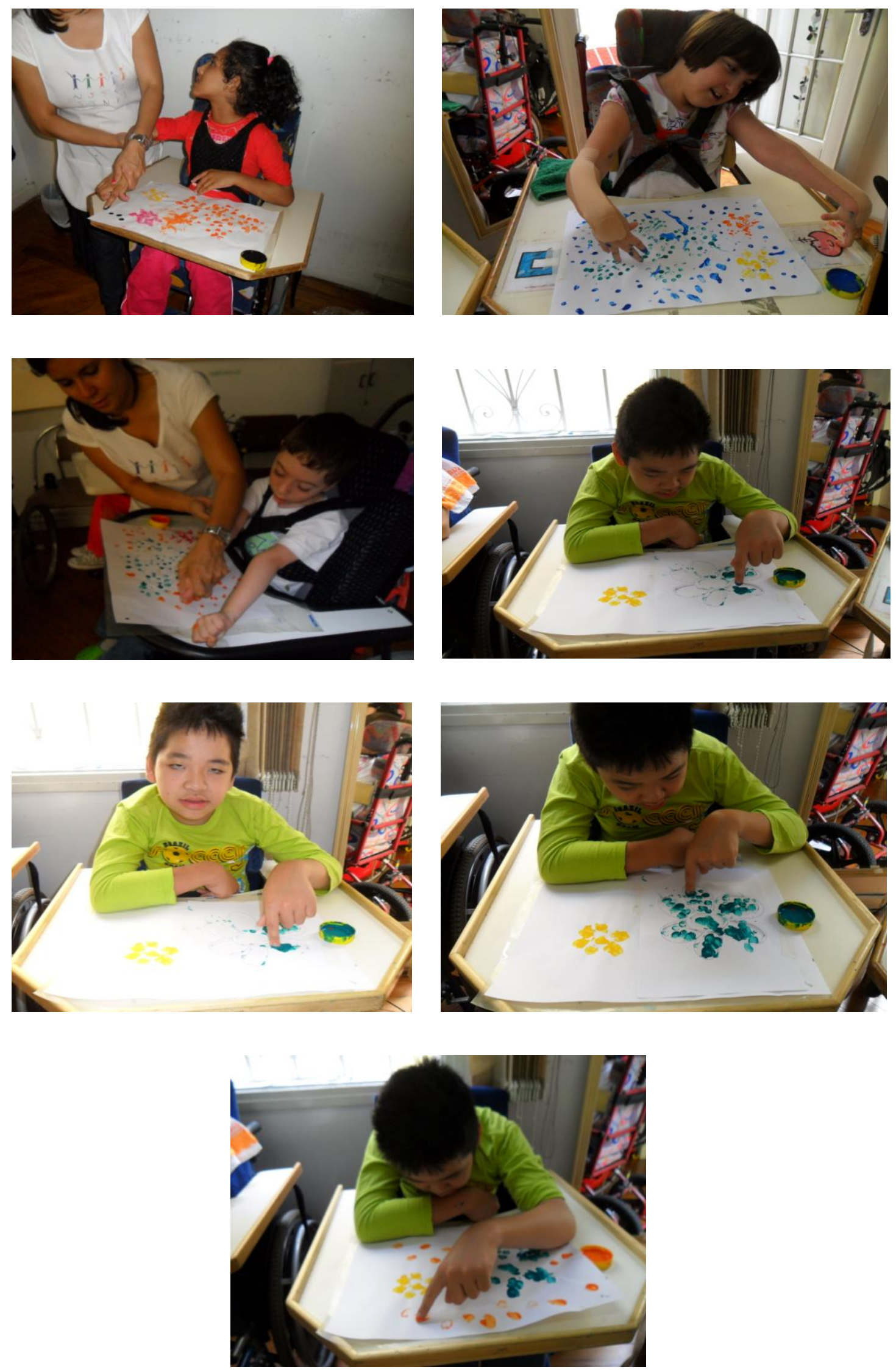


\section{OLÁ CRIANÇAS}

HOJE EU TROUXE UM POWEPOINT QUE EU FIZ SOBRE O PONTILHISMO PRA VOCÊS.

SE FOR POSSÍVEL, GOSTARIA QUE VOCÊS PASSASSEM OS SLIDES.

(PAUSA PARA PASSAR O PPT)

COMO EU JÁ DISSE, BOAS FERIAS! DIVIRTAM-SE! DESCANSEM! E VOLTEM COM O PIQUE TOTAL!

ANA AMÁLIA

$14 / 12 / 2010$ 


\section{CAPITULO 2}

\section{COMO OS OUTROS VEEM O MEU TRABALHO E O DAS CRIANÇAS.}

A professora Regina Stela Barcelos Machado minha orientadora sugeriu que eu submetesse minhas aulas a educadores, psicólogos, artes educadores, artistas, para receber deles sugestões, avaliações, reações, enfim dialogar com pessoas mais experientes do que eu. Trata-se de um procedimento o qual usei no mestrado que é validado pelos métodos de pesquisa etnográficos segundo Mary Stokrocki (2008). Hoje quando se fala de realidade penso que está se falando da diferen-

ça entre a maneira como eu me vejo e os outros me veem. É essa distancia entre minha avaliação do que faço e a avaliação do outro que constitui uma avaliação autentica no dizer de Enid Zimmerman (2008). Segundo esta autora a avaliação autentica é avaliação que estende para mais além o processo de aprendizagem.

Os mais bem-sucedidos processos de avaliação autêntica requerem a colaboração de professores, estudantes e membros da comunidade local, embora a extensão dessa colaboração dependa de vários fatores: o ambiente educacional local, a natureza e a diversidade da população estudantil, as filosofias e estratégias preferidas pelos professores e as diretrizes locais com respeito ao conteúdo e à administração do programa. (ZIMMERMAN 2008)

Foi no sentido não só de validar o meu trabalho pois, as inseguranças de uma pessoa em minha situação física são grandes,mas principalmente no sentido de ampliar meu campo de referências,melhorar meu trabalho e dele conseguir o máximo de resultados positivos para meus alunos que elaboramos minha orientadora e eu primeiro uma lista de professores especializados a quem submeter meu trabalho. A psicóloga eu não conheço mas mesmo assim ela deu uma longa e alimentadora resposta. A segunda lista que elaboramos foi de pessoas da comunidade Nosso Sonho e por fim uma terceira lista incluiu pais de alunos.

Enviei para os especialistas os PPTs das minhas aulas e fotos dos alunos trabalhando sem justificativa teórica nem explicitação de metodologia.

Apresento aqui as respostas primeiro dos especialistas.

A primeira resposta que me chegou foi do professor Luis Carlos Menezes, do Instituto de Física da USP, um educador político que participou da secretária de Educação do Município de 
São Paulo quando Paulo Freire foi secretário, foi ativíssimo na redemocratização da USP após a ditadura, fez várias pesquisas na rede de ensino estadual de São Paulo e é um cientista que valoriza a colaboração da arte na educação.

\author{
Ana Amália - A Educação pelo Corpo \\ Luis Carlos de Menezes \\ Físico e Educador \\ na Universidade de São Paulo
}

Minha amiga Ana Amália Barbosa, por força de um acidente vascular cerebral, há alguns anos perdeu praticamente todos os movimentos, com poucas exceções como o das pálpebras, por meio das quais aprendeu a se comunicar em código, piscando os olhos. Logo que houve o acidente, achei que nunca mais falaria com ela, mas depois de um tempo, recebi um e-mail dizendo: "estou viva".

Retomamos assim nosso contato e ela vem me surpreendendo pelo engajamento com que discute os problemas do mundo, como as desigualdades persistentes e a supressão de direitos dos mais fracos. Tivemos alguns encontros, em exposições de arte, no funeral de seu pai, e no aniversário dela em que tive o privilégio de estar entre aqueles que reuniu em sua casa, não para marcar a idade, mas como ela explicitou, para celebrar a vida.

Em nosso encontro mais recente, acompanhei videogravações de um trabalho de educação para a arte que conduz com crianças tetraplégicas, em condições próximas à imobilidade radical que tão bem conhece. Minhas impressões sobre esse trabalho eu as descreverei a seguir, procurando mostrar, mais uma vez, a sua capacidade de me surpreender e me ensinar lições que, aliás, continuam ecoando em outras lições que só aos poucos se desvelam.

É difícil para qualquer um admitir preconceito, relativamente a pessoas com deficiências severas, mas um amigo próximo me confessou lhe ser quase impossível conviver com quem não se move e, em especial, com quem é incapaz da fala, do sorriso, e de revelar no rosto tristeza ou raiva. Ele deixou entrever seu constrangimento, ou medo, por conta dessa falta de contato, que o faz sentir-se diante de uma esfinge. Penso, retrospectivamente, que ele teme algo que o reporta a situações pregressas de falta de comunicação, talvez secretamente recalcadas. Pude entendê-lo e, naquele momento, me senti menos limitado do que ele. 
Relato isso para falar de uma visão equivocada, de uma falta de percepção minha, corrigida quando observei o trabalho de Ana Amália. Indo direto ao ponto: eu sempre me encantei com a riqueza de sua vida interior, alimentada por intensa e ativa atenção dada ao mundo à sua volta, mas eu a via como uma espécie de espírito desencarnado, como se, por assim dizer, seu corpo tivesse se tornado irrelevante. Essa compreensão empobrecida me levava até a me questionar se faria sentido beijar-lhe a face, ao nos encontrarmos ou nos despedirmos, e a temer lhe perguntar sobre sua sensibilidade de pele, seu olfato e seu paladar; curiosidade que eu de fato tinha. Mal entendia o sentido de suas sessões de fisioterapia. Preconceituoso, eu também?...

Pois bem, posso contar agora o que aprendi, vendo o trabalho com as crianças tetraplégicas. Logo percebi que não se tratava de simplesmente mostrar a essas crianças a arte dos outros, que um incauto como eu imaginaria ser o caso: não lhes serviria só ouvir falar de uma cultura plástica cuja prática lhes escaparia eternamente. À professora Ana Amália não bastava que elas conhecessem a arte consagrada, feita com a mão dos outros, com o gesto dos outros, com o corpo dos outros. Tratava-se, isso sim, de lhes encher as mãos com tintas de muitas cores, de deixar que marcassem e desenhassem, em papéis e pedaços de cartão, o que imaginavam ou o que observavam, e isso de tal forma que suas limitações, mesmo que às vezes contornadas com algum auxílio, não eram mais limitações, mas autênticas e genuínas formas próprias de expressão.

E não ficava nisso; o corpo das crianças era também lambuzado de belas cores e "carimbado" em amplos papéis, que eram em seguida expostos aos artistas, felizes diante de sua criação... E quando outros artistas eram convidados para fazer seus desenhos, lhes ofereciam como suporte, como tela viva, o próprio corpo das crianças. Mas essas crianças não seriam como Ana Amália, elas também espíritos desencarnados? Cérebros puros transportados em carrinhos? Não! Seus corpos sensíveis, únicos, eram capazes de ganhar outras formas, quando projetados em um plano, de assumir outro aspecto quando rabiscados e coloridos. E o acervo assim produzido, desenhos e fotos expostos nas paredes, pendurado em painéis, enchendo o espaço do ateliê, mais do que o testemunho concreto dessa materialidade era uma obra coletiva, dinâmica, permanentemente revista e refeita. E olha ali meu tronco azul e minhas pernas amarelas!

Esse trabalho com as crianças tem também outras dimensões, que poderiam ser descritas com maior riqueza por quem entenda de arte e de crianças mais do que eu e, por isso trouxesse outra elaboração além da que eu sou capaz. Aliás, por falar literalmente em dimensões, para ilustrar a passagem das duas dimensões dos desenhos e pinturas, para as três da escultura, houve uma 
visita à Pinacoteca. Em uma conversa ilustrativa com um bom professor de arte, no parque ao lado, transitou-se de um papel amassado com as mãos para uma gigantesca peça de mármore, diante da qual minha amiga Ana Amália meditou longamente.

Nada tenho de místico, mas percebi em seu trabalho uma sagração, cujo alcance transcende as circunstâncias das deficiências e deve ser mais compreendido, para ser generalizado nos fazeres da educação. Eis o comentário com que concluo este depoimento. No entanto, preciso agregar um ponto a meu relato, mais marcado pela emoção do que pelos conceitos: Não quero deixar de registrar a enormidade do esforço para por em prática cada atividade que vi. Cada ação com seu grupo de alunos é uma batalha, como a que Ana Amália trava com os transportes públicos, cuja desatenção às necessidades daquelas crianças lhes sonega direitos.

Foi muito importante para mim o entendimento que o Prof. Menezes teve da relação entre a expressão de meus alunos e a alfabetização cultural que eu estava promovendo.

Outro texto avaliativo veio de Cláudia Simas arte/educadora do hospital Sarah Kubitschek de Brasília, sua dissertação de mestrado na UNB foi a analise de um trabalho com um paciente com "lesão cerebral e significativo comprometimento do domínio da linguagem, sua trajetória de reconstrução e ampliação da capacidade de comunicação por meios de recursos compreendidos no campo das artes plásticas" (SIMAS 2008, p. 135) que está descrito no livro Interterritorialidade, mídias contexto e educação (Barbosa e Amaral orgs., 2008)

Ana Amália, em reunião de equipe apresentei o seu trabalho para três professora de arte, para que pudéssemos trocar impressões e compartilhar ideias com você.

Como profissionais de arte-educação, que não acompanham o processo relatado na tese, sentimos falta de alguns elementos narrativos sobre o fazer individual de cada criança. Compreendemos que seu trabalho esteja calcado em sua experiência prática, no entanto acreditamos que se faz necessário uma abordagem metodológica mais objetiva. Ao que podemos perceber é possível trabalhar mais na apresentação o que toca a delimitação do objeto de estudo da pesquisa, ou seja, pontuar mais sobre o que trata o estudo: o foco da pesquisa é a experiência corpórea e estética dos alunos ou a experiência educacional iniciada por você?

Outra questão que nos parece merecer mais atenção na estrutura de sua tese é a delimitação entre objetos de estudo que necessitam de uma abordagem crítica relacionados à questão da leitura visual (o que, a princípio, diria respeito aos produtos finais) e objetos de estudo que necessitam de uma análise mais 
aprofundada no tocante ao processo criativo seu (o que e como essa experiência modificou a sua noção de corpo tanto em sua própria espacialidade quanto no encontro com os alunos) e a experiência do outro (no caso, as crianças envolvidas: o que sentem, como se percebem, o que falam, como trabalham e o que motivou suas escolhas).

Ainda sobre as escolhas gostaríamos de ressaltar a importância de uma narrativa sobre a adequação de procedimentos e materiais mais eficientes para a experimentação visoconstrutiva da criança. É importante observar cada criança, pontuar suas limitações, apresentar possibilidades e acompanhar a evolução das mesmas (demonstrando imageticamente a produção e por meio de depoimentos orais e escritos experiências individuais e coletivas).

Entendemos que ao definir mais claramente o sujeito da ação, seu campo de ação intelectual será menos abrangente e, por consequência, seu aprofundamento será mais expressivo.

Ana, entre o material apresentado nos chamou muita atenção a questão da necessidade do reconhecimento de que, hoje com o suporte tecnológico não precisamos nos restringir as imposições determinadas pelas limitações do corpo. Os recursos que hoje permitem ao sujeito ultrapassar barreiras, estão ligados a tecnologias (cadeira motorizada, computadores e programas, celulares e máquinas digitais, dentre outros) que podem ser abordadas de forma mais positiva ao longo texto. O que se fará necessário seja pela sua abordagem com os alunos, seja pela escolha de usar ou não tais recursos em sala de aula.

A equipe de arte do Hospital Sarah agradece o envio do material e a oportunidade de acompanharmos e podermos refletir sobre práticas de arte-educação que nos são tão caras em outros espaços que não somente os deste hospital.

Aline Ribeiro Galvão - Professora de Arte-educação formada pela UnB

Claudia Gunzburger Simas - Professora de Arte-educação pós-graduada pela UnB

Mirelle Viana Veríssimo - Professora de Arte-educação formada pela UnB

Thaís Paranhos Nascimento - Professora de Arte-educação pós-graduada pela PUC-Rio e CP$\mathrm{DOC} / \mathrm{FGV}$

Analise de Cláudia Simas e suas companheiras de trabalho ajudou a definir melhor o que faltava explicar. Não havia escrito ainda a introdução, portanto as circunstancias envolvidas não estavam explicitadas. A metodologia da pesquisa e meus objetivos não estavam explicitados. Queria explorar as possibilidades de se entender os procedimentos através de texto sumário inter- 
relacionado com as imagens. Queria testar as possibilidades do Arts Based Research in Art Education como demonstração de pesquisa. Acredito que a introdução agora esclarece muitos pontos requeridos pela análise de Claudia Simas, Aline Ribeiro Galvão, Mirelle Viana Veríssimo, Thaís Paranhos Nascimento. O que apontei, mas decidi não esclarecer na Introdução foi a metodologia usada em sala de aula com os alunos. Deixei pra explicita-la em resposta a arguta análise das arte/educadoras do Hospital Sarah Kubitschek de Brasília. Escolhi trabalhar com a Abordagem Triangular por que ela inter-relaciona a arte como expressão,como cultura e como fenômeno social através do fazer artístico que leva a organização do pensamento, ao desenvolvimento da percepção visual e no caso do meu trabalho leva a percepção do corpo por inteiro além de explorar o contexto no qual se vive e se cria.

A ampliação do conhecimento e dos usos da cultura é explorada através de ver e analisar imagens produzidas por outros, artistas contemporâneos, ou canônicos, ocasião em que também se estende a interpretação para o contexto no qual a obra foi criada e para o contexto do interpretante.

Outro texto avaliativo impactante foi o da psicóloga Maria Cristina Kupfer que é Professora Titular do Instituto de Psicologia da Universidade de São Paulo e Presidente do Conselho de Administração da Associação Lugar de Vida - Centro de Educação Terapêutica. Como parte de seus trabalhos na USP criou e permanece editora da revista Estilos da Clínica; Revista sobre a Infância com Problemas. Atua principalmente nos seguintes temas: psicanálise, infância, educação especial, psicose e autismo. É autora de vários livros sobre psicanalise e educação.

Arte e imagem corporal

Não tive a oportunidade de conhecer pessoalmente Ana Amália. Mas quando sua orientadora pediu-me para registrar este depoimento, surpreendi-me procurando, nas fotos que encontrei no volume de sua qualificação, a imagem de Ana Amália: queria ver seu rosto, sem saber muito bem por que.

Em seguida, fui buscar, entre os temas que estudo atualmente, aquele com o qual pudesse fazer o comentário pedido por sua orientadora. São muitos esses temas, porque há 20 anos sou sacudida pelo desafio de tratar e educar crianças com problemas de desenvolvimento, aquelas que 
hoje são chamadas de crianças com TID (com transtornos invasivos do desenvolvimento), mas que prefiro chamar de autistas e psicóticas.

O tema que escolhi? Pensei em falar do trabalho que Ana Amália faz, por meio da arte, com a imagem corporal das crianças com paralisia cerebral.

Aprendi, com a psicanálise, que existe uma imagem corporal que construímos desde bebês na relação como os cuidadores, e em especial com a mãe. Essa imagem, essa representação mental, psíquica, de nosso corpo, não corresponde necessariamente e ponto por ponto ao nosso corpo real. É uma espécie de lâmina libidinal que reveste imaginariamente o corpo, e que ganha contornos mais ferozes ou mais sutis de acordo com o modo como fomos tocados por esse cuidador. Fazemos também uma interpretação do sentido que esse cuidador deu a cada um desses contornos, desses buracos, de suas reentrâncias e saliências. E nosso eu se ancora, se apoia, nessa imagem, ele é essa imagem que fazemos de nós, uma imagem que é essencialmente e substancialmente corporal. E quando nos dirigimos aos outros, dirigimo-nos orientados por essa imagem corporal, já que a sua construção foi pilotada pelo outro cuidador, que lhe deus seus primeiros sentidos e interpretações.

As crianças autistas têm essa imagem corporal prejudicada, muitas vezes por problemas constitucionais. Embora se movimentem e saibam usar muito bem seu corpo real, sabemos que essa imagem, feita principalmente para orientar a relação com os outros, não está presente. Disso decorrem muitas de suas dificuldades, e o trabalho terapêutico e educativo visa a uma reconstrução, ainda que parcial, dessa imagem. Isso precisa ser feito "ensinando-as" a entrar em contato com os outros por meio do contato prazeroso, do toque sensível, um toque que fazemos com a palavra. Elas precisam saber que as pessoas entram em sintonia umas com as outras graças a esse registro prazeroso, agradável, que o toque e a palavra cheia de ternura da mãe ajudam a construir sobre o corpo de seu filho.

Ana Amália nos contou que as crianças com paralisia cerebral têm a noção espacial e de conhecimento do corpo prejudicada. Embora não trabalhe com crianças com paralisia, tendo a concordar com ela. Aprendi que o corpo desde cedo limitado por perturbações de alguma ordem pode colocar obstáculos nesse trabalho de libidinização e de construção da imagem corporal. Anda que uma mãe fale com ternura, manipule o corpo da criança, transmitindo boas sensações, e ajude seu filho com paralisia a construir o mapa libidinal de seu corpo, ainda assim a paralisia pode diminuir ou impedir a recepção nervosa adequada, assim como o registro sensorial desse 
trabalho libidinal. Além disso, as crianças que exigem muitos cuidados médicos acabam registrando significações para seus corpos que são significações desprovidas desse sentido relacional: seu corpo não é muitas vezes a sede dos cuidados que o embelezam e o tornam agradável aos olhos dos outros, mas a sede dos cuidados médicos e assépticos em que predomina a preocupação, muitas vezes inevitável, com a limpeza, o exercício, a fisioterapia. O corpo é o lugar sobre o qual se concentram intervenções cirúrgicas, e é encarado como um objeto que é preciso corrigir o tempo todo.

Assim, são crianças que devem ter, em alguma medida, uma alteração de sua imagem corporal.

Ana Amália não está preocupada com essa dimensão, essa da imagem corporal. Ao contrário, quer mostrar para as crianças com paralisia cerebral que "dá pra viver bem sem andar ou falar", ou seja, sem colocar o corpo em questão no contato com os outros. Mas quero sugerir que o corpo das crianças, e também o de Ana Amália, estão entrando, sim, nesse trabalho. Não necessariamente o corpo, mas a sua imagem.

Mais adiante, ela diz: "Eu ensino arte, mas tô começando a achar que Arte é apenas a ponta do iceberg. No fundo, vou mais longe". Aqui eu a estou ouvindo dizer: "Eu quase que nada não sei. Mas desconfio de muita coisa", como disse Riobaldo em Grande Sertão Veredas. Sim, o trabalho de Ana Amália pode ser terapêutico, embora ela não se proponha a isso.

Ana Amália desconfia que está fazendo mais do que ensinar arte. Fico espantada e maravilhada ao pensar que ela está reconstruindo a imagem corporal das crianças com paralisia cerebral sem falar e sem tocar nelas, ao contrário do que faria uma mãe ou um terapeuta. Só que ela as toca e fala com elas...por meio da arte; fazendo falar a arte. Ela lhes propõe, por exemplo, que se lambuzem de tinta e que rolem no chão. Disso sairá um produto: um contorno, uma imagem, uma expressão. Uma fala, um sentido atribuído, uma interpretação dada pela criança e apresentada para os olhos de seu espectador. Uma coisa muito bonita: ao mesmo tempo em que aprendem o que é produzir um discurso expressivo, um ato de arte, uma fala dirigida ao outro a respeito de sua posição (aqui, corporal) no mundo, elas constroem, no mesmo ato, a si próprias! Não é isso que faz um artista constantemente? Não há, em cada ato de arte, uma reinterpretação de si, uma renovação de seu sentido, uma nova compreensão, uma criação que o atravessa, e que pode inclusive atravessar seu corpo e a imagem que esse artista faz dele? Ao mostrarem a "interpretação" de seu mapa corporal, ao submeterem esse mapa aos olhos dos outros, as crianças de Ana Amália estão construindo a libidinização de seus corpos. E não somente nos trabalhos em que se lambu- 
zaram inteiros de tinta. Fazem-no também nos desenhos e pinturas, uma vez que o gesto neles também está presente, e também esses desenhos são postos para serem olhados. Estão fazendo como os bebês, que se comprazem ao serem olhados por suas mães e ganham, nesse mesmo golpe, presença no mundo, significação e imagem corporal! Ao serem olhadas, por meio de seu trabalho, elas ganham, em uma palavra, vida!

Não consegui ver com clareza o rosto de Ana Amália, que aparece aqui e ali nas fotos que ilustram o seu texto. Mas não foi preciso: deu para perceber que sua imagem corporal, aquela construída há muito tempo em sua vida e que serve entre outras coisas para relacionar-se, não está perdida. É por meio dela que ela ensina arte e reafirma a sua presença no mundo: uma presença que, por meio do ensino da arte, fala e anda!

Esse texto de Maria Cristina Kupfer me mostrou o que eu não sei, mas que agora gostaria de saber sobre a psicanalise. Na minha ansiedade para me definir como arte/educadora e não arte terapeuta me afastei das teorias psicanalíticas, mas para entender o corpo que sofre,que é objeto de interversões dolorosas é preciso saber mais e enveredar pelo caminho que Maria Cristina Kupfer me apontou. Cheguei a fazer duas disciplinas na Pontifícia Universidade Católica de São Paulo, em frente a minha casa, o que facilitava a locomoção, na área de Psicologia do Desenvolvimento antes de me matricular para o Doutorado na Universidade de São Paulo. Aprendi muito, fui tão bem recebida que mudaram a classe de sala para que eu tivesse acesso às aulas, embora fosse aluna ouvinte, mas não foi o bastante.

A negação do embelezamento do corpo que sofre do qual Maria Cristina Kupfer fala, foi a experiência que tive no meu primeiro ano depois do AVC. Fui aprender no Hospital Sarah $\mathrm{Ku}-$ bitschek de Brasília que me vestir bem, pintar os lábios e usar sapatos, embora não ande é um processo de dignificação do corpo que faz parte das terapias de reabilitação. A reabilitação pela qual passei no Hospital Sarah Kubitschek foi uma reabilitação como ser humano, muito além de uma reabilitação motora que se mostrou quase impossível no meu caso. Passei a escolher cuidadosamente minhas roupas numa forma de respeito a mim mesma e aos que convivem comigo.

Já comentei os textos do cientista educador, das arte/educadoras especializadas em reabilitação, da psicóloga e agora introduzo o depoimento analítico do artista Darlan Rosa. Ele é casado com uma arte/educadora, Célia Rosa, muito influente nas escolas de Brasília, engajada nos movimentos de politica publica em defesa da arte/educação, atualmente participante da diretoria da Federação de Arte Educadores do Brasil, apesar de aposentada. 
Darlan Rosa trabalha com arte publica e podemos encontrar na cidade de Brasília muitas de suas esculturas em prédios e no monumento JK. Expõe frequentemente no exterior principalmente na França, Estados Unidos e Canadá.

É também artista gráfico e trabalhou para a UNESCO na recuperação de Angola em várias campanhas educacionais e de saúde.

Prezada Anamália,

Desculpe a minha demora em responder, mas estava envolvido com uma exposição aqui em Brasília

Célia e eu achamos fantástica a maneira como v. está trabalhando a arte com criança deficiente física. Além do prazer de exercitar a criação e a construção de um pensamento visual, com certeza valoriza muito a alta estima deles. Quanto a questão de se usar o computador ou os processos tradicionais de pintura e desenho, pensamos que se pode utilizar um para complementar o outro ou alternar esta utilização de acordo com a demanda.

Os desenhos feitos pelo contorno das crianças e posteriormente pintados com faixas de várias cores nos parecem muito expressivos e muito plásticos. Vemos neles uma manifestação de movimento muito grande. Como se as crianças quisessem através do desenho realizar os movimentos de que elas foram privadas.

É aí que eu me atrevo a fazer a seguinte sugestão: A partir dos desenhos desenvolver pequenas animações como: andar dançar levantar e baixar os braços ECT. Para fazer uma animação simples bastam 3 desenhos. Por exemplo: Braços em cima; braços no meio do corpo e braços abaixados. Estes desenhos seriam importados dentro de um software de animação e ai é só escolher a velocidade do movimento e salvar como um arquivo para o Windows média. Em anexo estou enviando um exemplo de uma animação feita a partir dos desenhos de suas crianças. (vide cd anexo)

Me perdoe se estou me intrometendo na sua pesquisa. Se precisar de ajuda com as animações, escolha do software estou a disposição.

\section{Beijos \\ Darlan}


A ideia de Darlan Rosa de trabalhar com animação é um desejo meu há algum tempo, mas não temos no Nosso Sonho computadores. Meu próximo passo além de estudar psicanalise é conseguir computadores para as crianças.

Concordo com Darlan Rosa e com as arte/educadoras do

Hospital Sarah Kubitschek de Brasília que as tecnologias contemporâneas são um instrumento essencial para a participação dos deficientes na sociedade. Graças as adaptações criadas para mim pelos engenheiros do Sarah Kubitschek de Brasília estou hoje escrevendo esta tese. Eles me libertaram do estado de "loked in" ao qual estava condenada.

Passo agora aos relatos do segundo grupo, os membros da comunidade Nosso Sonho:

Suely Katz (gerente da ONG Associação Nosso Sonho) diz:

Um dos objetivos da Associação Nosso Sonho é a inclusão de pessoas com deficiência no mercado de trabalho.

Ana é artista plástica com formação para desenvolver esse trabalho. Aconteceu uma intercorrência na vida dela, o AVC de tronco, mas seu potencial e sua formação permaneceram preservados, ,pois seu conhecimento na área não foi afetado, pelo contrario, sua condição de tetraplegia acrescenta no seu trabalho, uma vez que as crianças se identificam com ela, fazendo com que se motivem mais As famílias também ficaram mais motivadas ao verem o movimento da Ana vindo trabalhar.Trouxe esperança de que seus filhos também consigam atingir esse objetivo.

Crianças com paralisia cerebral tem a noção espacial e de conhecimento do corpo prejudicada. O projeto desenvolvido por Ana, promoveu e ampliou esse conhecimento nas crianças.

Acreditamos que a verdadeira inclusão ocorre quando aproveitamos o potencial e formação da pessoa e os utilizamos dentro de um projeto ou departamento. Nesse sentido, o trabalho da Ana Amália faz toda diferença no Nosso Sonho.

Sandra Carabetti orientadora pedagógica da Nosso Sonho escreveu a respeito do projeto de Arte o seguinte texto avaliativo:

Uma vez por semana as crianças da sala de pré alfabetização tem aulas de artes com a educadora Ana Amália. Já são quase 3 anos de atividades e a cada semestre temos novidades. Ana Amália consegue atrair a atenção do grupo mesmo sem emitir uma palavra! Ela é a expressão da força de vontade, criatividade e dedicação. As nossas crianças também não se locomovem e nem se comunicam da maneira tradi- 
cional; têm muito em comum com a educadora delas. Deve ser por isso que a admiram tanto, pois Ana Amália mostra a elas um futuro possível, um universo real de possibilidades! Se estão estudando formas geométricas, por que não ir ver de perto uma exposição? Todos no Instituto Tomie Ohtake. E se o conteúdo é volume, que tal um passeio no Jardim das Esculturas para apreciar ao vivo e a cores as obras expostas. E de volta à escola, o escultor Caito dando uma aula de escultura em biscoito. Dá para perder? Assim é Ana Amália... Depoimento em 2010.

A atual professora Tamires da Silva Oliveira que no início do trabalho era assistente também escreveu sobre as aulas de arte

“A Aula de artes com a professora Ana Amália tem sido de muita importância para nossos alunos. Ela traz para sala de aula assuntos interessantes e materiais diversificados, onde as crianças se interessam muito. A cada aula esperamos com expectativa para ver o que teremos de novidades, os alunos prestam muita atenção no que é passado e adoram a maneira como são feitas as atividades.

Sempre faz passeios onde as crianças se divertem e aprendem juntos. Suas aulas são muito importantes para todos nós do Nosso Sonho".

Depoimento 2010.

Passo agora aos depoimentos dos pais dos alunos:

Angela mãe do Henrique: a aula de artes despertou no Henrique um grande interesse por coisas normais do nosso cotidiano como cores, pinturas e desenhos. E cada vez que vê a bandeira do Brasil ele reconhece e logo abre um largo sorriso.

Maria mãe da Gabriela: O trabalho de artes foi muito importante para Gabriela pois ela descobriu atividades interessantes e a Gabi presta muita atenção nas aulas e gosta muito da Ana Amália.

Honorato pai da Amanda: Para Amanda foi ótimo pois ela gosta de artes onde ela pode fazer e sentir as coisas 
Lúcia mãe da Jenifer: Eu sou a Lucia mãe da Jenifer e deixo meu depoimento sobre a aula da Ana Amália, uma aula que leva ela para outro mundo, um mundo colorido e imaginário que todos estão descobrindo a graça. Ana Amália meu muito obrigada pela sua dedicação. 


\title{
CAPÍTULO 3
}

\section{QUASE CONCLUSÃO.}

O relato analítico das aulas em 2008, 2009 e 2010 está sendo concluindo, mas não meu trabalho com as crianças. Em 2011 continuei trabalhando com as mesmas crianças e anotando suas reações para posterior análise. Meus planos e os da escola é que eu continue com eles "ensinando Arte” em 2012. Tenho me perguntado com insistência: será que é isto mesmo que estou fazendo, “ensinar Arte"? Luis Camnitzer, (2011, p. 109) artista e arte/educador uruguaio que vive nos Estados Unidos e que foi curador do educativo de uma das Bienais do Mercosul me responde:

Em arte/educação “Arte não é realmente 'arte' mas um método para adquirir e expandir conhecimento".

Foi isto que busquei fazer com meus alunos. Todos eles estão sendo alfabetizados pelas professoras de classe.

\begin{abstract}
"Ambas, arte/ educação e alfabetização tem em comum a dual e frequentemente contraditória missão de um lado de facilitar a afirmação cultural e expressão individual e coletiva e de outro lado ser um instrumento necessário para cimentar e expandir formas de consumo" (CAMNITZER, 2011, p. 109.)
\end{abstract}

Estas formas de consumo são a leitura verbal e a leitura da imagem, no caso que estou expondo de ensino de Artes Visuais.

Se no modernismo dava-se no caso da alfabetização verbal mais importância à recepção, isto é mais importância a leitura que a escrita, algo expresso inclusive em ditos populares como “escreveu não leu o pau comeu”, na arte/educação visual dava-se mais importância a expressão. Hoje, o pós-modernismo pretende desenvolver equilibradamente a expressão e a recepção da arte na educação ou mais especificamente a Arte como expressão e como Cultura.

Para a ampliação da alfabetização cultural de meus alunos pretendi também desenvolver as estruturas da cognição compensatoriamente, estimulando os circuitos neurológicos a substituir funcionalmente regiões lesadas. Só uma abordagem interdisciplinar de arte/educadores e neurocientistas com o auxilio das novas tecnologias médicas como a estimulação magnética transcrania- 
na poderá comprovar se fui bem sucedida. Este tipo de comprovação é algo que pretendo perseguir no futuro, mas necessita de um volume de verbas raramente concedidas a arte/educadores.

Os meus alunos estão tendo grandes dificuldades em aprender a ler, mas todos os atores da educação que os rodeiam são persistentes e esperançosos.

A Academia Brasileira de Ciências. a Fundação Conrad Wessel e a Fundação Getulio Vargas organizaram uma conferência com renomados cientistas, inclusive um premio Nobel, James Heckman, acerca da educação infantil, alfabetização e cognição.

As Conclusões e Recomendações dessa Conferência (ARAÚJO, 2011) constituíram um livro muito valioso para mim porque é muito difícil encontrar bibliografia cientifica entendível por uma paciente leiga em neurologia que quer fazer alguma diferença com crianças portadoras de lesões cerebrais.

Em casos de perda de funções cerebrais "não só a perda da função relacionada à região lesada, mas também a desconexão do circuito envolvido naquela função" (CASELLA; AMARO JR, COSTA, 2011, p. 43) são influentes para a aprendizagem. Alias a permanência da conexão do circuito envolvido na cognição é mais importante do que a perda de uma função especifica.

Os mapas que dispõem as funções cerebrais, relacionadas a regiões especificas do cérebro como se este fosse um mosaico de funções, expõem limites precisos entre estas áreas funcionais, o que nem sempre corresponde à realidade... As áreas cerebrais já mapeadas nem sempre correspondem a representações funcionais uniformes ou precisamente delimitadas, podendo haver superposições funcionais. ...Algumas funções não ficam limitadas a fronteiras rígidas, como é o caso das funções cognitivas que dependem de amplas áreas do cérebro de conexões e associações entre elas. O processo de informação central também envolve os mecanismo atencionais, de memorização e afetivos relacionados á motivação. (CASELLA; AMARO JR, COSTA, 2011, p. 43).

A neuroplasticidade é a grande aliada do sistema cognitivo que rege a aprendizagem. Esta qualidade do cérebro de estabelecer circuitos variados de adaptação funcional ou estrutural do sistema nervoso permite a aquisição de conhecimento por indivíduos com lesões cerebrais.

A plasticidade cerebral durante o processo de aquisição da leitura provavelmente induz outras modificações no circuito neural envolvido com o aprendizado. Assim, as funções de memórias são armazenadas no hipocampo por semanas ou meses e através do processo de consolidação são transferidas e armazenadas no neocórtex temporal. 
Durante este processo, as modificações nas conexões neurais permitem que se aprenda a solucionar novos problemas. Isto é de extrema importância para a memoria, aprendizagem e outras funções simbólicas do cérebro demostrando a contínua plasticidade de alguns circuitos neurais com o aprendizado. Este processo é fortemente dependente de fatores neurobiológicos, genéticos e ambientais, familiares.

Deve-se enfatizar que mesmo na idade adulta há redistribuição das funções sensório motoras dependentes de treino. Assim, pacientes leitores com Braille, apresentam maior representação sensorial e motora para a área do dedo indicador (dedo utilizado na leitura) quando avaliados por estimulação magnética transcraniana (TMS do inglês transcranial magnetic stimulation) e potenciais evocados somatosensoriais. Em músicos de instrumentos de corda ou teclado foi evidenciado aumento do sulco do giro-pré-central como um correlato da expansão da área motora nestes indivíduos e inversamente relacionado à idade do inicio deste treinamento musical. Embora a macroestrutura do encéfalo seja relativamente constante, a complexa microestrutura pode ser significativamente modelada pelo ambiente antes do nascimento, durante o desenvolvimento do individuo e mesmo durante toda a sua vida (CASELLA; AMARO JR, COSTA, 2011, p. 48-49).

A perda do momento inicial mais propício para o desenvolvimento da capacidade de leitura e escrita determina que se procure, após esta faixa etária, resgatar este aprendizado com o desenvolvimento de certas habilidades dentro de um processo de aprendizado e reabilitação. Isto determina outro planejamento da estratégia de ensino estimulando a capacidade associativa e as habilidades de percepção e execução. (CASELLA; AMARO JR, COSTA, 2011 p. 69).

São estas capacidades de percepção e execução que busquei estimular em meus alunos.

No sentido da reabilitação para a alfabetização de que fala CASELLA; AMARO JR, COSTA (2011) meu trabalho seguiu o princípio humanístico de Reabilitação que preside as atividades do Hospital Sarah Kubitschek de Brasília. Campos da Paz Junior o criador e diretor desta eficiente rede de hospitais assim define a função da reabilitação "os médicos julgam os doentes a partir do que a doença lhes fez perder; o que deixou de existir. A verdadeira reabilitação avalia o doente pelo que lhe restou, pelo seu potencial, por onde há espaço para investir” (Campos da Paz, 2007).

Entretanto não resisto e cito parte do artigo escrito por Campos da Paz porque sua postura humanística é revitalizadora.

Existe uma dicotomia que contribui perversamente para impedir a reabilitação de pessoas que apresentam alguma forma de incapacidade sejam reabilitadas: os médicos julgam os doentes a partir do que a doença lhes fez perder; o que deixou de existir. 
A verdadeira reabilitação avalia o doente pelo que lhe restou, pelo seu potencial, por onde há espaço para investir. Essa visão aparentemente ingênua tem velhas raízes: reporta-se às origens da medicina. Historicamente, a reabilitação é recente. Podemos localizar sua origem com alguma precisão a partir da II Guerra Mundial quando milhares de pessoas se viram privadas de algo absolutamente essencial: a capacidade e o arbítrio de ir e vir.

Paralelamente, formou-se uma sociedade consumista, altamente preconceituosa, que busca parâmetros de perfeição dissociados da realidade, esquecendo que é a diversidade que caracteriza a natureza e o homem. E a incapacidade é uma forma particular de diversidade.

Preconceitos nascidos dessas circunstâncias segregam quem foi privado de alguma função, seja motora, seja intelectual, em guetos hospitalares, como no passado foram segregados quem os regimes totalitários consideravam "imperfeitos".

Mesmo antes disso, a literatura já tinha o mau hábito de associar a vilania de alguns personagens a diferenças físicas, particularmente aquelas vistas como deformações. (Campos da Paz, 2007)

$\mathrm{Na}$ reabilitação para a alfabetização através da ativação da percepção sempre tive em mente o desenvolvimento não apenas da percepção ocularcentrista, mas da percepção total, de todo o corpo, visual, kinetica, tátil, espacial, gustativa.

Olfato-visão-paladar-audição e tato misturam-se e são o que Merleau-Ponty chamou de "simbólica do corpo", onde todas as relações de sentido são estabelecidas em um contexto humano, como um "corpo" de significações e não a soma de significações apreendidas por canais específicos. (Hélio Oiticica em Braga, 2011, p. 264).

Faltou explorar o olfato que os artistas hoje tem incluído em seus trabalhos, como Josely Carvalho em sua última exposição no Rio de Janeiro (2011) e Carsten Holler em exposição no New Museum of Contemporary Art de New York (2011).

A percepção visual sempre foi mais valorizada pela filosofia que a percepção corporal por ser considerada mais intelectual desde Platão. A percepção corporal era até temida por distorcer através de sentimentos e emoções a razão. A arte/educação modernista colocava a visão e a audição como os sentidos privilegiados. Foi o pós-modernismo, tendo como antecedente Merleau-Ponty, que aclamando a arte relacional, a arte comprometida com a vida e com outros seres humanos, estendeu o sentido da percepção para além do visual comprometendo o sujeito, seu corpo, seu movimento no espaço, seu contato com outros seres humanos na função perceptual. 
Hélio Oiticica corroborava com a ideia de que a visão não era suficiente para abarcar o poder transformador da Arte.

"Para transformar comportamento, apelar apenas para a visão não seria suficiente. Comportamento e pensamento caminham juntos e pensamento se faz com o corpo todo, não apenas com os olhos". (Helio Oiticica apud Braga, 2011, p. 264)

Comportamento para ele era um conceito que significava forma de existir criativamente.

$\mathrm{O}$ ver que procuro desenvolver em meus alunos abarca todos os sentidos, é um ver que desenvolve o comportamento criativo sem que isto seja uma obrigação, desenvolve a inteligência e a capacidade de múltiplas formas de pensar como diz David N. Perkins no livro The Intelligent Eye:Learning to think by looking at Art (1994):

first of all, looking at art requires thinking art must be 'thought through' The prow of the Tanimbarese boat needs long and thoughtful look, no just the passing glance,to begin to understand its message and savor its elegance.

Second,thoughtful looking at art has an instrumental value.It provides an exelent seting for the development of better thinking,for the cultivation of what might be called the art of intelligence.We can learn to use our minds better by thoughtful looking at the prow of a Tanimbarese boat -and many other things. 'Thinking through looking' thus has a double meaning:

The looking we do should be thought through,and thoughtful looking is a way to make thinking better. (PERKINS, 1994, p. 3).

Encerrando este trabalho gostaria de dizer que enquanto escrevia esta tese pessoas que conhecem as ansiedades de um doutorado tentaram me convencer a escrever em lugar da tese um livro pois o título de doutora que eu poderia obter não vou usar porque jamais passaria nos exames de saúde que são feitos para ingresso na carreira docente. Entretanto as baixas estatísticas de escolaridade dos deficientes me obrigaram a persistir no intuito de flexibilizar a Universidade para a aceitação das limitações e potencialidades dos deficientes. Flexibilizar não significa mediocrizar, mas a possibilidade de considerar diferentes discursos expositivos e /ou demonstrativos de ação, reflexão e pesquisa.

24,6 milhões de brasileiros $(14,5 \%)$ possuem algum tipo de deficiência. Apenas $2 \%$ deles têm emprego formal. 51,3\% das pessoas com deficiência têm até três anos de estudo.

$78,7 \%$ não concluiram o ensino médio. Apenas 1,6\% tem mais de 12 anos de estudo." (Revista Cidadania Novembro /Dezembro, 2011, p. 7) 
Desta estatística se pode concluir que só $1,6 \%$ ou menos de deficientes chega à universidade, imaginem a um doutorado.

$28 / 12 / 2011$

PONTO FINAL!

CHEGA! ACABOU!

QUER DIZER, FALTA UNS ARREMATES, MAS O GROSSO TAH PRONTO!

QUE VIAGEM! TIVE QUE VOLTAR À 2007 VARIAS VEZES

E ALGUMAS DESSAS VEZES FOI DOLOROSO (http://amaliabarbosa.zip.net) 


\section{BIBLIOGRAFIA CITADA}

BARBOSA, Ana Mae. Arte-Educação: conflitos-acertos. São Paulo: Editora Max Limonade, 1984.

A imagem no ensino da Arte. SP: ED. Perspectiva, 2009.

e CUNHA, Fernanda P. Abordagem Triangular no ensino das Artes e Culturas Visuais. SP; ED Cortez, 2010.

ARAUJO, Aloisio (Org) Aprendizagem infantil: uma abordagem da neurociência, economia e psicologia cognitiva. Rio de Janeiro: Academia Brasileira de Ciências e Fundação Conrado Wessel, 2011.

BATEZAT, Maria Lúcia. Desenho Infantil e Seu Ensino a Crianças Cegas Razões e Método. Curitiba: Editora Insight, 2011.

BRAGA, Paula. "Conceitualismo e Vivência” em BRAGA, Paula. (Org.). Fios Soltos: A Arte de Hélio Oiticica. São Paulo: Perspectiva, 2011. pp. 259-287.

CAMNITZER, Luis. (Texto original de 2009). "Art and Literacy” em ALLEN, Felicity, Education. Londres Whitechapel Gallery, 2011. pp. 108-110.

CAMPOS DA PAZ JUNIOR, Aloysio. Jornal O Globo, segunda feira, 25 de junho de 2007.

CASELLA, Erasmo Barbante; AMARO JR, Edison COSTA, Jaderson Costa da. "As bases neurobiológicas da aprendizagem da leitura" em ARAUJO, Aloisio (Org.). Aprendizagem infantil: uma abordagem da neurociência, economia e psicologia cognitiva. Rio de Janeiro: Academia Brasileira de Ciências e Fundação Conrado Wessel, 2011. pp. 37-69.

CSIKSZENTMIHALYI, Mihaly and ROBINSON, Rick. The Art of Seeing: an interpretation of the aesthetic encounter. California: A joint publication of the J. Paul Getty Museum and the Getty Center for Education in the Arts.1990.

DEWEY, John. Arte como Experiência. São Paulo: Ed. Martins Fontes, 2010. A $1^{\text {a }}$ Edição em inglês é de 1934.

FAZENDA, Ivani. Interdisciplinaridade: História, Teoria e Pesquisa. Campinas SP, Papirus Editora, 1994.

FEUERSTEIN, Reuven

http://www.cursosadistancia.pro.br/teorias_aplicadas/cursos_a_distancia_reuven_feuerstein.htm Acessado dia 15 dez. 2011 as 16:16. 
FUNDAÇÃO BUNGE Revista Cidadania Novembro /Dezembro, 2011 Edição 63 ano 8 São Paulo

GARCIA, Mauricio Koprowski. Depoimento a Ana Amália Barbosa em 2008.

GREEN, Dr

http://www.ehow.com/about_5266377_should-teachers-cerebral-palsy.html

Acessado no dia 07 nov. 2011 as 14:15.

KLEIN, Yves. http://www.dailyartfixx.com/tag/yves-klein/

Acessado no dia 19 dez. 2011 as 15:20.

LANGER, Susane. Sentimento e Forma. São Paulo: Ed. Perspectiva, 1980.

MARIN, Ricardo and ROLDAN, Joaquin "Photo essays and photographs in visual arts -based education research" in International Journal of Education Through Art. Vol. 6 Number 1, 2010, p. 3-20.

MELLO NETO, João Cabral, Museu de tudo. Rio de Janeiro: Editora José Olympio, 1975.

NITRINI, Ricardo, BACHESCHI, A. Luiz, A Neurologia que todo médico deve saber. São Paulo: Maltese e Livraria e Editora Santos, 1997.

PEIXOTO JUNIOR, Carlos Augusto. "Sobre o corpo social como espaço de resistência e reinvenção subjetiva" em s/d Lugar Comum $\mathrm{N}^{\circ}$ 21-22, pp. 57-72

http://www.universidadenomade.org.br/userfiles/file/Lugar\%20Comum/21

22/09\%20SOBRE $\% 200 \% 20$ CORPO $\% 20$ SOCIAL $\% 20$ COMO $\% 20$ ESPACO $\% 20 \mathrm{DE} \% 20 \mathrm{RESIS}$

TENCIA\%20E\%20REINVENCAO\% Consultado dia 20 dez. 2011 as 20:59

PERKINS, David N. The Intelligent Eye: Learning to think by looking at Art. Santa Monica: The J. Paul Getty Trust and Harvard Project Zero, 1994.

PILLAR, Analice Dutra. "Leitura e releitura", em Analice Dutra Pillar (Org.). A educação do olhar no ensino das artes. Porto Alegre: Ed Mediação, 1999. pp. 7-19.

REED, Umbertina Conti. "Encefalopatia não progressiva da infância ou paralisia cerebral” em Ricardo Nitrini e Luiz A. Bacheschi. A Neurologia que todo médico deve saber. São Paulo: Maltese e Livraria e Editora Santos, 1997. pp. 305-315.

FUNDAÇÃO BUNGE Revista Cidadania Novembro/Dezembro, 2011. Edição 63, ano 8. São Paulo

SIMAS, Cláudia Gunzburger. Janelas expressivas em BARBOSA, Ana Mae, AMARAL, Lilian. Interterritorialidade mídias, contextos e educação. São Paulo: Editora Senac e Sesc SP, 2008. pp. 135-155. 
SPERLING, David. "Corpo+Arte=Arquitetura" em BRAGA, Paula. (Org.). Fios Soltos: A Arte de Hélio Oiticica. São Paulo: Perspectiva, 2011, pp. 117-146.

STOKROCKI, Mary. "Um dia escolar na vida de uma menina Navajo: Estudo de caso em forma de conto oral etnográfico" em BARBOSA, Ana Mae (Org.). Arte-Educação: leitura no subsolo. São Paulo: Editora Cortez, 2008. pp. 159-174.

TREND, David. Cultural Pedagogy: Art/Education/Politics. New York; Westport, Connecticut; London: Bergin \& Garvey, 1992.

ZIMMERMAN, Enid "Avaliação autêntica de estudantes de Arte no contexto de sua comunidade" em BARBOSA, Ana Mae (Org.). Arte/Educação contemporânea: consonâncias internacionais. São Paulo: Editora Cortez, 2008. pp. 404-420.

WEBER, Suzi. V reunião científica de pesquisa e pós-graduação em artes cênicas Departamento do Teatro da UFRGS http://www.portalabrace.org/vreuniao/textos/pesquisadanca/Suzi\%20Weber\%20\%20Corpo\%20social,\%20corpo\%20dan\%E7ante.pdf consultado em 19 dez. 2011 pp. 21-23. 